James William CORNISH

\title{
CONSTRUCTION SAFETY LAW
}

Submitted for the degree of Master of Laws at the Victoria University of Wellington

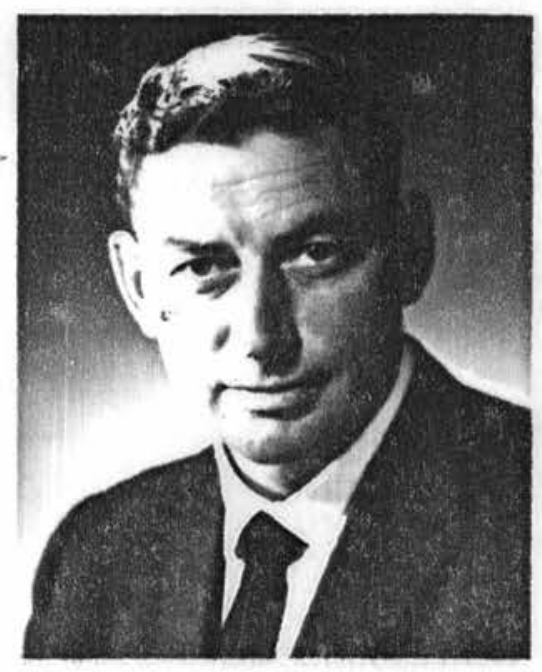

October, 1979 


\section{THESIS ABSTRACT}

The development of industrial safety law in Britain and New Zealand and the origins of construction safety law are outlined in Part I. The administration and interpretation of the Construction Act 1959 are described in Part II, and Part III highlights the comparable statute law in three Commonwealth countries.

The thesis will assist persons engaged in industry, lawyers and departmental officers in the understanding of the law and its application to construction work. The information. presented on overseas law will assist those involved in the task of reviewing and consolidating the New Zealand industrial safety, health and welfare legislation.

The history of the British Factories Acts leading on to the Health and Safety at Work Act 1974, described in Chapter 1 , highlights the importance of a self-regulating, integrated statutory system and a professional inspectorate with an advisory role and residual enforcement powers. New Zealand safety law has developed as the country's industrial needs have determined, as will be seen from Chapter 2. Generally, British statutes have been adopted, but construction safety law is the exception and Chapter 3 shows that, from the earliest Bill introduced by Richard John. Seddon in 1892 up to the present, the legislation covering the construction industry has been initiated and drafted with industry representation.

The more empirical subjects such as current policy and practice, sanctions, codes, education, other legislation and reform, as well as the purpose, effect, extent and application. of the Construction Act 1959 are discussed in Chapter 4. The results of the author's legal research and analysis are contained in Chapters 5 and 6 under the headings of 'Liabilities' and 'Technical Law'. The responsibilities of employers, workmen, safety supervisors, inspectors and the Crown are set out and explained in terms of the statute and the interpretation. from the case law. The technical subjects include scaffolding, guardrails, brittle roofing, fall of objects, access, excavations, mechanical plant, demolition, eye protection, asbestos, work in compressed air, health and welfare. 
Chapters 7,8 and 9 examine the present legislation in Britain, Australia and Canada and indicate a trend towards a unified approach to occupational safety, health and welfare and one enactment for all places of work, and with separate regulations and codes of practice for each industry.

This study has been carried out by the present Chief Safety Engineer of the Department of Labour who has been responsible for the administration of the Construction Act 1959 since 1968.

A separately bound appendix includes a copy of the Construction Act 1959 and the Amendments (Appendix A), the Inspection of Building Appliances Bill 1892 (Appendix B), the Scaffolding Inspection Act 1906 (Appendix C), the Tasmanian Industrial Safety, Health and Welfare Act 1977 (Appendix D), the Ontario Occupational Health and Safety Act 1978 (Appendix $E)$, and copies of the unreported judgments and decisions referred to in the thesis (Appendix F). 


\section{ACKNOWLEDGEMENTS : -}

I express my appreciation and thanks to Professor D. L. Mathieson, B.C.L. Oxford, B.A, LL.B, LL.D, who has patiently guided and encouraged me in this work, to Mr G. L. Jackson, A.Prof., Secretary of Labour, for permission to undertake the study, and to the engineers and administrators in the overseas countries for the information supplied.

J. W. Cornish, LL.B, D.P.A. 


\section{CONTENTS}

PART I

DEVELOPMENT OF INDUSTRIAL SAFETY LEGISLATION

Chapter 1 ... Britain

2 ... New Zealand

3 ... N.Z. Construction Safety Law

PART II

ADMINISTRATION AND LAW

Chapter 4 ... Implementation and Policy

5 ... Liabilities

6 ... Technical Law

PART III

OVERSEAS LAW

Chapter 7 ... Britain

8 ... Australia

9 ... Canada 


\section{ILLUSTRATIONS}

Lord Ashley

Leonard Horner

Right Hon. R.J. Seddon

Hon. W.P. Reeves

Edward Tregear

D.I.C. Scaffolding Collapse

Compressed Air \& Underwater Codes

Excavation \& Scaffolding Codes

Construction Act \& Safety Guides

Humber Bridge Tower, Britain

West Gate Bridge, Australia

CN Tower, Canada

Comparison of Statutes

\section{$\underline{\text { Page }}$}

$5 a$

$5 b$

11

$11 \mathrm{a}$

$11 \mathrm{~b}$

$21 a$

$40 a$

$68 a$

$84 a$

$89 a$

$99 a$

$111 \mathrm{a}$

$112 \& 113$

(Photographs: courtesy of the General Assembly Library) 

Anns V. London Borough of Merton [1977] 2 Al1 E.R. 482 (H.L.)66 Atkinson V. Sir Alfred McAlpine Ltd. (1974) 16 K.I.R. 22083 Austr. Mutual Prov. Soc. V. Allan (1978) 52 A.I.J.R. $407 \quad 42$ Austr. Paper Manuf. Lta. v. Conyers [1962] N.S.W.R. 44978 Bailey v. Ayr Engr. Ltd. [1958] 2 All E.R. 222 (C.A.) 76 Baker v. F. Rende11 Ltd. [1970] 3 All E.R. 442 Barlow v. Fletcher Constr. Ltd. [1963] N.Z.L.R. 952 Blenkiron v. Gr. Central Gas. Co. (1860) 2 F. \& F. 437 Boyle v. Kodak Ltd. [1969] 2 All E.R. 439 (H.L.) 57, 71 Boyton. v. Willment Bros. Ltd. [1971] 3 All E.R. 634 (C.A.) 82 Byers v. Head Wrightson Lta. [1961] 2 All E.R. 538 (Q.B.D.) 70 Byrne v. E.H. Smith (Roofing) Ltd. [1973] 1 All E.R. 490 (C.A.)

Cain v. Doyle (1946) 72 C.I.R. 408 (H.C.A.)

Canadian Broad. Corp. V. A.G. Ont. (1959) 16 D.L.R. (2d) 609

Caswell v. The Corp. of Sault. (unreported S.C. Can., 1978) 60 Chatfield v. Sth. Brisb. Gas Co. [1969] Q.W.N. 45

(Q. Sup. Ct.)

Cork. v. Kirby Maclean Ltd. [1952] 1 All E.R. 1064 (Q.B.D.) 70 Cummings v. Sir W. Arrol Ltd. [1962] 1 Al1 E.R. 623 Dixon v. Cementation Co. [1960] 3 All E.R. 417 Donaghey v. Boulton Ltd. [1967] 2 All E.R. 1014 (H.L.) 75 Donoghue v. Stevenson [1932] A.C. 562 (H.L.) 66 Driver v. W. Willett Ltd. [1969] 1 All E.R. 66567 Dutton v. Bognor Regis U.B. Co. [1972] 1 All E.R. 462 (C.A.) 66 Duyvelshaff v. Cathcart_Ltd. [1973] 1 A.L.R. 125 (H.C.A.) 71 Eggers v. E.D. Wilson Constr. Ltd. [1974] N.Z.L.R. 901 Electrical P.T. Ltd. V. Robinson (1973) 2 Q.L. 329 Ferguson v. John Dawson Ltd. [1976] 3 Al1 E.R. 817 (C.A.) 42, 72 Field v. Perrys (Ealing) Ltd. [1950] 2 All E.R. 521 Garner v. John Thompson Ltd. (1968) 6 K.I.R. 1 (C.A.) 72 Gill v. Donald Humerstone Ltd. [1963] 3 All E.R. 180 (H.L.) 73 Grays Haulage Co. v. Arnold [1966] 1 All E.R. 896 Hargreaves v. Mayhead Bros. Ltd. [1971] N.Z.L.R. $559 \quad 42,43$ H. B. Farmers Lta. v. Saf. Insp. (unreported 12.9.68) 50 
H. Buckman Ltd. V. Flanagan (1974) 4 A.I.R. 465 (H.C.A.) 57

Hedley Byrne Ltd. v.Heller Ltd. [1964] A.C. 465 (H.L.) 66

Hobbs V. C.G. Robertson Ltd. [1970] 2 All E.R. 347 (C.A.) 82

Home Office v. Dorset Yacht Co. [1970] A.C. 1004 (H.L.) 66

Insp. of Fact. v. MLD. Timber Co. [1965] N.Z.I.R. 613

Insp. of Scaff. V. Aughton (1957) 9 M.C.D. 163

Insp. of Scaff. v. Rush \& Taylor (1923) M.C.R. 25

Jennings $v$. Norman Collison Ltd. [1970] 1 A11 E.R. 1121

(C.A.)

77

Kel1y v. Pierhead Ltd. [1967] 1 Al1 E.R. 657 (C.A.) 72

Kirkpatrick v. Lewis Constr. Ltd. [1964] V.R. 515 (Vict. Sup. Ct. )

80

Knight v. Demolition Co. [1953] 2 All E.R. 508

81

Lambert v. Thiess Bros. Ltd. (1965) 84 W.N. (Pt. 1 )

$$
\text { (N.S.W.) } 97
$$

Lim Chin Aik v. Reginam [1963] 1 All E.R. 223

Littler $v \cdot$ G.L. Moore_Ltd. [1967] 3 All E.R. 801

Loverlidge v. Anselm olding Ltd. [1967] 1 All E.R. 459

(Q.B.D. )

80

McArdle V. Andmac Roofing Co. [1967] 1 All E.R. 583 (C.A.) 75

McAuliffe v. Fletcher Constru. Co. [1970] N.Z.L.R. 680

Machray V. Stewarts \& Lloyds Ltd. [1964] 3 A11 E.R. $716 \quad 46$

Manukau C.C. v. Saf. Insp. (unreported 28.2.79)

44,55

Manwaring v. Billington [1952] 2 AllE.R. 747

46

Merlino V. Austr. Meat_Board (1943) 45 W.A.L.R. 12

(W.A. Sup. Ct.)

Moloney v. A. Cameron [1961] 2 All E.R. 934 (C.A.)

Moorcroft v. Thomas Powles_Ltd. [1962] 3 All E.R. 741

(Q.B.D.)

74

Moore v. Concast Ltd. [1972] 2 N.S.W.L.R. 687 (N.S.W. Ct. of $\mathrm{App} \cdot \cdot$ )

Mortimer v. S.B. Allison Ltd. [1959] 1 All E.R. 567 (H.L.) 81

New P1y. Boro. v. Rope Constr. Co. (1962) 10 M.C.D. 447

Nielson $v \cdot$ P.J. Lowther Ltd. [1971] Qd. R. 92 (Q. Sup. Ct.) 71

o'Brien V. U.D.E.C. Ltd. (1968) 4 K.I.R. 449 (C.A.) 71

Phillips v. Robertson Thain Ltd. [1962] 1 All E.R. 527

(Q.B.D.)

74

Queen V. Pierce Fisheries (1970) 5 C.C.C. 193 (S.C. of Can) 59

Ransom \& Daniels v. McAlpine Ltd. (1971) 15 K.I.R. 141

Ready Mixed Concrete $v$. Minister of Pensions [1966] 1 All

E.R. 433 
Regina v. Amherst Cranes Ltd. (1975) 26 C.C.C. (2d) 477

Regina v. A.O. Pope Ltd. (1972) 20 C.R.N.S. 159

Regina v. Greening Ltd. [1968] 1 0.R. 759

Regina v. PPG Industries (unreported 15.6.78 - Sak. Mag Ct) 59

Regina v. Sam Consentin Ltd. [1965] 2 0.R. 623

59

Regina v. Strand Electric Ltd. [1969] 1 0.R. 190

49

Regina v. V. K. Mason Constr. Ltd. [1968] 1 0.R. 399

59

Regina v. Westeel-Rosco Ltd. (1975) 27 C.C.C. (2d) 467

52

Rice v. Henley (1914) 19 C.L.R. 19 (H.C.A.)

73

Rigter v. J.C. Taylor Constr. Ltd. (1974) 9 S.A.S.R. 28274

Ross v. Assoc. Cement Ltd. [1964] 2 All E.R. 452 (H.I.)

45,46

Saf. Insp. V. A.F. Burdon Ltd. (unreported 24.1.79)

47

Saf. Insp. v. A.G. Hall (unreported 23.11.77)

Saf. Insp. v. Archer Building Ltd. (unreported 7.10.65)

45

Saf. Insp. V. Auckland Reg. Auth. (1978) 14 M.C.D. 163

41

Saf. Insp. V. A. Williams Constr. Ltd. (unreported 4.9.64) 53

Saf. Insp. v. A. Williams Constr. Ltd. (unreported 29.3.65) 49, 51

Saf. Insp. v. Civil \& Civic Ltd. (unreported 15.12.76) 51

Saf. Insp. v. Commercial Concrete Ltd. (unreported 26.7.73) 61

Saf. Insp. v. Fraei \& Edgar Ltd. (unreported 30.5.72) 75

Saf. Insp. v. Madder \& Bourne Ltd. (unreported 6.10.70)

Saf. Insp. V. M.J. Carroll (unreported 27.7.73)

58

Saf. Insp. v. Plastercraft Ltd. (unreported 7.9.78)

49

Saf. Insp. V. Poverty Bay Power Bd. (unreported 24.11.78) 50

Saf. Insp. v. Russe11 Pemberton Ltd. (1979) 14 M.C.D. 34479

Saf. Insp. v. Special Coatings (N.Z.) Ltd. (unreported

$$
23.3 .79 \text { ) }
$$

61

Saf. Insp. V. V.A. Draper Ltd. (unreported 25.2.66) 84

Saf. Insp. v. Wellington City Council (unreported 13.3.79) 50

Sherras v. De Rutzen [1895] 1 Q.B. 918

54

Sexton_v. Scaffolding (G.B.) Ltd. [1952] 2 All E.R. 1085 (C.A.)

Singh v. Vange Scaffolding Ltd. (1969) ? K.I.R. 101

Smith v. George Wimpey Ltd. [1972] 2 All E.R. 723 (C.A.) 78

Smith v. Vange Scaffolding Ltd. [1970] 1 All E.R. 249

Southland Acclim. Soc. v. Anderson [1978] N.Z.L.R. $838 \quad 63$

Stevenson, Jordan \& Harrison Ltd. v. Macdonald [1952]

1 T.L.R. 101

Sweet v. Parsley [1970] A.C. 132 (H.L.)

Tanti v. L.L. Constr. Ltd. (1972) 20 F.I.R. 10 
Trott v. W.E. Smith (Erectors) Ltd. [1957] 3 All E.R. 500 (C.A.)

Upton v. Hipgrave Brothers [1965] 1 All E.R. 6 (Q.B.D.) 76 Walker v. Bletchley Fleltons [1937] 1 All E.R. 170

Warner v. Metropolitan Police [1969] 2 A.C. 256 (H.L.) 55

Westcott v. S.\& \&. Engineers_Ltd. [1960] 1 All E.R. 775772 Wilkins \& Davies Constr. Co. v. A.F. Burdon (unreported 9.7.79) 48

Woods v. Power Gas Corporation (1969) 8 K.I.R. 834 (C.A.) 77 Zajackowski v. S.M.H.E. Auth. (1968) 1 N.S.W.R. 710 (N.S.W. C. of A.) 


\section{$\underline{\text { PART I }}$}

\section{DEVELOPMENT OF INDUSTRIAL SAFETY LEGISLATION}

1. Britain

Safety, Health and Welfare are recognised as three separate but interrelated subjects. A reasonable standard of all three is required in modern industrial undertakings. This was not so in Britain in the early days of the industrial revolution. Working conditions in factories and mines from the middle of the 18th century to the middle of the 19th century were appalling. The British reformers and legislators tackled the subject of welfare first because the excessive hours and the lack of facilities called for immediate attention.

\subsection{The Textile Industry: These atrocious working} conditions originated in the textile manufacturing mills. Until 1733, when John Kay invented the 'flying shuttle', all was well because the textile trade had been essentially a domestic industry, with the two main processes, spinning and weaving, being carried on by family members. But as the mechanical aids were invented, and particularly after 1785 , when Edward Cartwright produced the first powered loom, working patterns changed dramatically. Children as well as adults were hired for 14 or 15 hours a day 6 days a week to work in cramped and unnatural positions to attend the new machines. As mechanization developed a vast flow of capital was attracted to the industry and the successful mill owners quickly became wealthy entrepreneurs. There emerged a generation of ruthless masters who wielded enormous power but who lacked in human scruples. They cared little, if at all, for the welfare, health or safety of their workforce. The children who survived grew up with deformed bodies, crooked legs and twisted shoulders. Serious epidemics broke out in many of the factories due to inadequate ventilation and the filthy working environment.

\subsection{The 1802 Act: The first attempt to improve this} situation was the passing of the "Health and Morals of Apprentices Act 1802", (42 Geo. 3, C.73). This Act applied to the cotton and woollen mills and factories in which more than 2 apprentices, or more than 20 other persons, were employed but in practice it was restricted to the textile industry. 
Under the Act the mills were to be limewashed, and open windows fitted to ensure adequate ventilation. Apprentices were to be clothed by the employer, and their hours of work reduced to 12 per day between $6 \mathrm{a} . \mathrm{m}$. and $9 \mathrm{p} . \mathrm{m}$. The sleeping apartments of males and females were to be separated and apprentices were not to be slept more than 2 to each bed.

Unpaid factory 'visitors' were appointed by the local magistrates to inspect the mills but they had no incentive, or enthusiasm, to take any action to enforce the provisions. Although the practical results of the 1802 Act were negligible, it was an important constitutional step, because it was the first intrusion of the state into the arena of industrial controls, and the first factories Act anywhere in the world.

Three other Acts were passed in 1819, 1825 and 1829 but they were also ineffective mainly because of the failure of the voluntary inspector scheme.

\subsection{The 1833 Act: A Royal Commission was appointed in} 1833, primarily on the instigation of Lord Ashley (afterwards famous as Lord Shaftesbury), to inquire into the working conditions in the factories. Evidence was produced of children still working for 15 hours a day for very low wages and whole families working together, the parents being unable to protest at the maltreatment of their children for fear of losing their jobs. Safety standards did not exist and there were numerous instances of deformity, stunted growth and unnecessary fatalities and injuries caused by dangerous machinery and an absence of care and supervision.

From the beginning of the 19th century until the $1840 \mathrm{~s}$ Britain was economically depressed and unemployment was widespread and thus reform was difficult to implement. However, the legislature after receiving the report of the Royal Commission immediately passed the fifth Act (The Factories Act 1833). This Act was an outstanding milestone in the history of industry in that it provided for the first full-time factory inspectors. The other provisions of the Act resembled its predecessors in that it dealt only with welfare matters and contained no safety requirements.

The four inspectors appointed, quickly became aware of the magnitude and the nature of the accident problems that were 
being caused by unguarded machinery and dangerous accessways. These first inspectors were intelligent, dedicated and farsighted men and although they faced bitter and sustained opposition from the mill owners, and even some of the workers themselves, history shows that it was to them that the successful development of industrial control, with its ever widening ramifications, was due.

\subsection{The First Safety Law: In 1841 the four inspectors each} prepared a report for the Home office and each recommended that safety legislation be introduced. The most renowned of these inspectors, Leonard Horner, included in his report that the person in the best position to prevent accidents was the man directly in charge of the workforce. (The author is convinced that this concept still applies today and that, for hazardous work, safety control must be retained by line management with the foreman being in the key position.)

Later in 1841 a committee under the chairmanship of Lord Ashley recommended that dangerous machines be fenced and that the cleaning of moving parts be prohibited. This led to the Factories Act 1844 which included these safety provisions.

It can be argued, however, that the first Act to include safety was the Coal Mines Act 1842 which contained a section. prohibiting any person under 15 or over 50 from acting as an. engine-man on a hoist. Prior to this children had been employed on these machines and accidents were frequent.

Back in the factories great controversy raged over the fencing of machinery provisions in the 1844 Act and the reactionaries were able to turn development back a few years. The Factories Act 1856 relaxed these fencing requirements to some extent, but they were fully restored and extended by 1867 . This was the only retrograde step in a continuous improvement of safety standards up to the present day, and most of the 14 Factories Acts passed since the 1844 Act have included additional safety requirements of one kind or another.

Some of the non-textile factories were brought within the scope of the law in 1864 and 1867 including iron foundaries, printing works and associated industries, and the Factory and Workshop Act 1878 included practically all the remaining 
manufacturing undertakings. An amendment Act in 1891 gave the Home Secretary power to make special regulations for dangerous trades, and the Factory and Workshop Act, 1901 set further standards for ventilation, heating and machine safety.

1.5 The 20th Century: One of the main features of Factory Act development this century has been the 'notional factories'. This concept broadened the scope of the Acts to cover industries such as construction. which are technically not factories. In 1904 safety regulations were made to cover work on docks, wharves and quays, in 1914 for shipyards, in 1926 for certain building sites, in 1948 for all building sites, and in 1961 for works of engineering construction.

The Factories Act 1937 was the first major consolidation. in the 20th century, and the basic requirements of this Act are still in force today. Minor additions were made in the amendment Acts of 1948 and 1959. The present statute, the Factories Act 1961, is largely based on the 1937 Act.

\subsection{The Factory Inspectorate: Alexander Redgrave, an} outstanding inspector, was appointed as clerk to the original 4 inspectors in 1844, and became a sub-inspector in 1847, an inspector in 1852, and the first Chief Inspector in 1878. He held that office until 1891. In 1880 he reported that:

"It has been my view always that we are not acting as policemen and that it is our object to be friend of the manufacturer as much as the friend of the employee. It has been my endeavour, since I have had anything to do with factory administration, that we should explain the law, and that we should do everything we possibly could to induce them to observe the law, and that a prosecution should be the very last thing that we should take up."

This policy of persuasion and conciliation has continued throughout the inspectorates, and it has become a tradition of industrial inspectors throughout the Commonwealth. Enforcement powers have always been reserved for those few occasions when all other means have failed.

\subsection{The Robens Report: The British safety and health}

legislation came under increasing criticism in the 1960 s mainly due to the plethora of Acts and regulations governing each industry which presented problems of definition, overlapping jurisdiction and duplication of inspection. In 1969 a Royal Commission was set up under the chairmanship of Lord Robens 
to examine all facets of industrial health and safety. This Commission reported in 1972, (Cmnd. 5034). It stated that the law had assumed an "unnecessary complexity and superfluity" and that much of it was "unsatisfactory and unintelligible". It recommended the institution of a unified statutory framework applying to all workplaces and that full responsibility be placed upon management in respect of the total employment environment extending not only to the safety of employees but also to the public. It stated that the employee's duty should extend to taking care of himself, his fellow workers and other persons in the vicinity. The Commission also emphasised the point that had been made for many years that safety could not be achieved through the agency of an inspectorate intent on enforcement. Safety it concluded was an essential function of good management.

1.8 The 1974 Act: The Health and Safety at Work etc. Act, 1974 followed closely the recommendations of the Robens Report. The Act lays down the general legal obligations of all concerned in one single enactment with the enforcement under the control of a unified administration. Most of the old law (e.g. The Factories Act 1961 and The Offices, Shops and Railways Premises Act 1963) remain in force but will be progressively repealed and replaced by regulations and approved codes of practice.

Some fundamental conceptual changes have been made by the new legislation, the most important being that the Act applies to people and not to premises. It covers all employed persons except domestic workers, and applies to persons who are not employees if they are affected by industrial processes. Obligations are placed upon employers in their capacities as designers, manufacturers, suppliers and importers of articles and substances to ensure that these can be used in safety and without risk to health. There are a number of provisions designed to bring about a greater awareness by all concerned of the need to promote safety and health at work and thus provide the impetus to the self-regulatory scheme which the Robens Commission recommended. (See Chapter? for further detail.) 


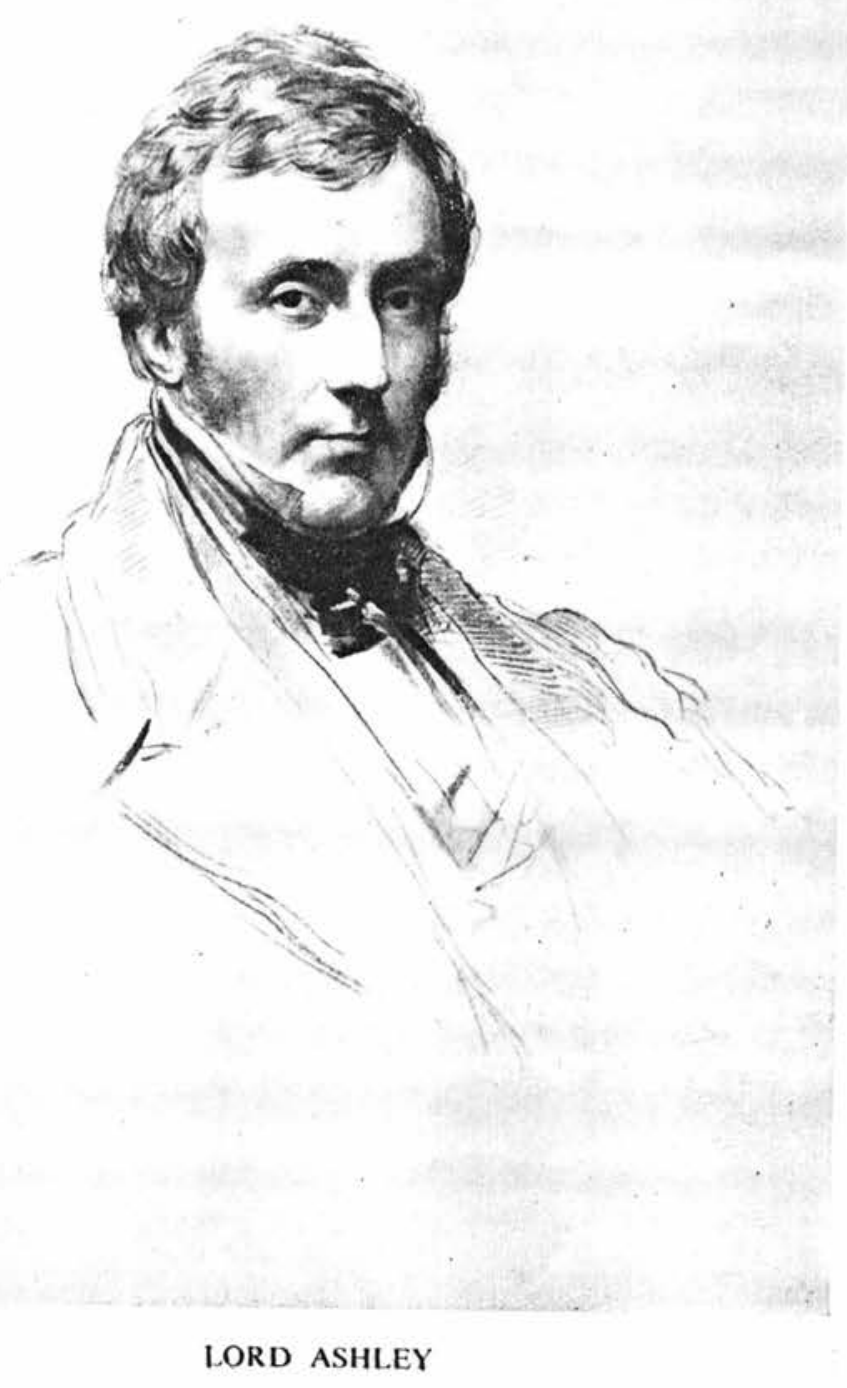




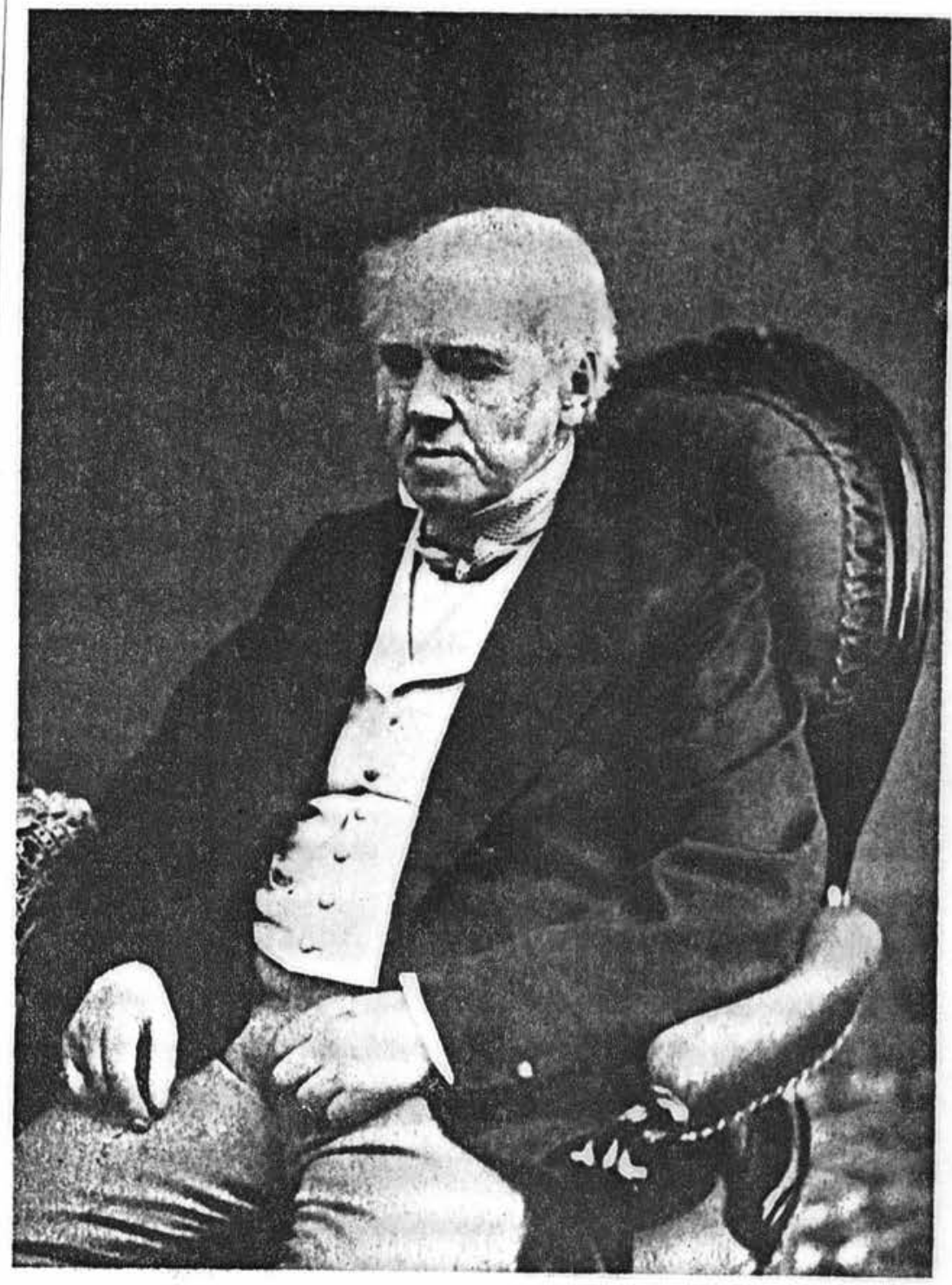

LEONARD HORNER 


\section{New Zealand}

2.1 The 1890's: The historians point to the nineties as the formative years of New Zealand's industrial legislation. Keith Sinclair describes the law passed in this decade as "the most progressive labour code in the world and the most comprehensive", and J. B. Conliffe considered that over this period there emerged "a code of labour legislation probably more complete and effective than then existed in any other country".

In December 1890 the Liberal-Labour party backed by the trade unions were swept into office on the pledge of improving the labour conditions which had been deteriorating throughout the 1880s. The utopia that the British immigrants had dreamed of had become a nightmare in these earlier years of depression. and the 'sweating' evil that existed in the homeland had begun to spread to the promised land. 'Sweating' or the 'putting-out' system were terms used for the sub-contracting of piece work usually carried out in the homes by family members compelled by economic necessity to work long hours for pittance payment. Unemployment and cheap labour had resulted from a global depression, the decline in gold-mining and the collapse of Vogel's public works programme. The entrepreneurs capitalised on the cheap labour market and in the towns small factories sprung up from the cottage industries. In trades such as tailoring women and children were required to carry out repetitive tasks and to tend primative machines crammed into shacks which soon became unhealthy and insanitory. Fortunately the growing trade union movement was able to expose these conditions before they deteriorated to the level that previously existed in the British factories. Thus the 'laissezfaire' policies of the 'continuous conservative government' of the 1870 s and 1880 s were no longer acceptable and state intervention to improve the lot of the unemployed and the working people became inevitable.

The Hon. W. Pember Reeves was appointed as the first Minister of Labour of the new 'Lib-Lab' Government and before 1895 he had piloted onto the statute books a number of industrial statutes including the highly successful Industrial Conciliation and Arbitration Act 1894. Working conditions improved considerably over the 1890 s not only as a result of 
these new laws and policies but also because New Zealand had begun to turn the economic tide and good times were streaming back with rising overseas prices.

2.2 The First Welfare and Safety Law: The history books leave an impression that New Zealand's labour laws originated in the 1890 era. This is because of the dominating influence of the I.C. \& A. Act which overshadowed the previous industrial law. However labour conditions had not been neglected in the earlier years in that the first statute, which was designed to improve the welfare of working women, was enacted as early as 1873. The Employment of Females Act 1873 was, like all the early legislation, modelled on the first British Acts. It prescribed a maximum of 8 hours work per day and holidays on Saturday afternoon, Sunday and public holidays and required workrooms to be properly ventilated. Amendment Acts were passed in 1874 and 1875, a consolidation in 1881 and further minor amendments in 1884 and 1885. These statutes however were generally not complied with and enforcement was inadequate.

The Dangerous Goods Act 1869 regulating the transport and storage of nitro glycerine, glonoine oil and petroleum, and the Explosives Act 1882, were the first New Zealand public safety statutes applying to industry. Another early development of significance encouraging accident prevention was the Employers' Liability Act 1882 which provided means for compensation for injured workers.

The first industrial safety statute was the Inspection of Machinery Act 1874 requiring machines to be fenced, boilers inspected and the prohibition of children on the operation. and maintenance of machinery.

A 'Factories Inspection' Bill of 3 short clauses was introduced into the House of Representatives in 1885 but it was not passed because of the non state interference policy of the 'continuous ministry' Government. In its last parliamentary session, however, this conservative administration had been forced into appointing a Royal Commission on labour conditions. The majority of this Commission found that no 'sweating' existed in New Zealand but the minority produced a vigorous report in which the evils of the system were obviously apparent. The Commission members were in full agreement that government 
intervention was now necessary and within a few weeks of receiving the report the Hon. Mr. Hislop introduced a "Factories and Shops" Bill requiring minimum sanitary conditions, inspection and registration of factories and restriction of hours of work. In speaking to the Bill on the 22 nd of $\mathrm{July}$ 1890 in the House Mr. Hislop said:

"... almost every clause in the Bill has been taken from the Acts in force in England, or from the Victorian Act. In fact, with regard to legislation of this sort, instead of being, as we sometimes congratulate ourselves upon being, in advance of others, we are somewhat behind them."

The Bill was submitted to the Labour Bills Committee for consideration over the recess.

The 'Lib-Lab' Government introduced a slightly modified Bill as soon as the new House met and this was enacted as the Factories Act 1891. In introducing the Bill to the Legislative Council on the 18th of August 1891 the Hon. Mr. Buckley said:
"... that this Bill is practically on the lines of a similar Act in operation in Victoria, and particularly on the lines of what is known as the English Act on the subject. It is very nearly the same thing, and it proposes to make our legislation nearly the same as that of England, in order that decisions given with respect to that Act may be taken advantage of in this colony."

The Act was amended in 1892 providing for the appointment of a Chief Inspector, and the Factories Act 1894 consolidated the two enactments and included further safety provisions for machinery and fire escapes.

2.3 The Development of Safety Health and Welfare Law: Although the I.C. \& A. Act was an entirely new concept, and a great step forward for labour law, and provided safety, health and welfare through the industrial awards, the commonly held view, that the foundations of safety legislation were laid in the early 1890s, can not be substantiated. Industrial safety law has developed as the specific accident problems have arisen and generally the comparable British statutes have been adopted. Apart from the Factories Act 1891 the 'Lib-Lab' Government was not able to pass any further labour laws in its first term of 
office because of the opposition of the conservative majority in the Legislative Council. It was not until after 1893 when it was returned to power with an increased majority and with Seddon at the helm that it was finally able to 'tame' the Upper House.

Even by 1896 unsatisfactory labour conditions had not been. eliminated and Seddon, who had taken over the labour portfolio from Reeves, in moving an amendment to the Factories Act on the 25th of September 1896 said:

\begin{abstract}
"In section 2 of this Bill honourable members would find that there had been the sweating evil existing, by which persons employed in factories, though they were by the Factories Act and regulations bound to work certain hours, had taken home work and sublet the same."
\end{abstract}

The Factories Act 1901 consolidated the 1894 and 1896 Acts and made minor modifications to the requirements for sanitation, hours of work, accident reporting, inspection and administration. Amendments were made to the 1901 Act in 1902 relating to working hours, in 1905 providing for rates of pay, e.g. persons over 20 with 4 years service were to receive not less than 17/- per week, and in 1906 regulating carbon monoxide gas. Other industrial safety, health and welfare measures enacted in New Zealand in the 19th century included the Coal Mines Acts 1886 and 1891, and the Mining Acts 1886 and 1891 , each requiring safe access and egress and safe ropes, chains, ladders and machinery, and providing for the safe use of explosives. These provisions were reproduced from the earlier British Mining Acts.

The Shops and Shop-Assistants Act 1894 limited the hours of work for women and young persons in shops to 52 hours per week. There were minor amendments to this Act in 1895, 1896 and 1901 also relating to hours of work. The shops and Offices Act 1904 was a consolidating measure but also added specific rules for sanitation in shops and offices.

Amendments to these Acts have been made from time to time this century and the Factories Act was consolidated in 1921, 1922, 1937 and 1946. The present Factories Act 1946 was based on the now out of date earlier British statutes. A consolidated 
New Zealand Occupational Safety, Health and Welfare Act has been recommended (see Chapter 4.8). The Tasmanian Industrial Safety, Health and Welfare Act 1977 and the Ontario Occupational Health and Safety Act 1978 together with the new Acts of Alberta, Saskatchewan, Manitoba, New Brunswick and Britain should be used as models for drafting the proposed New Zealand enactment (see Part III - Overseas Law). 


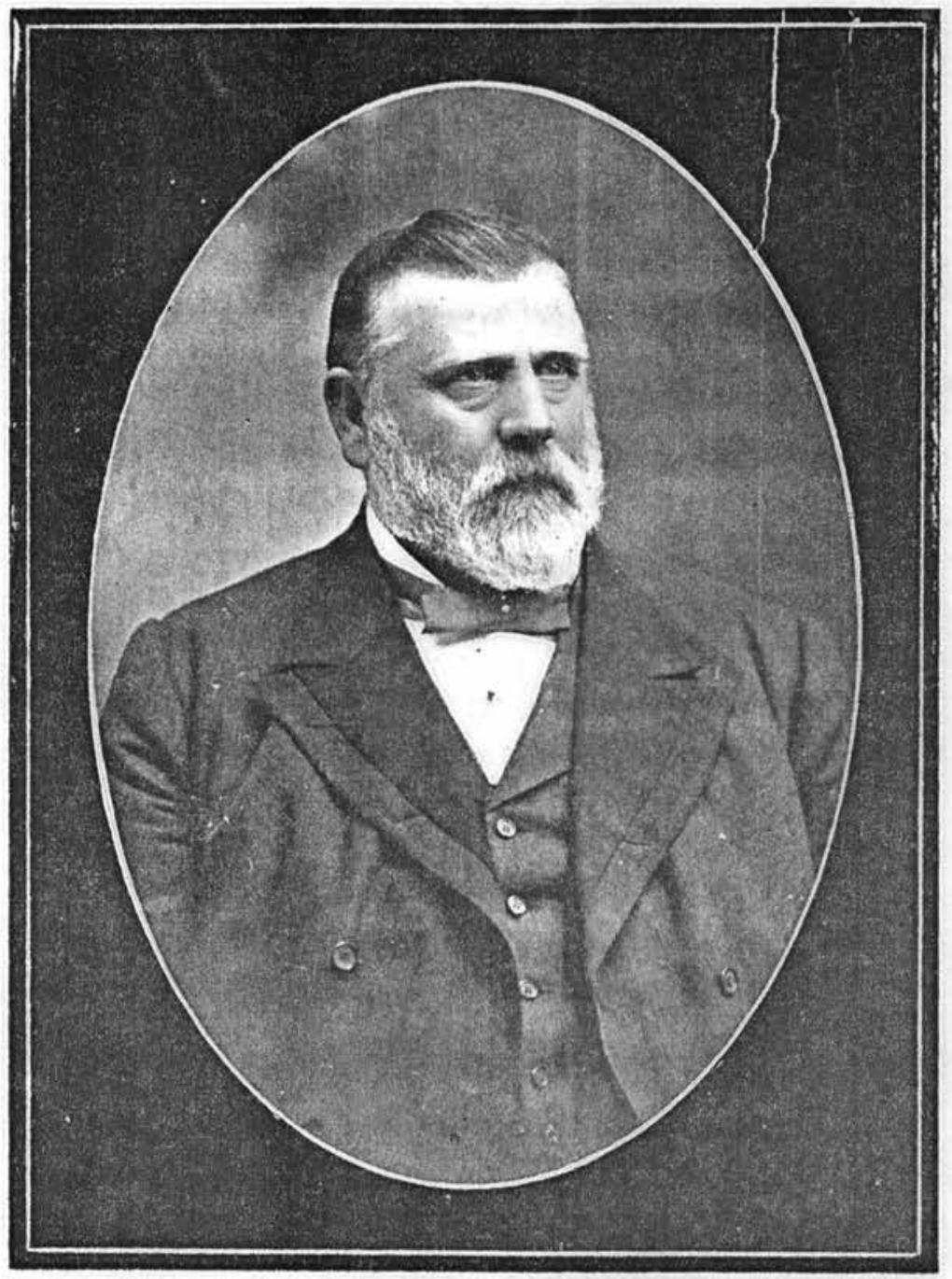

THE LATE RIGIHT HON, R, 1, SEDDON PREMIER AND MINISTER OF LABOUR. 1896 to 1906. 


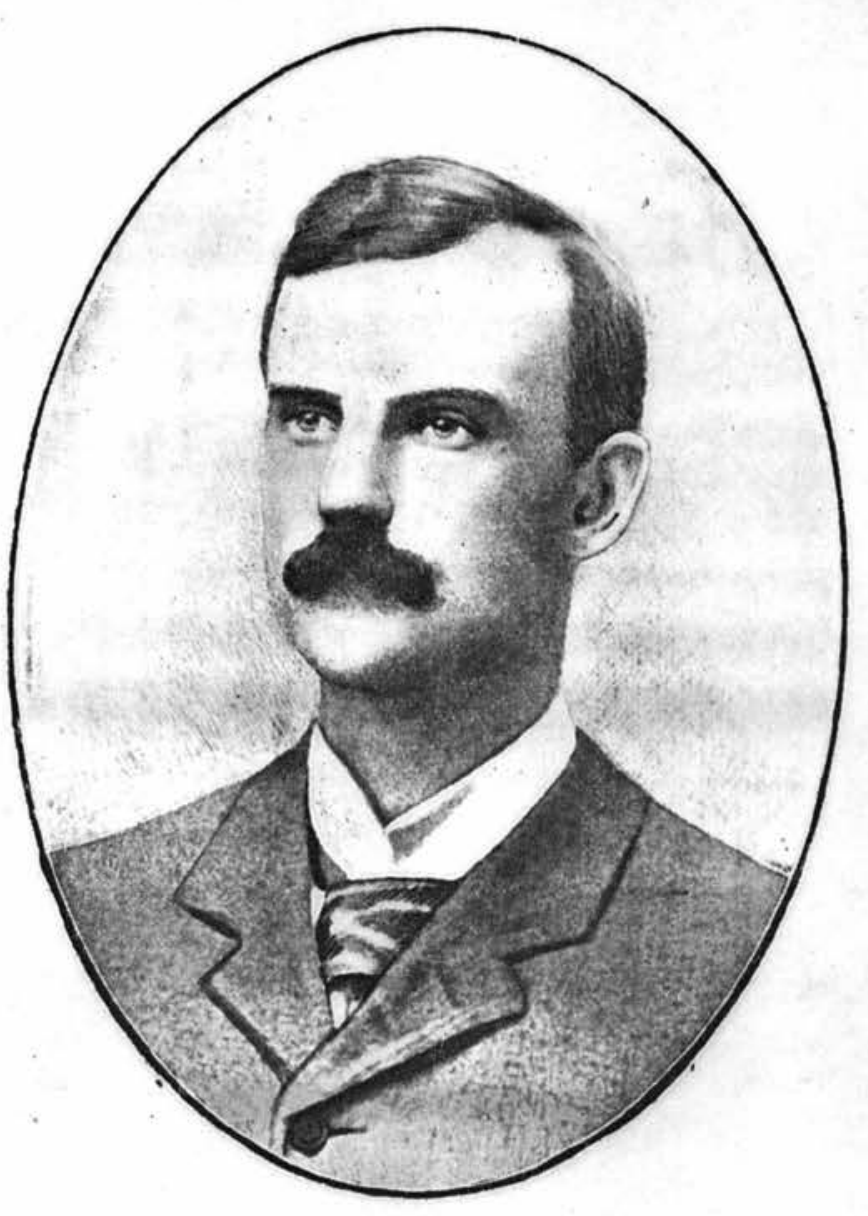

HON. W. P. REEVES,

Hä comMisstoskR yOR NEW ZEALAND

First Minixter of Labmur, 1891-96. 


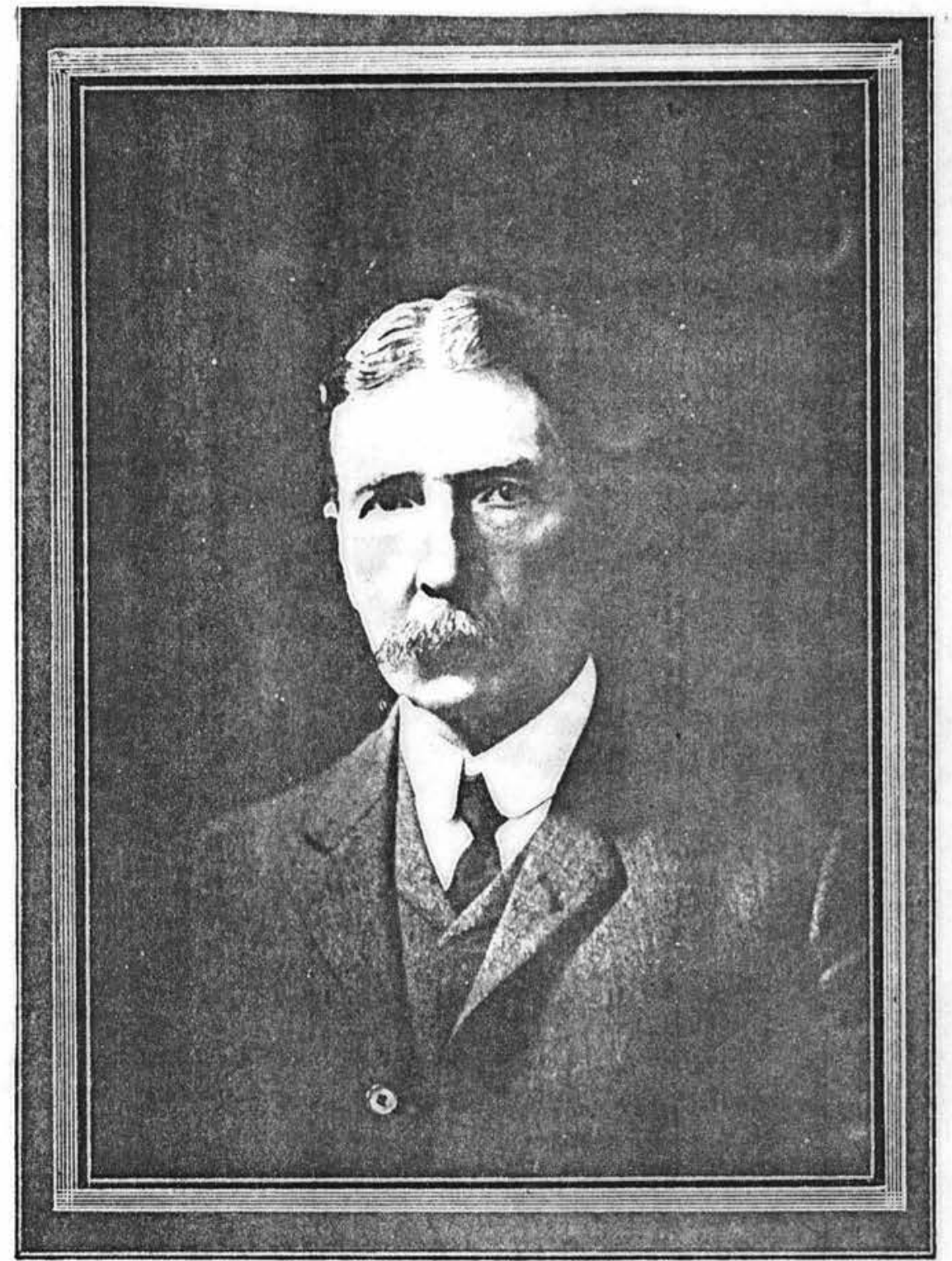

MIR. EDWAID TIEGVAR,

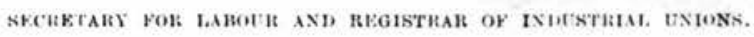




\section{Development of New Zealand Construction Safety Law}

When industrial safety, health and welfare laws have been required in this country British statutes have usually been adopted. Construction safety is the exception. British Factories Acts and the 'notional factory' have not been acceptable regulatory concepts for the New Lealand construction industry. From the start a separate legal and administrative framework has been developed. Accidents in building and civil engineering have always been high compared to other industries and the 19th century was no different. During its first term of office the 'Lib-Lab' Government in an attempt to reduce the number of fatalities and injuries endeavoured to pass a comprehensive and well drafted Bill covering the safety of persons engaged in construction.

\subsection{The 1892 Bill: The Bill intituled "An Act to provide} for the Inspection of Scaffolding and other Gear Used for the Construction of Works of any Kind" and with the short title of "Inspection of Building Appliances" was read a first time in. the House of Representatives on Friday the 24 th of June 1892. (See Appendix ' $B$ ').

The Hon. Mr. Richard John Seddon, in moving the second reading on the 17 th of August 1892, said:
"... that it (the Bill) provided for what had hitherto been an omission in making due and proper provision. for the safety of the lives of those who practically engaged in building and other trades in which the use of scaffolding was an absolute necessity. They had their inspection of machinery; they had their inspection of factories; and due precaution had been taken by the state in seeing that steps were adopted in all the cases he had alluded to to insure that the lives of those engaged therein were not endangered; but so far as buildings were concerned, they had very frequently, in different parts of the colony, accidents occurring, and serious loss of life."

He then listed a number of fatal and serious injury accidents that had occurred and emphasised the danger to the public as well as to the workmen.

The conservative opposition of the day said the Bill was "meddlesome interference", "unnecessary", "grandmotherly legislation" and that it "... would require half the population to be employed as inspectors". The Bill was discharged in the House on the 27th of September 1892, reintroduced in 1893 and 
again discharged on the 6th of September 1893. The Bill failed due to the legislative impasse caused by the conservative majority in the Upper House and the vigorous criticism expounded in the House of Representatives.

No further attempt at introducing legislation was made until 1906 although Public Works Department and local body engineers and Labour Department inspectors did carry out some inspections and accident investigations of construction work over these earlier years under provisions in industrial awards within the I.C. \& A. Act 1894 .

3.2 The Scaffolding Inspection Act 1906: This Act is set out as Appendix ' $C$ ' and it will be seen that "gear" and "scaffolding" are broadly defined to include all construction work over 16 feet in height and all items of plant and equipment. It provided for the appointment of inspectors, the notification of all "scaffolding", the making of regulations, the issuing by the inspectors of directions, cease work orders, appeals against the directions to the Minister of Labour, and for a penalty of £20. The Hon. Mr. Millar, the Minister of Labour in the 'LibLab' Government that held office until 1912, in moving the second reading said that:
"Buildings in the colony were getting higher and higher every year and there was no system of inspection anywhere. Local bodies had made spasmodic efforts but nothing general had been done. The Bill had been. submitted to the workers concerned and also to the Employers' Federation."

Mr. Edward Tregear, the first Secretary of Labour, in reviewing the first few months of operation of the Act stated in his 1907 Annual Report that:

\footnotetext{
"Under the Scaffolding Inspection Act, Inspectors have been appointed in the four chief cities, and have been diligently carrying out their duties. The appointments will be of great service in guarding life and limb from injury in building operations and the Act is one which meets with much approval from the workers."
}

Regulations for the erection of scaffolds for bricklayers, plasterers and painters, and for ladders, swinging stages and the covering of joists were made under the Act on the 17 th of 
December 1906 (N.Z. Gaz. 1906 p.3222).

The Act was amended in 1907 to give inspectors control over all scaffolding, to provide for ladders to extend 5 feet beyond the highest level to which it afforded access, for lifts to have automatic catches fitted and for the reporting of accidents. In the same year an additional regulation was made allowing inspectors discretionary power to approve alternative types of scaffolding (Gaz. 1907 p.674).

The Scaffolding Inspection Act 1908 was a pure consolidation of the 1906 and 1907 Acts. The 1908 Regulations (Gaz. 1908 pp.846 \& 1525) prescribed requirements for tripod gantries, hand-cranes, derricks, guard-rails on working platforms 10 feet in height and around well-holes and floor openings, scaffolds for carpenters, notification of work accidents and direction orders for inspectors. The Secretary of Labour's 1908 Annual Report highlighted accidents from contact with power lines, the use of cast-iron bolts in scaffold brackets, the use of rope guard-rails and unsafe ladders. In his 1909 Report the secretary recommended that the legislation should make clear who was responsible for maintaining scaffolding when several subcontractors were working on a large building. As will be seen from Chapter 5 this problem still exists today!!

Mr. R. A. Bolland the inspector appointed for Wellington reported a classic work situation in 1912:

"... a plumber was discovered working from a portion of an old pair of steps, nearly 30 feet above the ground, the steps stood on the top of a light box which was supported by a small nail barrel and this "structure" was placed upon a plank about 9 inches wide. A boy stood on the plank holding the barrel, the box and the steps in position."!!

The 1918 Regulations (Gaz. 1918 p.1078) consolidated and repealed the 1906, 1907 and 1908 Regulations and made minor amendments to the requirements for ladders, ladder brackets and guard-rails.

\subsection{The Scaffolding and Excavation Act 1922: Construction} safety legislation in New Zealand has developed as the need has become apparent and usually as the result of major accidents involving fatalities. 
On the 1st of February 1922, at Endean's Buildings Auckland, a beam on which scaffolding had been erected gave way and four painters fell some 75 feet to their death. The beam had been placed on its "flat" instead of on edge and thus failed due to overloading.

In a subsequent claim for compensation arising out of the accident a special jury added a rider to the verdict drawing attention to the Labour Department's neglect in enforcing the provisions of the Scaffolding Inspection Act 1908. However the Department had already called a conference of Inspectors and representatives of the employers and unions. This led in the same year to the passing of the scaffolding and Excavation Act 1922.

This new measure covered all operations in connection with the erection, demolition, or alteration of buildings as well as excavations for foundations, sewerage, gas, water and electric supply. It did not, however, apply to excavations made directly by any local authority or public body.

The requirement under the 1908 Act that notice of intention. to erect scaffolding over 16 feet in height was to be given to the inspector was altered to provide that notice was to be forwarded before any person began to do any building work where there was a risk of any person falling 12 feet or more, or before the erection of a crane, or before making an excavation more than 5 feet in depth. The person supervising the erection of scaffolding exceeding 25 feet in height, or a crane, was required to be certified by the inspector as to his competence. Each inspector was empowered to order safeguards for the protection of the workmen and the public, and to condemn and brand any gear that he considered unfit to use. Workers as well as employers were made liable for breaches for the first time and the onus was placed on the defendant to bring himself under exemption, proviso, excuse or qualification. For example if an inspector laid an information that the stiles of a timber ladder were less than the equivalent of 3 inch by 2 inch timber as required by the regulations the defendant would be required to prove that the actual ladder contained this equivalent timber. This provision has been carried forward into the Construction. Act 1959 as section 27. 
Regulations made in 1923 (Gaz. 1923 p.2743) under the new Act consolidated and revoked the 1918 Regulations. Additional requirements were prescribed for cranes and derricks, scaffolds, ladders, gantries and excavations. A Board of Examiners and a syllabus for the examination of inspectors were also provided.

In 1924, the Act was amended to cover all tramway works intended for the carriage of passengers and to require notice to be given before any person commenced building work if at any time a person might incur the risk of a fall of 12 feet or more. It had been held by the Court that under the principal Act notice was not required until there actually existed a risk of falling 12 feet or more. Similarly, the Act was amended to require notice of the commencement of any excavation work of any depth if the excavation was within a distance of 5 feet from any building that was more than 12 feet in height. Instances had occurred where excavations less than 5 feet in depth had been made close to adjoining buildings causing the buildings to collapse.

The 1923 regulations were revoked in 1935 and replaced with an updated set (Gas. 1935 p.3337) following consultation with the employers' and workers' organisations concerned. In particular, further safeguards for steel framed buildings and excavations were provided.

The Act was amended in 1948 to include excavations made by local authorities and by public bodies. The definition of "building-work" was extended to include "cleaning", that of "scaffolding" to include "suspended scaffolding" and "boatswains' chairs", and that of "excavation" to include "shafts and wells". The Act was extended to bind the Crown, but the effect of this provision is limited (see Chapter 5.4). An amendment made by the Statutes Amendment Act 1949 allowed for registered engineers employed by the Crown or by local authorities to be inspectors for work under their direct control.

In 1951 the Act was again amended and "construction work" was defined for the first time as:

\footnotetext{
"... any work in connection with the construction, repair, or maintenance of roads, streets, footpaths, access lanes, right of ways, motorways, railways, cableways, tramways, aerodromes, harbours, wharves, electricity or telephone or telegraph reticulation, reservoirs, pipelines, aqueducts, tunnels and reclamations."
} 
Thus the Act now covered all building and civil engineering work. The 1951 amendment also provided for the making of regulations for the safety, health and welfare of persons employed under the Act. The Hon. Mr. Sullivan, the Minister of Labour for the National Government, in moving the second reading said:
"This provision has been asked for by labour organisations. Honourable gentlemen will know that it does happen. that building and construction work is carried on without facilities that are essential in the interests of the men being provided. In such cases the Department will have the power by regulation to see that the sanitary and housing conditions and other necessary conditions are provided for the men."

These welfare requirements have been carried forward into the Construction Act 1959, and the inspectors are required to exercise discretion where the work is of a minor nature such as short duration maintenance, repair or alterations.

\subsection{The 1957 D.I.C. Scaffolding Collapse: At 2.30 p.m. on} Wednesday the 8th of May 1957 a steel scaffold 84 feet high crashed onto the pavement of one of the busiest shopping streets in Wellington in front of the large D.I.C. departmental store. Two pedestrians were killed, some nine people injured and it was miraculous that the casualties were not greater. As the tangled mass descended many people were quick enough to escape by running from beneath the falling verandah. Some of the workmen on the scaffold 'rode it down' and were not seriously injured while others ran along the upper scaffold planks and escaped to the remaining portions of the scaffold. The scaffold had been supported by the roof of the D.I.C. verandah 11 feet above the footpath and had been erected in progressive stages around the building for the purpose of carrying out light repair and painting maintenance to the exterior stone and plaster work. A visual inspection of the scene after the tangled steel tubing had been removed revealed that 45 feet of the verandah had collapsed onto the pavement, and that two steel joists in the verandah roof had broken loose at their outer ends from the heavy inclined steel hanger rods. 
The tragedy gained 'front page' publicity and a Royal Commission of Inquiry was immediately set up by the Government under the chairmanship of the late Sir Arthur Tyndall, and with two other prominent civil engineers as members, to inquire into and report upon the following matters:-

"(a) The cause of the accident;

(b) The type and structure of the scaffolding used, and its stability for the class of work for which it was erected, having particular regard to the safety of the workers and the public, and whether it complied with all existing statutes and regulations relating thereto;

(c) The competence of the persons responsible for the erection and dismantling of the scaffolding;

(d) The efficiency and adequacy of the inspection of the scaffolding by the person or persons responsible for that inspection;

(e) The administration of the Scaffolding and Excavation Act 1922 and of the regulations made under the Act;

(f) Suggestions for the prevention as far as possible of similar accidents in the future, and generally to inquire into and report upon such other matters arising and in particular to report your opinion whether any additional legislation is necessary and whether the regulations included in the existing law provide for reasonable and proper safeguards against similar accidents, or whether any amendments or additions to them are required."

The Commission sat on 39 days from June to August 1957 , heard 55 witnesses and considered 159 exhibits. It reported on the 25th of September 1957 and found that the cause of the collapse was the overloading of 2 bays of the scaffold with dismantled tubes and held that the legislation, particularly that covering steel scaffolding, was inadequate and confused.

The Commission recommended that the Scaffoldire and Excavation Act 1922 and the Scaffolding Regulations 1935 be completely overhauled and a new statute enacted, that dismantling of scaffolding be covered by the new Act, that scaffolders be certificated by examination, that confusion and overlapping with the Boilers, Lifts and Cranes Act 1950 and the Quarries Act 1944 be eliminated, that detailed regulations be made covering metal scaffolding, and that the 
inspection of scaffolding and excavation function be upgraded into proper focus with the other multifarious responsibilities of the Department of Labour:

3.5 The Construction Act Advisory Committee: Following the report of the Royal Commission the Minister of Labour set up a committee consisting of 3 representatives of the Employers' Federation and 3 from the Federation of Labour and with a civil engineer seconded from the Ministry of Works as chairman (Mr. E. E. Hendriksen, later to be appointed the first Chief Safety Engineer under the Construction Act 1959).

This committee considered in detail the recommendations of the Royal Commission and proceeded first to prepare a new Bill which ultimately became the Construction Act 1959 and then produced a draft of the regulations which became the Construction Regulations 1961.

The Construction Act Advisory Committee still exists and has two of its original members. It now meets at least once a year to consider amendments and additions to the legislation and to advise on supporting publications such as the Codes of Practice (see Chapter 4.5) and Guides issued under the Act. The role of the Committee has changed over its 22 years existence from a 'working group' to a 'sounding board' and its advisory nature has been accentuated in recent years. Additional representatives have been appointed from time to time, e.g. the Contractors Federation, the Master Builders Federation, the Building Research Association, the Accident Compensation Commission, the Fire Service Commission, the Municipal Corporations, the Counties Association, the Ministry of Works and Development and the Ministry of Energy. The Committee is now considered to be sufficiently representative of the industry so that if the Minister, or the Department, or one of the parties, wishes to obtain the industry's views the members are consulted either by telephone or by calling a meeting. Sub-committees have been set up from time to time to consider various specialist technical matters and to report back to the main Committee.

3.6 The Construction Act 1259: The Bill, as recommended by the Construction Act Advisory Committee, was introduced into the House of Representatives towards the end of the 1958 
parliamentary session, and interested parties were given an opportunity to examine it over the recess. Substantially the same Bill was reintroduced in 1959 by the Labour Government, which had just taken over office, and was referred to the Labour Bills Committee for consideration and further submissions from the various representatives of the construction industry.

A slightly altered Bill was returned to the House and in moving its third reading on the 17th of September 1959 the Hon. F. Hackett the Minister of Labour said:

\footnotetext{
"The objective of the Bill is to bring about greater safety in the building and construction industry. Recent figures show that over the past few years there has been no diminution in the accident rate. During 1957, the latest year for which statistics are available, ?,22? were injured in the industry at a cost of $\$ 449,078$ in compensation alone, not to mention the cost of the man hours lost. Twelve persons were killed, three were totally and permanently disabled and 147 suffered permanent partial disability. The sole aim of this Bill is to reduce the number of such accidents."
}

The main features of the new law were that the Act was to be administered by a qualified professional engineer, that the more hazardous works were to be notified to the Department and that the employer would be primarily responsible for compliance and would be required to appoint a safety supervisor on 'notifiable work'.

The only question debated in the House was the unique provision of nominating an engineer rather than the Minister or the Permanent Head as the administrator of the Act. Over the 20 years of operation of the Act there have been only two engineers appointed and in practice both have been prepared to accept departmental practices and procedures for the administration of the Act but both have jealously guarded the right to determine technical questions.

The Act together with the Regulations and the various publications provide a reasonably comprehensive code for safe working practices for all facets of building, civil engineering and associated trades, and over 100,000 workmen are covered by the provisions. The legislation is under review on a continuing basis and the Act has been amended each year 
since 1966 and the Regulations have been added to and amended each year since 1965 except for 1966, 1968, 1976 and 1978. (See Appendix A for a reproduction of the Construction Act 1959 and the Amendments.) 


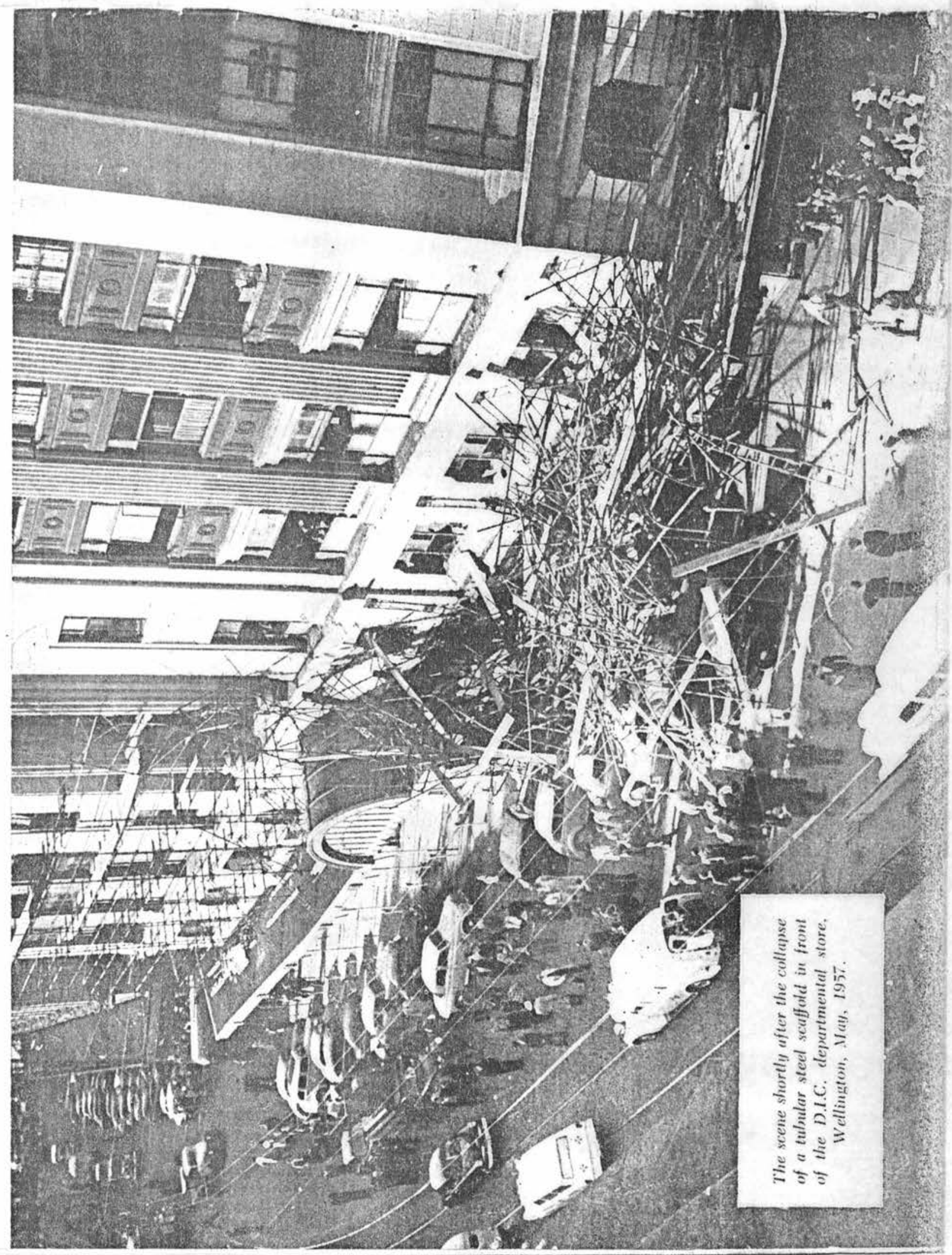




\section{PART II}

\section{ADMINISTRATION AND LAW}

\section{Implementation and Policy}

The purpose, effect, extent and application of the Construction Act 1959, its implementation, and such empirical subjects as sanctions, policy and practice, codes of practice, education, other legislation and reform are examined in this chapter.

4.1 Purpose and Extent: As can be seen f rom Part I, New Zealand construction safety law has developed as the practical needs have arisen, and new statutes have been passed after serious accidents have occurred. The 1906 Act resulted from a growing number of fatalities and serious injury accidents, and the 1922 and 1959 Acts are directly attributable to the Endean and D.I.C. scaffolding collapses. The various amendment Acts and regulations have developed as the specific needs have arisen.

The purpose of the Construction Act 1959 is the obvious one of reducing accidents and providing reasonably safe working conditions for those engaged on construction work. But of course accidents are not reduced just by passing law and are not entirely eliminated even if the provisions are complied with to the full. Each workman is limited by his own and his fellow workmen's awareness and actions, and his lack of understanding of even the elementary law of nature, statics and dynamics in the modern technological complex. Legislation can only reduce the foreseeable accidents and at its best safety law is only a code, compliance of which will provide safe means of carrying out conventional work operations. The written law tends to be at least one step behind changing technology because safety law develops as accidents occur and the need and a solution becomes apparent. Another factor is the time consuming nature of the consultative and law drafting process. It has been found, however, that even the starting of the discussions about a safety problem has an immediate and surprisingly quick reaction throughout industry, and contractors usually adopt the correct procedures before the law appears in its final written form. 
The Construction Act 1959 is designed:

"to make better provision for the safety and welfare of persons engaged in construction work".

However, s.3(2) extends its scope to cover the safety of all persons, including the general public, who are lawfully within the vicinity of the work.

The Act has a wide coverage and the definition in s.2 indicates the extent of the activities and undertakings included:

"Construction work" means any work in connection with the construction, erection, installation, carrying out, repair, maintenance, cleaning, painting, renewal, removal, alteration, dismantling, or demolition of -

(a) Any building, erection, edifice, structure, wall, fence, or chimney, whether constructed

wholly or partly above or below ground level:

(b) Any road, motorway, harbour works, railway, cableway, tramway, canal, or aerodrome: work:

(c) Any drainage, irrigation, or river control

(d) Any electricity, water, gas, telephone, or telegraph reticulation:

(e) Any bridge, viaduct, dam, reservoir, earthworks, pipeline, aqueduct, culvert, drive, shaft, tunnel, or reclamation:

(f) Any scaffolding;

and includes any work in connection with any excavation, site preparation, or preparatory work, carried out for the purpose of any construction work;

and also includes the use of any plant, tools, gear or materials for the purpose of any construction work;

and also includes any such work carried out underwater, including work on ships, wrecks, buoys, rafts, and obstructions to navigation; and also includes any inspection or other work carried out for the purpose of ascertaining whether construction work should be carried out."

\section{Exceptions:}

1. The Act applies only to "construction work" carried out by an "employer" by way of his trade or business .. s.3(4).

2. The Act does not apply to underground coal mining .. s.3(5) or any work in a quarry unless that quarry is declared to be "construction work" .. s.3(6). All quarries on the Waitaki Power Projects, the Homer Tunnel and some other projects which were technically "quarries" have been declared "construction work". 
3. The Act does not apply to "construction work" carried out by members of the New Zealand armed forces in the course of their duties...s.32. This exemption has been accepted for defence exercises but some contractors have objected to the relaxation of legal standards when the armed forces are engaged on public works such as the construction and demolition of bridges.

\subsection{Implementation}

Construction Safety Engineers:

The Act is administered by the Chief Construction Safety Engineer, under the general direction of the Secretary of Labour, and this engineer must be:

"a fit person with suitable engineering experience and qualifications comparable with the standard required for registration under the Engineers Registration Act 1924." (s.4)

Two persons have held this position, the first incumbent from 1960 to 1968, and the author of this thesis since 1968, and both had previously been senior engineers with the Ministry of Works.

The Construction Amendment Act 1978 provides for the appointment of Construction Safety Engineers, and the Amendment of 1973 for the delegation of powers by the Chief Construction Safety Engineer. At present there are two engineers appointed as Construction Safety Engineers, one qualified in civil engineering, and the other in mechanical engineering.

Construction Safety Inspectors: Appointments are made under s.5 and their principal functions as set out in $\mathbf{s . 6}$ are to promote and advise on safety, to ensure that the Act is complied with, to investigate accidents and to prevent or limit accidents. It can be seen that the inspector's policing or enforcement role is only one of a number of functions.

4.3 Departmental Policy and Practice: One of the principal functions of States is to secure the safety of its subjects, which includes the workforce, and therefore it has been. traditional for industrial safety legislation to be administered within central government rather than by local authorities, public corporations or private organisations. Also by retaining control of safety law central government is able to bring about the necessary degree of action required 
when accidents involving life and limb do occur. Industrial safety is intertwined with industrial relations and many disputes are concerned with safety health and welfare matters. In some disputes safety is made an issue by one or more of the parties in order to create an emotive atmosphere and a degree of urgency.

The implementation of safety is costly and it is basically a non-revenue earning area of administration and, therefore, it is continually under the watchful eye of the 'pruners'. From time to time arguments have been put forward for charging fees to recover the costs of the safety inspectorate activities but, although it is accepted that factories should pay registration fees, contractors have been reluctant to agree to the concept of paying for safety on construction, particularly because substantial sums are spent to meet the statutory requirements. However, in a number of the Australian and Canadian States and Provinces fees are paid as a percentage of the contract price (see Part III). In New Zealand, applicants for certificates of competency are required to pay fees to cover the costs of the courses and examinations.

The construction safety inspectorate service is kept to a minimum acceptable level in terms of staff numbers and resources such as transport and general administration. As will have been seen from Part I the only times there have been any major reviews or upgrading have been after serious accidents involving loss of life. Between these major accidents, and particularly in times of recession, it has been difficult to substantiate and retain reasonable standards to enable an adequate service to be provided.

In the final analysis the question of how much safety to provide is like asking how much defence is required. It is difficult to establish an acceptable norm and it is a financial and practical impossibility to provide a complete inspectorial coverage. In any case, the Construction Act 1959 clearly places the primary responsibility for compliance on the employer, and the inspector's function is mainly to see that these responsibilities are accepted.

At present, there are 56 inspectors employed under the Construction Act 1959 but 4 of these are engaged on administrative and technical work in Head Office and 12 in Districts on 
supervisory and educational work. Therefore the maximum number actually on the job engaged on inspection work over the whole country is 40 .

4.3.1 The Head Office Construction Safety Division: The Chief Construction Safety Engineer, the two Construction Safety Engineers, the four Construction Safety Inspectors and two administrative staff comprise the Head office staff. As well as carrying out the statutory functions under the Construction Act 1959, the Chief Construction Safety Engineer is the administrative head and controlling officer of the Construction Safety Division within the Departmental organisation. The Construction Safety Engineers concentrate on technical matters as they arise, and provide a professional engineering consulting service to industry. At present, work is proceeding on the preparation of codes of practice for falsework, asbestos, mechanical plant, rigging, bridge and road works.

The Chief Construction Safety Inspector has the responsibilities of co-ordinating and controlling the day to day functioning of the district inspectors including the continual updating of the Construction Safety Manual which sets out in detail the duties and functions of inspectors. The Chief Inspector is also the controlling officer for the other 3 Head Office inspectors who have the specific duties of inspector training, industry training (including the running of the certificate of competency scheme), accident investigation and reporting. Three of these Head Office inspectors have had extensive departmental and industrial experience, and they have specialist practical skills in subjects such as explosives, mechanical plant, underwater diving, major engineering construction and multi-storey building work. A senior and a junior administrative assistant provide the backup assistance to the head office team including the secretarial services for the Construction Act Advisory Committee and its various sub-committees.

4.3.2 The District Inspectorate: In the larger districts, i.e. Auckland, Manukau, Hamilton, Wellington, Christchurch and Dunedin a supervising inspector is appointed to control and organise the work of the other inspectors engaged in those districts. There is also an assistant supervising inspector and 
a regional education inspector in the Auckland, Wellington and Christchurch offices. The district inspectors are primarily responsible for carrying out their statutory duties and functions as laid down in the Construction Act 1959 and as expanded in the Manual. Various priorities such as accident investigation and work coverage are set out for the benefit of inspectors. The district inspectors are under the control of the District Superintendents for day to day administration but report direct to Head office on technical matters.

\subsubsection{Enforcement Policy and Practice: A basic prosecution} policy is laid down thus minimising the need for discretion by the individual inspectors. This policy has two arms. Firstly, prosecutions proceed where accidents involving fatalities or serious injuries occur and the Act or regulations have been breached by a company or person other than the injured. It is not usual to prosecute a person who has been injured as a result of his own disregard of the legislation, unless others have also been injured, as the accident and injury itself usually provides sufficient punitive affect. Secondly, where an inspector's directions to comply with the provisions of the Act have been deliberately ignored, prosecution follows.

Before a prosecution is recommended the inspector is required to thoroughly investigate the matter and to set out in standard form the details of the breach and the circumstances surrounding the particular instance. The District Superintendent signs the form as recommended (or not) and must forward it to Head Office. The papers are examined and reported on by the Chief Inspector and one of the engineers in. Head Office and if necessary they consult with the office solicitor. A signed recommendation is then presented to the Chief Engineer who either approves or rejects the prosecution. If it is approved a decision is made as to whether to engage Crown counsel. Inspectors are given some basic training in and are encouraged to take prosecutions unless there are likely to be matters of law involved.

Inspectors have a range of administrative alternatives to enforcement through the courts and prosecutions are seen as the last resort, 'the end of the road'. Thus the proportion of the total number of violations detected by inspectors which are 
brought to court is very small indeed. In most instances the inspector has only to mention to the employer or his representative the requirements that are to be met and the matters are attended to immediately. It is indeed the rare exception to find a 'wilful' disregard of construction safety law.

It can be argued that to proceed to prosecution where a breach coincides with an accident but not to proceed where there is a breach but no accident is inconsistent and only compounds the employer's misfortune. However practical considerations have assisted in formulating this policy. Firstly, since the abolition of the civil claim upon the enactment of the Accident Compensation Act 1972 the Department has come under greater pressure from the unions, and family relations of the injured, to proceed with a proescution. There is now no other way that the matter can be aired in any court. Secondly, when an accident involving injury occurs the inspector is required to go to the site as soon as possible and to carry out a detailed investigation which highlights and documents any breaches. Thus all the necessary information for a prosecution has been obtained. Thirdy, it is seen by both employers and workmen that although every endeavour is made to avoid accidents and to comply with the law, when a person is killed or seriously injured and the accident is associated with a breach, then those responsible should expect the severest consequences. Fourthly, this prosecution policy has been operating for ten years and no complaint or criticism has been forthcoming except that Government Departments undertaking construction work are not subject to prosecution (see chapter 5.4 ).

Inspectors do not regard themselves as members of an industrial police force primarily concerned with the detection, apprehension and subsequent punishment of offenders. Rather they perceive their major function to be that of securing compliance with the standards of safety, health and welfare by co-operation and thereby achieving the ends at which the legislation is directed. They choose their methods of operation by functional efficiency which in normal circumstances amounts to regular inspection, check visits and 
occasional threats. Inspectors tend to view the prosecution of offenders as an intrusion on their normal inspecting functions. The additional time and paper work inevitably involved in court action renders it a method of obtaining compliance to be used sparingly and only in the last resort. Prosecution is seen by inspectors as a means to an end rather than an end in itself.

One determining factor in the mind of the inspector in considering a prosecution is the reception he receives when. asking for compliance, and the attitude of those responsible. If he has a satisfactory working relationship with the site personnel and he knows that remedial action will be taken immediately he will be reluctant to proceed to court action. Thus in time inspectors tend to build up informal procedural site rules associated principally with the general attitude of employers, or their representatives, and the promptness of their response to demands made. If these informal rules or norms are not breached sometimes serious offences escape severe action. whereas comparatively minor offences not corrected can provoke legal proceedings when these norms are broken. Inspectors are sometimes motivated into considering court action when a particular employer needs a sharp reminder of his responsibilities to shake him out of a complacent and non-cooperative attitude. Prosecutions do have a salutary effect on contractors because of the loss of prestige and status within the industry even although the financial penalty in most cases is infinitesimal in relation to the daily costs on a project.

4.4 Sanctions

4.4.1 Penalty: Section 24 , as amended, states that:

"Every person who commits an of fence against this Act or against any regulations for the time being in force under this Act for which no penalty is provided elsewhere than in this section is liable to a fine not exceeding $\$ 2,000$ and, if the offence is a continuing one, to a further fine not exceeding $\$ 20$ for every day on which the offence has continued:

Provided that where the offence does not directly involve the safety of workmen employed in construction. work, the fine shall not exceed $\$ 100$, and if the offence is a continuing one, the further fine shall not exceed $\$ 2$ for every day on which the offence has continued." 
Fines over recent years have ranged from $\$ 25$ to $\$ 1,500$ plus costs and they tend to average at about $\$ 150$ plus costs. About 40 prosecutions are taken each year mostly against employers and usually on more than one information. Convictions are entered in over $90 \%$ of the cases.

Offenders have never been charged with a continuing offence because most prosecutions result from individual inspection visits and evidence of continuity is difficult to obtain with the degree of exactitude required. Also conviction for an individual offence is considered to be sufficient punishment to ensure future compliance.

For major construction companies the penalties are insignificant but the publicity affect on these contractors acts as a very real deterrent.

4.4.2 Stop Work Orders: Section 18(3) states that:

"Where an Inspector gives any directions under subsection (1) of this section, he may also, at the same time or subsequently, order any persons to cease forthwith such work in connection with the construction work as may be specified in the order until the directions are complied with, and the employer shall advise all workmen likely to be affected by the order."

A cease-work order is the most powerful deterrent under the Construction Act 1959. Disruption to work operations because of a safety matter has an immediate and serious affect on the project programme and also on costs. Many thousands of dollars are frequently spent to comply with the safety requirements under the Act. The threat by an inspector of a cease-work order will usually bring faster reaction and results from contractors than the threat of a prosecution. However, seldom is it necessary to actually issue the order. For cases decided under section 18, see para.5.6.2.

4.4.3 Replacement of Safety Supervisor: Section 10(1) states that:

"Where in the opinion of an Inspector any person appointed under section 9 of this Act as a safety supervisor is unfit to hold the appointment by reason of incompetence, or gross negligence, or misconduct in the performance of his duties under this Act, the Inspector shall notify in writing the employer by whom the safety supervisor was appointed that the safety supervisor shall no longer hold office as such for the construction. 
work in respect of which he was appointed and that a new safety supervisor be appointed in his stead."

This provision has only been invoked 5 or 6 times over the 20 year period of the Act. However, here again the threat of replacement is usually a sufficient deterrent to ensure compliance. Also this sanction is linked with the fourth sanction, the suspension or revocation of a certificate of competency. Regulation 97(7) requires that a safety supervisor must hold a certificate of competency and therefore suspension or revocation has the same effect as replacement of a safety supervisor under section 10 of the Act.

4.4.4 Suspension or Revocation of a Certificate of Competency: Regulation 14 of the Construction Regulations 1961 provides that:

"(1) The Chief Safety Engineer may revoke any certificate of competency if:

(a) It is proved to his satisfaction that the holder has died:

(b) The holder has been guilty of such improper conduct in the execution of his duties as renders him, in the opinion of the Chief Safety Engineer, unfit to be the holder of the certificate:

(c) The holder has been culpably negligent in the execution of his duties to such an extent as to endanger the life of any person.

(2) Instead of revoking any certificate of competency as aforesaid, the Chief Safety Engineer may, on any ground specified in paragraph (b) or paragraph (c) of subclause (1) of this regulation, suspend the certificate for such period as he thinks fit."

Twenty certificates of competency have been either suspended or revoked under subclause (b) or (c) over the last ten years.

Regulation 15 provides for a Board of Appeal consisting of a Magistrate and two assessors one of whom shall be appointed by the Chief Safety Engineer and one by the appellant.

There has been one appeal under this provision that of A. H. Pilling V. Chief Safety Engineer (unreported 1.6.76). Pilling appealed against the suspension of his certificate of competency as a construction blaster. The Board of Appeal, (K. L. Richardson, S.M. was the Chairman) reduced the time of suspension and held that the standard of care to be applied under the Act is that of: 
"the ordinary, reasonable and prudent blaster, similar to that which the law requires of motor drivers in the handling of vehicles under their charge."

4.5 Codes of Practice: In the late 1960s a number of fatalities and accidents occurred to underwater divers engaged on construction work in harbours, foreshores, lakes and rivers and also to persons engaged in work in compressed air in connection with the construction of bridge piers and in particular on the Auckland Harbour Bridge Project. It was decided that regulations were necessary and a guide and draft regulations were prepared on each subject. However, after discussions with the law draftsman (now called parliamentary counsel) it was found that the engineering technology could not be presented adequately in the form of regulations and it was decided to make provision in the Act for Codes of Practice.

Therefore in 1970 sections 18A, B, and C were added to the Act, and section 30 amended, to provide a procedure for industry, ministerial approval and the declaration by the Chief Safety Engineer of Codes of Practice. The Underwater Diving and the Work in Compressed Air Guides were then. declared to be Codes of Practice. In 1971 regulations 118 and 119 were made requiring persons to comply with these Codes. In 1974 regulations $36 \mathrm{~A}$ and $70 \mathrm{~A}$ were made requiring compliance with the Codes of Practice for Scaffolding and Excavations.

Although the validity of these Codes has not been tested in the courts it is considered that the specific requirements laid down in them are binding in law. Mandatory Codes have the advantage over regulations in that they are presented in technical language readily understood by construction personnel and are accompanied by appropriate tables and explanatory diagrams. They have become 'law in the layman's language'.

The only problem associated with these Codes is that they need revising and reprinting every few years and it is necessary to remake the regulations and nominate the particular date of issue each time. However, it is important that this principle be retained otherwise the situation would arise where the Chief Safety Engineer would be making the law which Parliament has delegated only to the Governor-General in Council. It is interesting to note that the first British factory inspectors had regulation-making powers!! 
4.6 Safety Education: The Construction Act provides for safety promotion and the Department of Labour has been active in this field since its creation in the 1890s. The Accident Compensation Commission is also involved in safety education and the Department now limits its role to the statutory and technical subjects under the industrial legislation it administers. The Commission covers the wider field of safety promotion and attitudes to safety in the total community.

Under the Construction Act 1959 safety education and promotion is carried out, firstly, by the day to day inspections and, secondly, by a formal education scheme which is implemented primarily through the certificate of competency and registration. procedures.

4.6.1 Certificates of Competency: The Act requires that work on excavations s.12(e), scaffolding s.13(c), mechanical plant $\mathrm{s} .14(\mathrm{~d})$, the use of plant, tools and gear s.15(b), and explosives s.16, shall only be carried out with persons who have prescribed qualifications. The regulations set out in detail the requirements for persons to obtain certificates of competency for safety supervisors, scaffolders, construction. blasters and powder-powered tool operators.

On application and payment of the prescribed fee a candidate for a certificate is interviewed by an inspector and supplied with the necessary study material in the form of Codes of Practice and Guides and he is scheduled into a three day course and later a three hour written examination. For the purposes of certification the country is divided into three regions, one for the South Island, and the North Island is bisected. A regional education inspector is appointed for each region stationed at Auckland, Wellington and Christchurch, and they have the duties of organising the courses and examinations within their region including the lecturing, the marking of the papers and the forwarding of the results to Head office. They can call upon local inspectors to assist with the lecturing and the supervision of the examinations. The course Manuals and the examination papers are prepared and checked in Head office. Finally, the certificates are completed, signed individually by the Chief Safety Engineer and forwarded to Districts for distribution to the candidates. Consideration is being given 
to centralising the education units in Head Office and eliminating the regional scheme as it appears that some saving in cost can be made.

\subsubsection{Registration: A registration scheme is in operation} for underwater divers, riggers and mechanical plant operators. Under this scheme a sub-committee of the Construction Act Advisory Committee sets the criteria for registration, and a check is made to see that each candidate meets these requirements. If he does, his name is entered in the register and he is sent a certificate of registration.

The advantage of registration over certification is that the instruction is provided by other organisations besides the Department of Labour. One of the main objections to the certification scheme is that the Department of Labour is the only organisation providing the instruction in the particular specialised subjects and thus it becomes the recognised authority and the main repository of the particular technology. It is considered that formal education should be carried out by the technical institutes under the auspices of the Education Department thus leaving the inspectors more time for actual inspections. The principal argument for retention by the Department of Labour is that the certification scheme has been a success since its introduction in 1968. The safety supervisor scheme in particular has been a major operation. Over 15,000 supervisors have now completed their training and have been. issued with certificates of competency.

4.6.3 Management Safety Seminars: In addition to certification and registration the Department of Labour conducts one day Management Safety Seminars, in the various centres, throughout the country. These seminars have been reduced in number since the passing of the Accident Compensation Act 1972 as the Commission has a responsibility in this area and has more funds available. But when there is a specific safety problem to be explained to industry, such as a run of accidents on some particular facet of work, or new technology, or additional legislation, it has been found that the Management Safety Seminars are the ideal forum for the dissemination of information.

As well as these formal Departmental schemes the engineers and inspectors are regularly requested to present papers, give talks and prepare articles on construction safety subjects. 
4.7 Other Legislation: In New Zealand, industrial safety law has developed as the practical needs have arisen, with the result that there exists a proliferation of different statutes and regulations. (See Part I.) These unco-ordinated and in. many cases outdated pieces of law are administered by various inspectorates within a number of Government Departments and they contain areas of overlapping jurisdiction.

The New Zealand Construction Act 1959 includes two subsections that make it necessary for those engaged in construction to have a sound working knowledge of other Acts and Regulations:

Section 3(1): "The provisions of this Act are in addition to and not in substitution for the provisions of any other Act and nothing in this Act shall derogate from the provisions of any other enactment. Compliance with the provisions of this Act or any regulations under this Act shall not confer any relief or exemption from liability under any other enactment but no person shall be convicted of any offence under this Act in respect of the same matter for which he has been convicted of an offence under any other enactment."

Section $11(\mathrm{f})$ : "The provisions of any enactment making provision for the safety of persons and applicable in respect of workmen engaged in any construction work shall be complied with by the employer and workmen engaged in that construction work."

There are over 30 different Acts and Regulations that directly affect construction work.

4.7.1 Administered in the Department of Labour

(1) The Factories Act 1946: The definition of 'factory' in the Factories Act 1946 excludes, any building in the course of erection; and all construction work such as repair, maintenance, painting etc., carried out in an operating factory, comes under the Construction Act 1959. This applies even if such work is carried out by workmen on the payroll of the factory occupier. (2) The Factories Consolidating Regulations 1937: deal with fire-escapes, lighting of interior egress, doors and gateways, fire prevention appliances, sanitary accommodation, air space and registration.

(3) The Abrasive Blasting Regulations 1958: cover abrasive blasting, enclosures, protective clothing and amenities. 
(4) The Lead Process Regulations 1950: cover premises, equipment, cleaning, amenities, protective clothing, medical examination, register of workers, duties of persons working in lead processing works and labelling of lead paint containers.

(5) The Spray Coating Regulations 1962: deal with the construction of booths, ventilation, drying of sprayed articles, coating with toxic substances, medical examination and restrictions on employment, electrostatic spray coating, storage of inflammable substances and amenities.

(6) The Machinery Act 1950: covers the inspection and safety of persons using machinery and includes machines used on building and engineering construction.

(7) The Woodworking Machinery Regulations 1956: deal with the safeguarding and use of woodworking machines including circular saws, band saws, planers, shapers, morticers, routers, sanders and power hand tools.

(8) The Tractor Safety Frame Regulations 1967: deal with the testing of safety frames fitted to agricultural tractors. (9) The Bushworkers Act 1945: governs the safety of persons working in bush undertakings. 'Construction work' may include a bush undertaking e.g. clearance of land for roads, power projects, airports, transmission lines etc.

(10) The Explosives Act 1957 \& Regulations 1959: govern the classification, importation, manufacture, sale, storage, carriage, packing, marking, handling, abandonment and disposal of explosives.

(11) The Dangerous Goods Act 1957 \& Regulations 1958: deal with the classification, storage and use of dangerous goods.

4.7.2 Administered in the Ministry of Transport (Marine Division)

(1) The Boilers, Lifts and Cranes Act 1950: covers the inspection, certification and safety of boilers, lifts, cranes and certain types of machinery. Dual inspection and administration constantly occur because of the overlapping provisions of this Act and the Construction Act 1959. (2) The New Zealand Power Crane Rules: govern the design, construction, inspection, testing and maintenance of cranes. Section 14 of the Construction Act 1959 also deals with the safety of cranes. 
(3) The New Zealand Power Lift Rules: govern the design, construction, maintenance, inspection, testing and operation of lifts.

(4) The New Zealand Boiler Code: covers the design, construction, inspection, testing and maintenance of boilers. (5) The Fusion Welded Steel Pressure Vessels Rules: deal with the design and manufacture of fusion welded steel pressure vessels.

4.7.3 Administered in the Ministry of Energy (Mines Branch) (1) The Quarries Act 1944 \& Regulations 1959: govern the safety of workmen in quarries, and tunnels. There is some overlap in jurisdiction between this legislation and the Construction Act 1959. (See para.4.1).

(2) The Petroleum Act 1237 \& Regulations 1939: deal with the mining of petroleum and include safety provisions for pipelines, rigs etc.

4.7.4 Ministry of Energy (Electricity Branch)

(1) The Electrical Supply Regulations 1967: apply to the construction and maintenance of electric lines and works comprising transmission, reticulation, and services.

(2) The Electric Linesmen Act 1959 \& Regulations 1960: provide for the training, qualification and certification of electric linesmen, including safety requirements.

(3) The Electrical Wiring Regulations 1961: apply to all electrical installations.

(4) The Electricians_Act 1952 \& Regulations 1956: govern the registration of all electricians.

4.7.5 Administered in the Ministry of Works and Development The Geothermal Energy Act 1953 \& Regulations 1961: prescribe safety precautions for geothermal energy development.

4.7.6 Administered in the Health Department

(1) The Health Act 1256 \& various regulations: cover sanitation, drainage, waste etc.

(2) The Plumbers and Gasfitters Registration Act 1964 \& Regulations: deal with the qualification and registration of plumbers and gasfitters. 
4.8 Reform: The many various existing Acts and regulations are a patchwork of individual measures that over the years have been developed to meet immediate needs. They do not form a structural and coherent unit designed to express an overall policy. The ultimate aim of any comprehensive effort in the area of industrial safety, health and welfare legislation is to eliminate accidents and eradicate occupational disease. This law is concerned with people at work and one of the essential requirements is for it to be understood, and this is the main reason why consolidation is essential. As will be seen from Part III the trend overseas is towards the one occupational enactment, and with separate regulations and codes of practice covering each industry. Thus the same basic legislative framework setting out fundamental responsibilities, rights, duties and concepts is provided for all people at their place of work.

Legislation by itself, however, cannot create the conditions essential for a major improvement in accident rates. Neither can Government resources or machinery alone produce the required results. There must be co-operation and active participation of all the industrial groups concerned. The responsibility for the safety of individual employees does not lie with Government and there is no need to set up a bureaucratic superstructure. The aim of Government should be rather to encourage employers and working people to assume basic responsibilities themselves. This does not mean that Government should wash its hands of all control. Such an attitude would lead to a worse situation than the existing one. The proposed approach would make Government responsible in a more meaningful way and would involve two major operations. The first, and the most important, is the one already mentioned, i.e. creating conditions to enable working people and employers to assume the basic responsibilities. The second, is the setting up of a unified legislative framework that all persons can easily consult and understand.

4.8.1 Acceptance of responsibility by industry: If industry is to assume responsibility for occupational safety, health and welfare their rights and obligations must first be clearly 
established and stated. There is almost nothing in existing legislation concerning the rights of working persons, and it is fundamental in the modern industrial complex for those directly involved to be able to participate in the preventive process. For instance, to ensure that mechanisms of co-operation are established employees must have the legal right to demand the setting up of site safety committees. Joint industry and sector groups should also be established. If responsibility is to be fully assumed at the place of work adequate training, information and research facilities must be provided. Both employees and employers must be made aware of occupational hazards, and the means of eliminating or avoiding them, if they are to institute on the job preventive measures, and develop suitable attitudes and behaviour patterns.

4.8.2 The Legal framework: There is no doubt that safety, health and welfare legislation is required to achieve acceptable minimum standards in all industries. Both employers and employees in construction and in other industries have, for a long time, been demanding the consolidation and clarification. of the existing statutes. An analysis of the existing framework reveals that the New Zealand legislation is unco-ordinated and very complex. As a result it is difficult, and in some cases impossible, for the people, the laws are supposed to protect, to take advantage of them, and for inspectors to properly enforce their provisions. Besides determining the basic responsibilities and rules any new consolidating enactment must provide for transitional measures for changing over from the present legislative hodge-podge' to an integrated system. 4.8.3 Construction work: The construction industry by its nature has special problems which have been recognised in the past by the establishment of the separate Construction Act 1959 and its predecessors (see Part I). These specific needs must not be lost sight of in the consolidating process. It has been found for instance that the permanent joint committee mechanism that operates in other individual industries will not work in construction. Construction work is temporary and operates in a continually changing environment with a constant 
turnover of employees and jobs which last a relatively short time. The initial operations are usually carried out from temporary workshops and accommodation, and the work activities vary from day to day and sometimes from hour to hour. Physical conditions and situations alter as the project progresses, and new materials and special design techniques have to be used. Organisation, management and job control are affected by the numbers of different trades and sub-contractors that have to be phased in and catered for at the various stages of the construction process. 

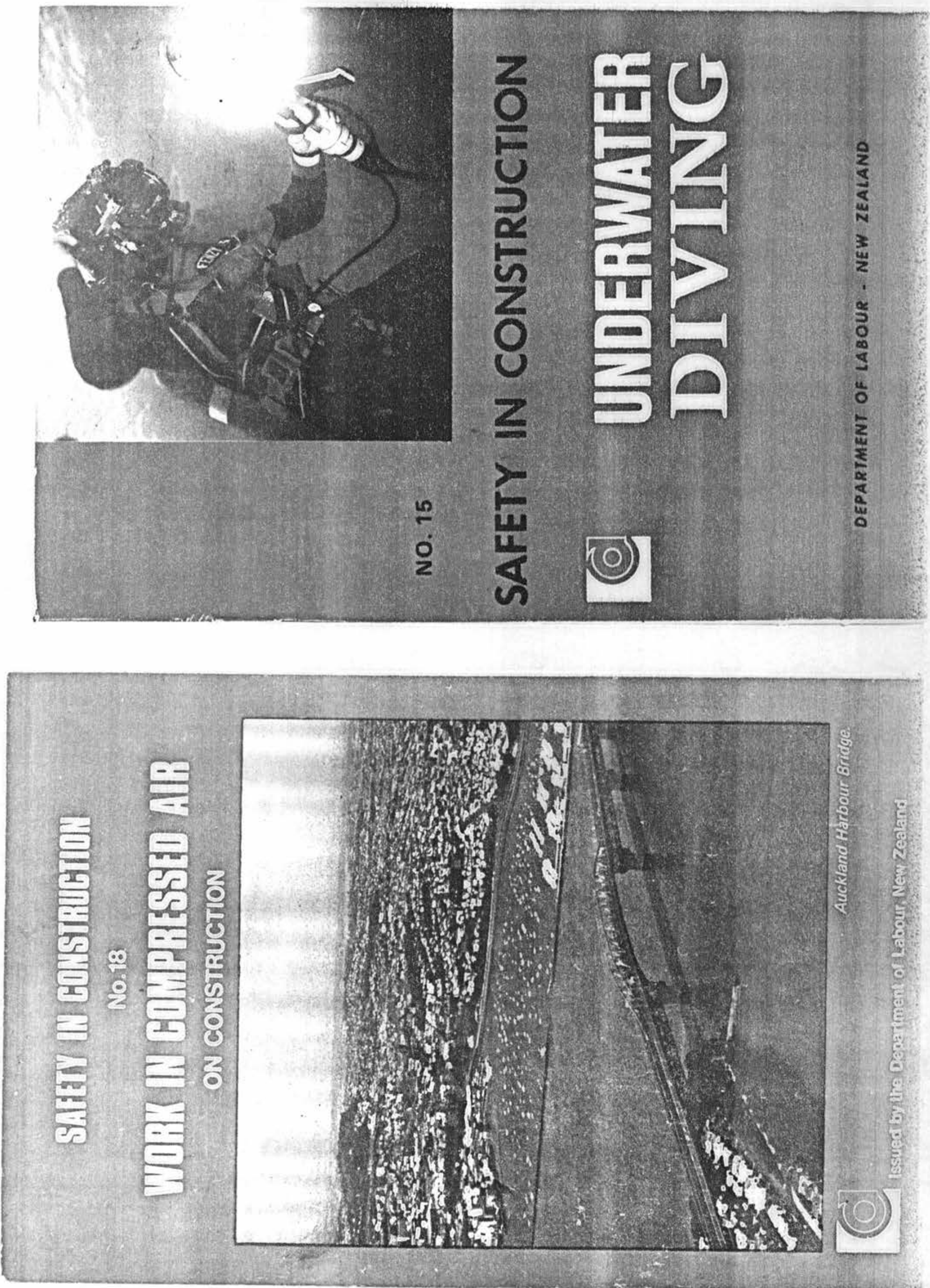


\title{
5. Liabilities
}

5.1 'Employer': Section 22 of the Construction Act 1959

sets out the liability of employers:

"In every case where under this Act any requirement, obligation, rule, or provision is imposed or enacted or required to be observed with respect to or in connection with any construction work the employer shall cause the requirement, obligation, rule, or provision to be duly and faithfully complied with or observed, and if the requirement, obligation, rule, or provision is not duly and faithfully complied with or observed the employer commits an offence against this Act."

\subsubsection{Who is an 'employer'?: Section 2 provides a} definition:

\begin{abstract}
"'Employer', in relation to any construction work, means any person. who is liable for the payment of wages of men employed on the work or who would be so liable if men were so employed; and, in respect of the operation of mechanical plant, includes a bailee of the plant, notwithstanding that the bailee is not liable for the payment of the wages of the plant's operator."
\end{abstract}

This definition was an issue in Safety Inspector v. Auckland Regional Authority (1978) 14 M.C.D. 163. The A.R.A., who had contracted work to a group of four workmen, on a work done basis of payment, was held by B. H. Blackwood, S.M., after considering written submissions from counsel, to be an 'employer' under the Construction Act 1959. The words 'wages', 'employed' and 'or who would be so liable if men were so employed' were also examined in this case, and the interpretation and comment are set out in paras. 5.1.2, 5.1.3, and 5.1.4.

5.1.2 'Wages': It was held in the A.R.A. case that the word 'wages' is to be construed in its wider sense, so as to include payment for services rendered, whether calculated on an hourly, weekly, annual, piece-work, production or yardage basis. Therefore, the method or basis of payment does not exclude a person from being an 'employer'.

5.1.3 'Employed': Whether a person is 'employed' depends whether his contract is one 'of service' or one 'for services'. Mr. Blackwood in the A.R.A. case considered the following authorities: 
Halsbury's Laws of England, 3rd Edition, Vol. 25, p.452, para.879; Ready Mixed Concrete v. Minister of Pensions [1966] 1 All E.R. 433, Stevenson, Jordan \& Harrison Ltd. v. Macdonald [1952] 1 T.L.R. 101 , Hargreaves V. Mayhead Bros. Ltd. [1971] N.Z.L.R. 559, and Ferguson v. Dawson [1976] 3 All E.R. 817, and he concluded that:

"The general principles of law which I find apply to the question of determining whether the contract in this case is a contract of service or a contract for services are briefly these:

1. There must be a contract in which the worker is paid for his work and skill, whether payment is calculated by reference to time worked or services performed.

2. There must be a degree of control by the master as to how the work is performed sufficient to establish that the person who let the contract is in fact the master.

3. The Court is bound to examine the contract as a whole to determine its true nature, and may and, indeed, should disregard terms of the contract contrary to the nature which the Court determines is the true legal relationship between the parties.

4. The relationship between the parties is determined by law and not by the label which the parties choose to put on it.

5. It is of assistance in determining that relationship to consider the principle of 'integration' enunciated by Denning L.J. in Stevenson's case."

Since the A.R.A. case the decision in Australian Mutual Provident Society v. Allan and Another (1978) 52 A.L.J.R. 407 has become available. The issue in that case was whether an A.M.P. representative's contract was one 'of service' or 'for services'. The Privy Council held that the representative was not an 'employee' but an 'agent' under a contract 'for services'. Determining factors were that he was entitled to enter into a partnership, to appoint sub-agents, to incorporate himself, that he was not obliged to do any work and that half of his income was deducted as business expenses in his tax return. None of these factors affect the principles formulated by $\mathrm{Mr}$ Blackwood. 
5.1.4 'or who would be so liable if men were so employed ':

Mr. Blackwood in the A.R.A. case stated that:

"At first sight these words seem to defy interpretation. I apprehend, however, that they are intended to cover voluntary workers, such as those attending working bees with a Parent Teachers Association. The legislature may even have intended to cover the type of situation we have in this case. Men are working on a construction site and have been placed there by the defendant. They are not being paid 'wages' in the narrow sense of that word, but are being rewarded for work produced. If they had been employed as workmen, the defendant would have been liable to pay them wages."

It is submitted, however, that $\mathrm{Mr}$. Blackwood was wrong in this interpretation and that voluntary workers are not covered by the Act. Section 3(4) states that:

"This Act shall apply only to construction work carried out by an employer on the site of the work by way of his trade or business or in the exercise of his functions or for the purpose of any industrial or commercial undertaking."

The words "... or in the exercise of his functions ..." should be interpreted in accordance with the maxim of statutory interpretation 'noscitor a sociis', i.e. general words take their colour from other words with which they are used. The other words "... by way of his trade or business ..." and "... for the purpose of any industrial or commercial undertaking" limit the definition of 'employer' to construction work carried on as a business, and the words "... or in the exercise of his functions ..." must be limited accordingly. A voluntary organisation engaged on a 'working bee' is not in business on construction work and therefore is not an 'employer' within section $3 .(4)$.

The words "or who would be so liable if men were so employed", it is submitted, cover the situation where instead of employing workmen the 'employer' does the work himself, and is required to comply with the provisions of the Act.

5.1.5 Who is_a 'bailee'?: Roper J. held in Hargreaves $v$. Mayhead Bros. Ltd. and Ferguson Construction Co. Ltd. [1971] N.Z.L.R. 559, that to transfer responsibility to the hirer of mechanical plant and therefore, for the hirer to become a 'bailee' and thus an 'employer' under section 2: 
"... it is not enough that the task to be performed is under his control, he must control the method of performing it."

The contractual relationship of the plant operator to the 'employer' is also a determining factor. Mahon J. held in Manukau City Corporation v. Safety Inspector (unreported $28.2 .79)$ that:

"The statutory definition (of employer) clearly suggests that the identity of the operator of the plant which has been hired may be a material

factor in determining whether the hirer is a bailee."

He went on to hold that if the hirer of the plant had "exclusive possession" and "unqualified power of control over the operator's activities", he was a "bailee" and, therefore, an "employer".

5.1.6 Can an 'employer' transfer liability?: Section 25 states:

"Employer may have actual offender charged:

(1) Where an employer is charged with an offence against this Act, he shall be entitled upon information duly laid by him to have any other person whom he alleges to be the actual offender brought before the Magistrate on the same charge; and to enable both charges to be heard together, the charge against the employer may be adjourned for such time as the Magistrate thinks reasonable.

(2) In any such case, if the charges are heard together and the offence is proved, but the Magistrate finds that -

(a) The offence was committed in fact by the said other person, without the knowledge, consent, or connivance of the employer; and

(b) That the employer had done all that could reasonably be expected of him to prevent the offence, -

that other person shall be convicted of the offence, and the employer shall not be guilty of the offence.

(3) If, before the commencement of any proceedings against an employer in respect of any offence under this Act, the Inspector is satisfied that if any other person were charged with the offence under the foregoing provisions of this section that other 
person would be convicted of the offence, the

Inspector shall proceed against the person whom he

believes to be the actual offender without first

proceeding against the employer."

Because of Departmental policy for prosecutions (see 4.3.3), subsection (3) is of no practical significance. Prosecutions are only approved if the Department is satisfied that the person against whom the information is laid is the offender. If subsequently it is found that another person is responsible, the information would be withdrawn and another bid against that other person.

The position is different for the 'employer' in that in some cases he and not the inspector will know whether the offence was committed by another person without the knowledge, consent or connivance of the 'employer' and, therefore, whether he should proceed against that other person under section 25 .

The following five principles are established from the cases with respect to the application of section 25 :

1. If the 'employer' doesn't charge the other person, the 'employer' impliedly accepts liability himself: Safety Inspector $v$. Archer Building Contractors Ltd. (unreported $7.10 .65)$. The employer was charged with a breach of section. 11 (b), failure to take all reasonable precautions. W. M. Willis, S.M. held that as well as employing a competent foreman, an employer is responsible for the actions of his foreman and that the employer, in omitting to lay an information under section 25 against the foreman, accepted the responsibility for the foreman's actions.

2. If the 'employer' does not supply suitable plant, gear or equipment he can not successfully charge an employee: Ross v. Associated Cement Manufacturers Ltd. [1964] 2 All E.R. 452. A charge hand steel erector was killed when he fell from a ladder while he was repairing a safety net. The House of Lords held that the respondents were in breach of the access regulations in not having provided equipment in the form of a working platform rather than the ladder and thus not having kept safe the deceased's place of work. The deceased's decision to use the ladder was reached on the basis that no suitable equipment was available. 
Similarly, the 'employer' is responsible for supplying suitable lifting equipment: Machray v. Stewarts and Lloyds Ltd. [1964] 3 All E.R. 716. The plaintiff, who was employed by the defendants, was an experienced rigger and was not able to obtain the correct lifting equipment to erect a section of pipe weighing $10 \mathrm{cwt}$. He was injured while carrying out the lift with 'makeshift' gear. MoNair J. found the defendant employer $100 \%$ liable.

3. The 'employer' can charge an employee if he deliberately disobeys instructions and creates a breach. In $\underline{\text { Ross's }}$ case Lord Reid at page 455 said that in these situations an employer:

"... can exempt himself from criminal liability under s.161 of the Factories Act 1961 (a similar provision to s.25) if he proves that he has used all due diligence and that the actual offender committed the offence without his consent, connivance or wilful default."

Lord Reid went on later to say:

"Manwaring V. Billington [1952] 2 All E.R. 747 was a case where the employer gave proper instructions to the plaintiff, but the plaintiff deliberately disobeyed them and did the work in a way which created a breach of a statutory regulation, and thus the employer was not liable."

Morris, L.J., in Manwaring at page 750 said:

"I would deem it incongruous and irrational if, on. the facts as found by the learned judge, the plaintiff could, in effect, successfully say to his employer 'Because of my disregard of your reasonable instructions I have brought about the position that you are in breach of your statutory obligations" .

4. The 'employer' can charge an employee if he would not have worn safety equipment if it had been provided: Cummings (or McWilliams) v. Sir William Arrol \& Co Ltd. [1962] 1 All E.R. 623. The plaintiff's husband, who was not wearing a safety belt, died as a result of a fall from a steel tower that was being erected. It was held that the defendant employer was not in breach of the Factories Act 1937 because if a safety belt had been provided it would not have been worn. 5. If an 'employer' delegates the job of compliance to a subcontractor, foreman or workman and after acceptance and acknowledgement fails to carry it out or does it negligently 
the employer can charge that person: Safety_Inspector $v$. Madder \& Bourne Ltd. (unreported 6.10.70). The defendant was the principal contractor for the construction of a multistorey building and was charged with a breach of regulation $31(2)$, failure to provide guard-rails in a stairwell. A New Zealand Post Office linesman was fatally injured as a result of falling down the stairwell. The Building owners had arranged for the Post Office to connect the telephone lines. The defendant charged the Post Office foreman. responsible for the gang of linesmen under s.25. J.C.K. Fabian, S.M. said that to hold the Post Office foreman liable for erecting the guard-rails was: "... beyond that which is reasonable". He held that s.25 is an indemnity, i.e. where an employer delegates the job of compliance to a person who accepts the responsibility and then fails to carry it out, s.25 transfers the liability accordingly.

\subsubsection{An 'employer' is responsible for the safety of other} persons: Construction Act Section 3(2) states:

"Any provision of this Act or of any regulations under this Act relating to the safety of workmen employed in construction work shall apply also to the safety of persons lawfully in the vicinity of the work, whether or not they are employed in the work."

Under this section a principal contractor may be liable for the safety of workmen employed by a subcontractor: McAuliffe v. Fletcher Construction Co. Ltd. [1970] N.Z.L.R. 680. The plaintiff was foreman for a painting subcontractor and the defendant was the principal contractor for building the Te Anau Hotel. The scaffolding was erected by the defendant's men and used by its carpenters and later by the painters. The plaintiff fell when a plank came off the scaffolding. It was held that the regulations had been breached and that the defendant was liable because:

"... theplaintiff was in the circumstances of this
case by reason of the combined effect of $s .22$ and
s.3(2) a person to whom the defendant owed a
statutory duty in respect of the said scaffolding."

McAuliffe was followed in Safety Inspector v. A.F. Burdon Ltd. and Wilkins \& Davies Construction Co. Ltd. (unreported 24.1.79). The first defendant was charged with a breach of 
regulation 32(1), no ladder access to a scaffold, and regulation $44(1)$, no guardrails to the scaffold. The first defendant, a painting contractor, was a subcontractor to the second defendant, the main contractor for the construction of a factory building. The scaffold had been erected by an independent contractor for the main contractor. The first defendant laid an information against the second defendant under s.25 and the actions were joined. P. J. McAloon, S.M. on the authority of McAuliffe convicted both companies. The second defendant appealed: Wilkins \& Davies Construction Co. Ltd. V. A.F. Burdon Ltd. and Safety Inspector (unreported 9.7.79), and in an undefended hearing, Ongley J. dismissed the appeal but made the following statement on s.3(2):

\footnotetext{
"In relation to work being carried out on a scaffold a person who is an employer in relation to that work by virtue of having workmen employed in it has an obligation to all others lawfully in the vicinity whose safety may be affected by non-compliance with the Act or regulations. In relation to scaffolding that will include primarily other persons using the scaffolding. He cannot be convicted of a breach in relation to such persons however unless he is himself an employer in relation to the particular construction work in respect of which the Act or regulations are involved."
}

In Madder \& Bourne's case it was held that the defendant's liability was extended under section 3(2) to include the Post Office linesman who was lawfully on the premises. However in that case there was no evidence that the defendant's men. had been working on the stairwell. In fact the defendant had erected a notice to the effect that the stairway was not to be used. It is therefore submitted that the defendant was wrongly convicted in that case.

\section{1 .8 An 'employer' is responsible for the safety of his} workmen, and must see that other employers working on the same job comply with the Act: Barlow v. Fletcher Construction Co. Ltd. and another [1963] N.Z.L.R. 952. The plaintiff's husband was employed by the third party who was a subcontractor to the defendant, the main contractor for the construction of a building. The plaintiff's husband was killed when he fell down a stairwell which did not have guardrails. It was held that under the Act each employer is responsible for the safety of 
his own workmen. Henry J. said at the foot of page 954:
"The obligation is not placed upon the particular employer necessarily to take the prescribed precautions, it is to cause the requirement to be duly and faithfully complied with. A workman is entitled to the protection of the safety device and the employer must ensure that it is there."

Barlow was followed in Safety Inspector $v$. Plastercraft Services Ltd. (unreported 7.9.78). The defendant was a subcontractor fixing plaster board walls in a building under construction. One of the defendant's workmen was injured when he fell through an inadequate landing in a stairwell. The head contractor was responsible for the construction of this landing. N. C. Jaine, S.M. convicted the defendant of failure to take all reasonable precautions, s.11(b), and failure to provide safe means of access, regulation $32(1)$. He emphasised that a subcontractor must see that the head contractor has complied with his obligations, and that a workman is entitled to look to his immediate employer for compliance. He went on to state:

\footnotetext{
"The fact that the primary obligation fell on someone other than the defendant is quite clearly relevant to the question of what penalty I should impose on this defendant."
}

The same principle was applied in the Canadian case of Regina v. Strand Electric Ltd. [1969] 1 0.R. 190. A defective scaffold erected by a third party was being used by a workman employed by the defendant. It was held, by the Court of Appeal of Ontario, that the defendant was in breach of the saffolding regulations made under the Construction Safety Act 1961 (Ontario).

\subsubsection{An 'employer' must maintain reasonable standards: $\mathrm{S} .11(\mathrm{~b})$} requires that "All reasonable precautions shall be taken to ensure the safety of workmen employed in the work".

A workman's safety is not however guaranteed: Safety Inspector v. A. Williams Construction Co. Ltd. (unreported 29.3.65). R. D. Jamieson, S.M. held that under s.11(b) an employer does not have to guarantee the safety of workmen. He said that competent men must be employed and they must to some extent guard themselves from risks which have to be accepted, by exercising their experience and skill. 
General practice is not conclusive: Hawkes Bay Farmers Meat Co. Ltd. v. Safety Inspector (unreported appeal 12.9.68). Roper $J$. in considering the standard of care required by an. employer under s.11(b) said:

"General practice has always been taken into account in determining the standard of care, but it is not conclusive, because no one can claim to be excused for want of care because others are as careless as himself [Blenkiron v. Great Central Gas Consumers Co. $(1860) 2$ F. \& F. 437]."

General practice adopted for 20 years is not conclusive: Dixon v. Cementation Co. Ltd. [1960] 3 All E.R. 417. The plaintiff was holding a piece of wood in position so that a Bllow workman could hammer a nail into it. The other workman had to lean over above the piece of wood holding the nail. The plaintiff's face was about a foot from the nail. The other workman struck the nail a hard blow, but did not strike it directly, and the nail flew out hitting the plaintiff in. the eye. The system of work had been used by the employer's workmen for some 20 years and there had been some previous occasions when some facial injuries had been caused to workmen. The Court of Appeal held for the plaintiff on the grounds that all reasonable precautions had not been taken and a safe system of work had not been adopted.

An 'employer' may not be liable if he has trained his workmen: Safety Inspector v. Poverty Bay Electric Power Board (unreported 24.11.78). A linesman was electrocuted while carrying out reticulation work on the 'Iive' side of a power pole. He was not properly clothed and the Board's safety rules were not followed. The Board was convicted under s.11(a) in that the foreman should have seen that the rules were complied with. The Charge under s.11(b) was dismissed as P. J. Rice, S.M. considered that adequate instruction and training had been provided.

An 'employer' is not an insurer: Safety Inspector $v$. Wellington City Council (unreported 13.3.79). A Iinesman was injured when a decayed wooden power pole snapped at ground level and fell across the road. The local authority was charged with a breach of $\mathrm{s.11(b)}$ in failing to take reasonable 
precautions. H. Gilbert, S.M. dismissed the information and leld that sufficient precautions had been taken in that a 'probe' test would not have disclosed the decay as there was one inch of sound timber at the circumference. The Magistrate commented on the decision of the Department in bringing the action. He said at page 4:

"... the substance of the prosecution's case seems to me to be that because there was an accident, therefore, so the argument goes, the defendant was at fault in not instituting a system of checking that would have ensured, in this case, that the defective pole was discovered before it was climbed by $\mathrm{Mr} \mathrm{Te}$ Kiris. I do not accept this approach as representing the state of the law as that seems to me to call for a counsel of perfection. It seems to me to put the defendant, as the employer, in the position of being an insurer."

An ' employer' is liable for common law duties: Safety Inspector v. Civil Civic Ltd (unreported 15.12.76). The defendant was convicted under s.11(b) for failing to take all reasonable precautions in not properly securing a cantilever scaffold platform, which collapsed, resulting in a triple fatality. K. L. Richardson, S.M. said that the decision in Safety Inspector V. A. Williams Construction Co. Ltd. (unreported 29.3.65) confirmed that the Construction Act 1959 does no more than codify what has been the employer's common law obligation for many years, i.e. the duty to take all reasonable precautions includes a responsibility to ensure that all reasonable care is taken, to devise and operate a safe system of work, to have experts carry out checks, and to keep workmen informed. He said that the standard is set by the objective assessment of the precautions to be expected of the reasonable and prudent employer in that particular sphere of activity, and is one of reasonable foreseeability at the time of the occurrence, and that the employer has a duty to look for apparent dangers. He also confirmed that under s.11(b) the onus rests on the prosecution to establish the charge of failure to take all reasonable precautions beyond reasonable doubt.

But does s.11(b) just codify the common law or does it add to the standard of care required? The word 'ensure' was defined in a similar statute in Electrical Power Transmission Pty. Lta. v. Robinson [1973] 2 Q.L. 329. Section 20 of the 
"In respect of a project on which he is engaged a constructor shall (a) ensure that the provisions of this Act are complied with or, as the case may be, are not contravened on the site."

The Queensland Industrial Court held that the word "ensure" is intended to mean "make certain" or "make sure", but that the section does not create absolute liability.

'Ensure' joined with 'shall' is an imperative statement: Regina v. Greening Industries Ltd. [1968] 1 0.R. 759. A rail supporting a crane was of inadequate strength. A regulation under the Industrial Safety Act 1964 (Ontario) required every employer to ensure that "no part of a lifting device shall be used unless it is of adequate strength". It was held that the regulation imposed strict liability. The word "ensure" joined with "shall" is an imperative statement.

'Ensure' means guarantee: Regina $v$. Westeel-Rosco Ltd. (1975) 27 C.C.C. (2d) 467. Two men were on a suspended scaffold and neither wore a safety belt, securely fastened to an independent life line, as required by a regulation made under the Construction Safety Act, 1973 (ontario). Section. 15 (3) stated that:

"A sub-contractor shall ensure that the measures and procedures prescribed by the regulations are carried out on the part of the project under his direct control."

The Ontario High Court of Justice held, affirming the conviction, that the word "ensure" carries the connotation of a guarantee and the offence, therefore, is one of strict liability.

5.1.10 An 'employer' must comply with an Inspector's

\section{Directions:}

"S.18 Directions by Inspector to ensure safety - (1) Where it appears to an. Inspector that any construction work is being carried out in such a manner as to be dangerous to any workman employed in the construction. work, he shall give to the employer for the work such directions in writing as the Inspector thinks necessary to prevent accidents, and the employer shall forthwith carry out such directions.

(2) Any directions under subsection (1) of this section may be given by the Inspector either to the employer or to any person apparently in charge of the work to which the notice relates and, if the notice is given to any such person, it shall be his duty forthwith to bring the directions to the 
notice of the employer and, within the limits of his functions as an employee, to give effect to the directions.

(3) Where an Inspector gives any directions under subsection (1) of this section, he may also, at the same time or subsequently, order any persons to cease forthwith such work in connection with the construction work as may be specified in the order until the directions are complied with, and the employer shall advise all workmen likely to be affected by the order.

(4) Every person who, without lawful excuse, -

(a) Being an employer, fails to comply with any direction or order of an Inspector under this section;

(b) Being a workman and having knowledge in any manner of any direction or order of an Inspector under this section, does any act or thing which, if done by the person to whom the direction or order was given would constitute an offence, -

commits an offence against this Act."

Directions apply to future work: Inspector of Scaffolding v. Aughton (1957) 9 M.C.D. 163 (a prosecution under the Scaffolding and Excavation Act 1922, which had similar provisions to the Construction Act 1959). A direction was given by an inspector to the defendant in July that, for the future, certain specified work might be carried out only in the manner prescribed. In November the defendant acted in defiance of this direction. J. D. Willis, S.M. held that proceedings could be taken (as they were) for the failure on November 13 to comply with the direction given by the inspector on the 24 th of July.

Directions must be specific and for dangerous work: Safety Inspector V. A. Williams Construction Ltd. (unreported 4.9.64). J. B. Thomson, S.M. held that a direction by an inspector under s.18(1) must be specific and in clear terms. In that case the direction order required the employer to perform his statutory duty to make an excavation safe and, therefore, it was held to be ultra vires. It was also held that, under s.18(3), a cease work order must refer to dangerous work only, and must relate to the specific direction under s.18(1). 
An Inspector decides what is dangerous: Inspector of Scaffolding V. Rush and Taylor (1923) M.C.R. 25 (a prosecution under the Scaffolding Inspection Act, 1908). E. Page, S.M. held that the Act throws upon the inspector, and not the court, the duty of deciding whether scaffolding was dangerous. The powers and functions of inspectors under the 1908 Act were in similar terms to those in the Construction Act 1959. Under the 1908 Act an appeal against a direction order was to the Minister whereas under the 1959 Act an appeal is to a Magistrate, s.21. It is submitted, then, that if an employer fails to appeal and does not carry out an inspector's intra vires direction he (the employer) can not argue in a subsequent prosecution that the work was not being carried out in a dangerous manner.

'Dangerous': Section 18(1) is the only section of the Act where the word 'dangerous' is used. du Parcq, J. in Walker v. Bletchley Fleltons [1937] 1 All E.R. 170 at 175 concluded that in considering whether machinery is dangerous:
"... it must not be assumed that everybody will
always be careful. A part of a machine is dangerous if it is a possible cause of injury to anybody acting in a way in. which a human being may be reasonably expected to act in circumstances which may be reasonably expected to occur."

It is submitted that although this interpretation of 'dangerous' was in that case related specifically to machinery it is an. acceptable guide for inspectors in the exercise of their discretion under s.18.

\section{1 .11 Is an employer's liability absolute}

"There is a presumption that mens rea, an evil intention, or a knowledge of the wrongfulness of the act, is an essential ingredient in every offence; but that presumption is liable to be displaced either by the words of the statute creating the offence or by the subject-matter with which it deals, and both must be considered ...":

Sherras v. De Rutzen [1895] 1 Q.B. 918 at p.921.

This passage from the judgment of Wright $J$. has been acknowledged as a correct statement of the law by a number of authorities including the Privy Council in Lim Chin Aik V. Reginam [1963] 1 All E.R. 223. In the Lim Chin Aik case Lord Evershed said at page 228: 
"Where the subject-matter of the statute is the regulation for the public welfare of a particular activity - statutes regulating the sale of food and drink are to be found among the earliest examples it can be and frequently has been inferred that the legislature intended that such activities should be carried out under conditions of strict liability. The presumption is that the statute or statutory instrument can be effectively enforced only if those in charge of the relevant activities are made responsible for seeing that the are complied with. When such a presumption is to be inferred, it displaces the ordinary presumption of mens rea."

Mahon J. in the recent case of Manukau City Corporation

v. Safety Inspector (unreported 28.2.79) concluded that section

22 of the Construction Act 1959 imposes absolute liability on the employer. He said at page 9 that:

"In the United Kingdom and in New Zealand and elsewhere in the Commonwealth the liability on an employer to observe a designated precaution stipulated in any one of the Factories Acts has normally been held to be absolute.

In Warner v. Metropolitan Police [1969] 2 A.C. 256 Lord Reid referred to the category of statutory offences under public health, licensing and industrial legislation. where it has conventionally been held that absence of mens rea is no defence, and in my opinion the Construction Act 1959 obviously falls within the category of industrial legislation so described. Then, when one looks at the text of section 22, it is observed that there is nothing to suggest that proof of mens rea is required, and one might go further and say that the terminology of the section seems itself clearly to impose absolute liability for the employer is liable unless he 'causes' the relevant requirement to be complied with or observed. Thus the concept of vacarious liability is dispensed with and also the related but different questions as to whether the servant or agent committing the quasi-criminal default is to be identified with the company or corporation which has been prosecuted for the relevant statutory offence."

Mahon J. continued:

"If I am wrong in construing section 22 literally, then there is a principle which in any case seems conclusive against the argument for the Appellant. The principle I have in mind is that stated by Lord Reid in Sweet $v$. Parsley [1970] A.C. 132 when he said, at p.149: 


\author{
"It has long been the practice to recognise \\ absolute offences in this class of quasi-criminal \\ acts, and one can safely assume that when \\ Parliament is passing new legislation dealing \\ with this class of offences, its silence as to \\ mens rea means that the old practice is to \\ apply ."
}

The principle so expressed seems, in my opinion, plainly to be applicable here. The safety requirements contained in the Construction Act and also in the Construction Regulations 1961 and also in any other Regulation or enactment falling within the description stated in section $11(\mathrm{f})$, are aimed at the prevention of death or injury to workmen and other persons engaged in or about construction work. In that class of legislation the liability of a person in breach of the safety provisions has conventionally been held to be absolute, in the absence of any defined excuse based on practicability, it being no defence that the defendant could not, by the exercise of reasonable care, have known or discovered that a danger in fact existed or that his premises were unsafe or that danger was imminent. The legislation has been construed as involving the proposition that the defendant must take the risk, and if it is found that he has infringed the statutory prohibition or requirement then he must pay the penalty prescribed for the quasi-criminal of fence.

In enacting the Construction Act 1959 the legislature must be presumed to have had in mind the cognate legislation dealing with safety of workmen in factories and the absolute duties placed upon occupiers of factories and workshops.

Examples of that type of legislation in New Zealand are the Factories Act 1946 and the Machinery Act 1950. Mandatory provisions relating to the safety of workmen have been enacted in those statutes in terms which are absolute. The only possible qualification may be found in one or two of the provisions under the Factories Act 1946, for example in section 47, where there is a duty to provide and maintain safe means of access and a safe place of employment 'so far as is reasonably practicable'. But even there, the exculpatory clause only entitles an employer to excuse compliance with a duty otherwise absolute upon the grounds that it was not reasonably practicable to do so, a situation which does not amount to requirement of proof of mens rea. Section 22 of the Construction Act 1959 contains no reference to 'reasonable practicability' and the presumption is that the legislature, in the interests of preserving the safety of people in or about construction sites, refrained from introducing any exculpatory clause, and intended the employer's duty to be absolute in conformity with the general pattern of industrial legislation aimed at securing the safety of workmen and other persons. 
In these circumstances the duty imposed by section 22 is in my opinion both literally and inferentially absolute, and absence of mens rea is no defence."

It is respectfully submitted that there are at least two exceptions to Mahon. J.'s findings that the employer's duty is absolute under section 22 of the Construction Act 1959, i.e. when an employee is in breach and for property damage.

1. Employee in breach: Lord Reid in Boyle v. Kodak Lta. [1969] 2 All E.R. 439 pointed out that the absolute liability principle can lead to 'absurd results' in the employment situation. The plaintiff in that case was a painter employed by the defendant and he fell while climbing a ladder to lash it at the top. He was not aware that the regulations required that the ladder should be lashed before using it. on a claim for breach of statutory duty it was held that an. employer, to avoid liability, must show that he has complied with his statutory duty by taking all reasonable steps to prevent his employees from committing breaches of the relevant regulations. Lord Reid said at page 440:

"The doctrine of absolute liability, which was invented by the courts, can lead to absurd results when coupled with the employer's vicarious liability. It would be absurd if, notwithstanding the employer having done all he could reasonably be expected to do to ensure compliance, a workman, who deliberately disobeyed his employer's orders and thereby put the employer in. breach of a regulation, could claim damages for injury caused to him solely by his wrongdoing. So the courts have quite properly introduced a qualification of the employer's absolute liability. A principle of law has been established that, although in general the employer is under absolute liability in respect of such a breach, the employer may have a defence to an action against him by an employee who is also in breach."

This principle was further examined in H. Buckman \& Son Pty. Ltd. v. Flanagan (1974) 4 A.L.R. 465 and Mason J. said, at page 480 , that the rule is seen:

"... as one which specially limits the liability of a defendant who has delegated to the plaintiff the performance of a task which imposes upon each of them a statutory obligation in the breach of which the plaintiff is solely at fault. Yet, although denying a liability in the defendant, it concedes that he is in breach of his duty and regards the breach as nonactionable because it came about solely in consequence of the plaintiff's fault." 
Although not stated as such the principle was applied in Safety Inspector v. Mervyn John Carroll (unreported 27.7.73). J. D. Kinder, S.M. held that where scaffolding is used without the knowledge of the defendant (the employer) the legislature could not have intended that the defendant would be responsible for breaches of the scaffolding regulations.

2. Property damage: Included in the Construction Act 1959 and the regulations are various provisions for the protection of services and property. It was held in New Plymouth Borough v. Rope Construction Co. Ltd. and another (1962) 10 M.C.D. 447 that an employer's duty is not absolute for these offences. In that case the defendants were under contract to the New Zealand Railways to construct a bridge and while using explosives damaged the plaintiff's sewer pipes. Mr A. W. Yortt, S.M. held that section 12 of the Construction Act 1959 is primarily concerned with the safety of workmen and before a defendant can be held liable for damage to property, through breach of subsection $12(d)$, he must be shown to have been guilty of a wilful or negligent disregard of its provisions. It is arguable whether Mr. Yortt is correct in this interpretation. Section $12(d)$ is concerned with the interuption to services, and the social and economic costs and implications of breaking a coaxial communications cable, a main sewer, gas, water, electricity, or other service, may far outweigh the comparable costs of a breach of a minor safety provision. 5.1.12 Absolute liability in Canada: The Canadian decisions have not been uniform. Nevertheless an analysis of the relevant cases dealing with construction safety law is included to provide authority in particular work situations and as a lead on to the development of the 'three category' concept of offences.

Absolute liability for 'welfare' statutes: Queen V. Pierce Fisheries Ltd. (1970) 5 C.C.C. 193. This case dealt with a statutory prohibition for catching under-sized crayfish The supreme Court of Canada made the bald statement that regulations made for individual conduct in the interests of health, convenience, safety and the general welfare of the public impose absolute liability. 
Absolute liability when hiring out unsafe machines:

Regina v. Sam Consentina Ltd. [1965] 2 0.R. 623. The Ontario Court of Appeal held that s.19a of the Construction Safety Act, 1961 (Ontario) absolutely prohibits the hiring out of unsafe machines and that it is immaterial that the person providing the equipment which was obtained from and operated by a third party was unaware that it was defective.

Liability is not absolute if an employee does not wear safety equipment: Regina ․ A. O. Pope Limited (1972) 20 C.R.N.S. 159. Goggles had been made available by the employer but a workman failed to wear them. The New Brunswick County Court held that the Industrial Safety Act, 1964 (N.B.) does not impose absolute liability. It is sufficient if the employer provides the equipment.

Strict liability when structural material is over stressed: Regina v. Amherst Crane Rentals Ltd. (1975) 26 C.C.C. (2d) 477. The bolts holding concrete panels to the outside of a building under construction were underdesigned and failed. The bolts were supplied by a manufacturer and were not tested by the defendant sub-contractor. A regulation made under the Construction Safety Act, 1973 (Ontario) required that the allowable stress on any material shall not be exceeded. It was held that the Act imposed strict liability and that mens rea was not required. Queen $v$. Pierce Fisheries Ltd. was followed.

Standard of 'negligence' for failure to take reasonable precautions: Regina v. V.K. Mason Construction Ltd. [1968] 1 0.R. 399. The bottom fell out of a tool box, while being lifted by a crane, resulting in injury to a workman. The defendant contractor was convicted for a breach of section $18(3)$ of the Construction Safety Act 1961 (Ontario) for failure to take reasonable precautions to ensure the safety of all persons on the project. The High Court of Justice Ontario held, affirming the conviction, that section 18(3) does not require mens rea nor does it impose strict liability. It imposes responsibility for negligence.

Flynn J. in Regina v. PPG Industries (unreported 15.6.78 in the Saskatchewan Magistrates' Court) concluded that offences under public welfare statutes can be grouped into three categories. He said at page 3 of his judgment that: 
"I think that the law with regard to this particular type of offence is now quite clear. In the recent case of Caswell v. The Corporation of the City of Sault Ste. Marie, an unreported decision of the supreme Court of Canada, Mr. Justice Dickson dealing with the matter before that Court states:

"I conclude, for the reasons which I have sought to express that there are compelling grounds for the recognition of three categories of offences rather than the traditional two:

1. Offences in which mens rea, consisting of some positive state of mind such as intent, knowledge, or recklessness, must be proved by the prosecution. either as an inference from the nature of the act committed, or by additional evidence.

2. Offences in which there is no necessity for the prosecution to prove the existence of mens rea; the doing of the prohibited act prima facie imports the offence, leaving it open to the accused to avoid liability by proving that he took all reasonable care. This involves consideration of what a reasonable man would have done in the circumstances. The defence will be available if the accused reasonably believed in a mistaken set of facts which, if true, would render the act or omission innocent, or if he took all reasonable steps to avoid the particular event. These offences may properly be called offences of strict liability.

3. Offences of absolute liability where it is not open to the accused to exculpate himself by showing that he was free of fault."

Flynn $J$. went on to hold that the requirement in section 3(a) of the Saskatchewan Occupational Health and Safety Act, 1977:
"Every employer shall ensure, insofar as is reasonably practicable, the health, safety and welfare at work of all his workers."

squarely places this offence within the second category. He said at page 4 that:

"I am satisfied that there is nothing in the statute that implies mens rea. For that reason. I find this to be a case of strict liability, one where all that is necessary is that the Crown proves the prohibited act which prima facie imports the offence. It leaves the defence an opportunity to prove, and the burden of proof is on the defence, to prove that he took all reasonable precautions to avoid it or the defence of due diligence as it is sometimes referred to." 
It is submitted that the recognition and development of this 'three category' concept of offences would assist industry and all those involved with safety law in the understanding and the application of the various provisions in the legislation.

5.2 Safety Supervisors: An employer must appoint a safety supervisor on any notifiable work if he (the employer) is unable to exercise personal supervision himself .. s.9(1), and the employer must advise all his workmen employed on that work who is the safety supervisor. The safety supervisor's duty is to ensure that the safety provisions of the Act are complied with, and he must report any breach or defect to the employer ..s.9(7). But s.9(9) makes it plain that the liability of an employer is not affected by any failure of a safety supervisor to exercise his functions. Two or more employers may appoint the same safety supervisor on the site .. s.9(11). Regulation $97(7)$ requires that safety supervisors must obtain the appropriate certificate of competency for the particular notifiable work.

An employer may require a certificate of competency: Safety Inspector v. Commercial Concrete Ltd. (unreported 26.7.73). A charge was laid for a breach of regulation $97(7)$, failure to provide a certificated safety supervisor on notifiable work. P. J. Trapski, S.M. held that under 5.9 if an employer himself intends to carry out the functions of a safety supervisor he must hold the appropriate certificate of competency.

A safety supervisor is required from the start of notifiable work: Safety Inspector v. Special Coatings (N.Z.) Ltd. (unreported 23.3.79). The defendant was charged with and convicted of breaches of regulations $32(1)$, and $44(2)$, but the charge that the work was not notified, and that no safety supervisor was appointed was dismissed. J. W. Dalmer, S.M. held:

"... the defendant company was not obliged at the beginning of the contract to give notice that at some future time it might be required to carry out work which was notifiable."

With respect, the Magistrate was clearly uninformed in that he did not consider the Construction Amendment Act 1977 which provides for notification of work which will at any time include notifiable work. 
5.3 Workman: is defined in s.2 as:

"... any person engaged in any capacity in construction work; and includes an apprentice and an employer when engaged in the performance of any such work."

The only specific duties of workmen laid down in the Act are contained in three sections. Firstly, in s.11(f), the workman, as well as the employer, is required to comply with the provisions of any enactment making provision for the safety of persons engaged in any construction work. Secondly, in s.18(4), a workman is required to comply with any order or direction of the inspector. Thirdly, in s.23 a workman commits an offence if he is employed by an employer and fails to comply with the Act, or without reasonable cause endangers himself or others, or wilfully or negligently disregards instructions for securing observance of the Act.

In the regulations there are 3 specific requirements for 'workmen', 1 for 'employees', and $?$ for 'persons' (which obviously include workmen). Workmen must wear goggles supplied by the employer, where there is a special risk of injury to their eyes, reg.33. Workmen must not walk over or work on any brittle roofing material unless there is adequate support directly under the roofing, reg.34A(1). Workmen must not, knowingly, use on construction work any powder-powered tool which is defective and dangerous, or use such a tool in. an unsafe manner, reg.96.

Part XIV of the Gas Supply Safety Regulations were incorporated into the Construction Regulations in 1971, and the word 'employees' in regulation 117 should have been changed to 'workmen'. The requirement is that employees must wear safety equipment when engaged on work in connection with mains containing gas under pressure.

Every person who enters a protective helmet area must wear a head protective helmet, reg.32A(2). Persons are not permitted to work on a gas supply system without training (reg.113). Every person must comply with the codes of practice for Underwater Diving (reg.118), Work in Compressed Air (reg.119), Scaffolding (reg.36A), and Excavations (reg.70A). Persons must not breach the explosives regulations (reg.104).

Except for s.?(4) there is no offence creating provision for 'persons'. However, there is no doubt that 'persons' include 'workmen', as well as 'employers'. 
A night watchman is a 'workman': Field v. Perrys (Ealing) Ltd. [1950] 2 A1l E.R. 521. Devlin J. held that a night watchman, who was injured when he tripped over a loose plank while doing his rounds at night, was a 'workman', and his employer was in breach of the regulations.

5.4 Crown Liability: Section 32 of the Construction Act 1959 states that: "This Act binds the Crown."

In the recent case of Southland Acclim. Society v. Anderson [1978] 1 N.Z.L.R. 838, the Society charged the Mines Department, and the Minister of Mines who was the holder of a water right issued pursuant to Section 23 of the Water and Soil Conservation Act 1967, with failing to comply with a condition of that water right. On the informations coming before the magistrate counsel for the defendants raised the preliminary objection that there was no jurisdiction for him to hear them. This objection was upheld by the magistrate who declined jurisdiction. The Society applied to the Supreme Court under section 4 of the Judicature Amendment Act 1972 for a review of this decision and sought an order that the Crown was bound by the penal provisions of the Water and Soil Conservation Act 1967, and a declaration that the Magistrate's Court had jurisdiction to determine a prosecution against the Crown in respect of a breach of that Act, section 3 of which states that, "This Act shall bind the Crown".

Quilliam J. dismissed the application and held that: 1. It is possible for a statute to contain provisions for the Crown to become criminally liable ... Cain v. Doyle (1946) 72 C.L.R. 408, and Canadian Broadcasting Corporation V. A.G for Ontario (1959) 16 D.L.R. (2d) 609.

2. The expression 'every person' contained in section 34 of the Water and Soil Conservation Act 1967, which is the offence creating provision, does not include the Crown.

3. The offences created by the Water and Soil Conservation Act 1967 are summary offences and the only machinery for bringing an action before the court is that provided by the Summary Proceedings Act 1957, and as this Act does not bind the Crown, there is no jurisdiction for a magistrate to entertain an information against the Crown. 
A prosecution policy has been established under the Construction Act 1959, one arm of which requires that court action proceed where a fatality or serious injury accident occurs, and it is associated with a breach of the Act. Government Departments employ large work-forces to carry out construction work and the number of fatal and other serious accidents to Government employees has been increasing in recent years. Of the 100 fatalities over the last four years, 20 have been. Government employees. Of these 20, at least 10 were associated with a breach of the Construction Act 1959 and if they had been employees of private contractors prosecutions would normally have proceeded.

From time to time consideration has been given to prosecuting the Government engineer in charge of a workman killed, by laying an information against the engineer as a 'workman', under section 23 of the Construction Act 1959. However, there is an element of unfairness in that the engineer is required to pay court costs and his own legal expenses as well as any penalty imposed and he may have been only partially responsible.

The solution to this problem is to make provision in the Construction Act 1959 for laying informations against Government Departments. This course has been recommended by the Public Service Association. (See P.S.A. Newsletter 21 November 1978 , page 280.)

It is true that this would result in the Crown paying a fine to itself and that the crown has the power to remit the fine. But as pointed out by Benjafield and Whitmore, Australian Administrative Law, 3rd ed. 1966 page 306, this does not make the prosecution self-defeating. Each Government Department has its own separate annual appropriation of funds and its own accounts. The recording of a judicially imposed fine within those accounts would in itself be a deterrent and it would provide the opportunity for the matter to be raised at Ministerial level and in Parliament.

To provide for prosecutions against Government Departments, on the authority of the Southland Acclim. Society. case the Construction Act 1959 would have to be amended, firstly, to 
define "Government Departments", secondly, to include Government Departments within the definition of "employer", and thirdly, to provide that the Summary Proceedings Act 1957 applies to Government Departments so that the charge can be heard in the Magistrate's Court.

1. Definition of "Government Department": The definition of "Government Department" in section 2 of the Water and Soil Conservation Act 1967 should be added to section 2 of the Construction Act 1959:

"Government Department" means every Department or instrument of the Executive Government of New Zealand.

2. Government Departments as Employers: Quilliam J. in the Southland Acclim. Soc. case held at page 842 that:

"In the Water and Soil Conservation Act there is no definition of "person" and the general definition of s.4 of the Acts Interpretation Act 1924 will apply. That provides that person includes a corporation sole and also a body of persons whether corporate or unincorporate."

He went on to hold that "person" was never intended to be so all-embracing as to include the Crown. The definition of "Employer" in section 2 of the Construction Act 1959 includes the words: "... means any person who is liable for the payment of wages ...".

There are, therefore, at least two amendments that would make Government Departments employers under the Construction Act 1959. Firstly, the words "or Government Departments" could be added after the words "person" in the definition of "Employer", or secondly, "Person" could be defined in the Act. This second alternative is favoured on the grounds of clarity. Therefore, the following definition should be added to section 2 :

"Person" includes a Government Department, a corporation sole and also a body of persons whether corporate or unincorporate.

3. Summary Proceedings Act 1957: Quilliam J. in the Southland Acclim. Soc. case held at page 843 that:

"The offences created by the Water and Soil Conservation Act are summary offences and the only machinery for bringing them before the court is that provided by the 
Summary Proceedings Act 1957. That Act does not bind the Crown. As I have mentioned earlier, the Crown cannot be bound, whether civilly or criminally, except by express statutory provision."

However, the Summary Proceedings Act 1957 does not expressly exclude the Crown or instruments of the Crown. Therefore if it is made clear in the Construction Act 1959 that "Government Departments" can be proceeded against summarily, then, the "express statutory provision" will have been met.

Therefore the following words should be added after the word "complaint" in section 26(1): "against any person".

5.5 Liabilities of Local Authorities and Public Corporations: It is clear that when such bodies carry out construction work with their own work-force that they are "employers" within the Construction Act 1959 and have the same responsibilities and liabilities as any other employer.

5.6 Liabilities of Inspectors: One of the functions of a construction safety inspector under section 6 of the Construction. Act 1959 is to advise on safe practices.

In Dutton v. Bognor Regis United Building Co. Ltd. \& another [1972] 1 All E.R. 462, Lord Denning M.R., at page 473, stated that:

"... in the case of a professional man who gives advice on the safety of buildings, or machines, or material, his duty is to all those who may suffer injury in case his advice is bad."

And in Anns V. London Borough of Merton [1977] 2 A11 E.R. 482, Lord Wilberforce in a judgment concurred in by Lords Diplock, Simon and Russell stated the duty of care at page 498 as follows:

"Through the trilogy of cases in this House, Donoghue v. Stevenson [1932] A.C. 562, Hedley Byrne \& Co. Ltd.v. Heller \& Partners Ltd. [1964] A.C. 465, and Home Office v. Dorset Yacht Co. Ltd. [1970] A.C. 1004 , the position has now been reached that in order to establish that a duty of care arises in a particular situation, it is not necessary to bring the facts of that situation within those of previous situations in which a duty of care has been held to exist. Rather, the question has to be approached in two stages. First, one has to ask whether, as between the alleged wrongdoer and the person. who has suffered damage, there is a sufficient 
relationship of proximity or neighbourhood such that, in the reasonable contemplation of the former, carelessness on his part may be likely to cause damage to the latter, in which case a prima facie duty of care arises. Secondy, if the first question is answered affirmatively, it is necessary to consider whether there are any considerations which ought to negative, or to reduce or limit the scope of the duty or the class of person to whom it is owed, or the damages to which a breach of it may give rise (see Dorset Yacht case, per Lord Reid)."

It is clear that an inspector has a duty of care in the exercise of his statutory functions, and he must not offer any advice unless his own experience and knowledge is sufficient to be certain that the information is sound and correct. Although the Accident Compensation Act 1972 removes any claim for civil damages for personal injury that might arise as a result of negligent or wrong advice an inspector would certainly be liable in such circumstances for property damage. A construction safety inspector is usually well trained and is an experienced expert in his field but it cannot be expected that he is knowledgeable in all aspects of construction, e.g. in engineering design matters. Therefore, he must err on the side of restricting his advice to those subjects within his competence, experience and knowledge.

5.6.1 Priviledged information: Under section $?$ inspectors have the power of entry onto all construction sites. But until 1978 an inspector was not permitted to disclose any information acquired in the course of his work. It was held in Eggers v. E. D. Wilson Construction (Nelson) Ltd. [1974] N.Z.L.R. 901 that such information obtained by an inspector was priviledged and could not be produced in court in a civil damages case. However the Construction. Amendment Act 1978 has provided for disclosure after obtaining the consent of the Minister or on the request of a coroner.

5.7 Liabilities of Consultants and Experts: Other specialists are liable for negligent or bad advice in the same way as construction safety inspectors. They may also be liable for a breach of statutory duty if they have actual responsibilities on the site. Thus in Driver v. William Willett (Contractors) Ltd. and another [1969] 1 All E.R. 665, the plaintiff was employed as a general labourer on a building site and was seriously injured when a scaffold plank fell from a hoist. 
The employers were in breach of their statutory duty in permitting the hoist to be used in an unsafe manner. The employers had entered into a contract with a firm of consulting safety and inspecting engineers to advise them on safety requirements and compliance with the regulations. The effect of this contract was that the consultants undertook the duties of a safety officer under the regulations, and they had not advised the employers to discontinue the unsafe use of the hoist. Rees J. held that the consultants, as well as the employers, were in breach of their statutory duty. 

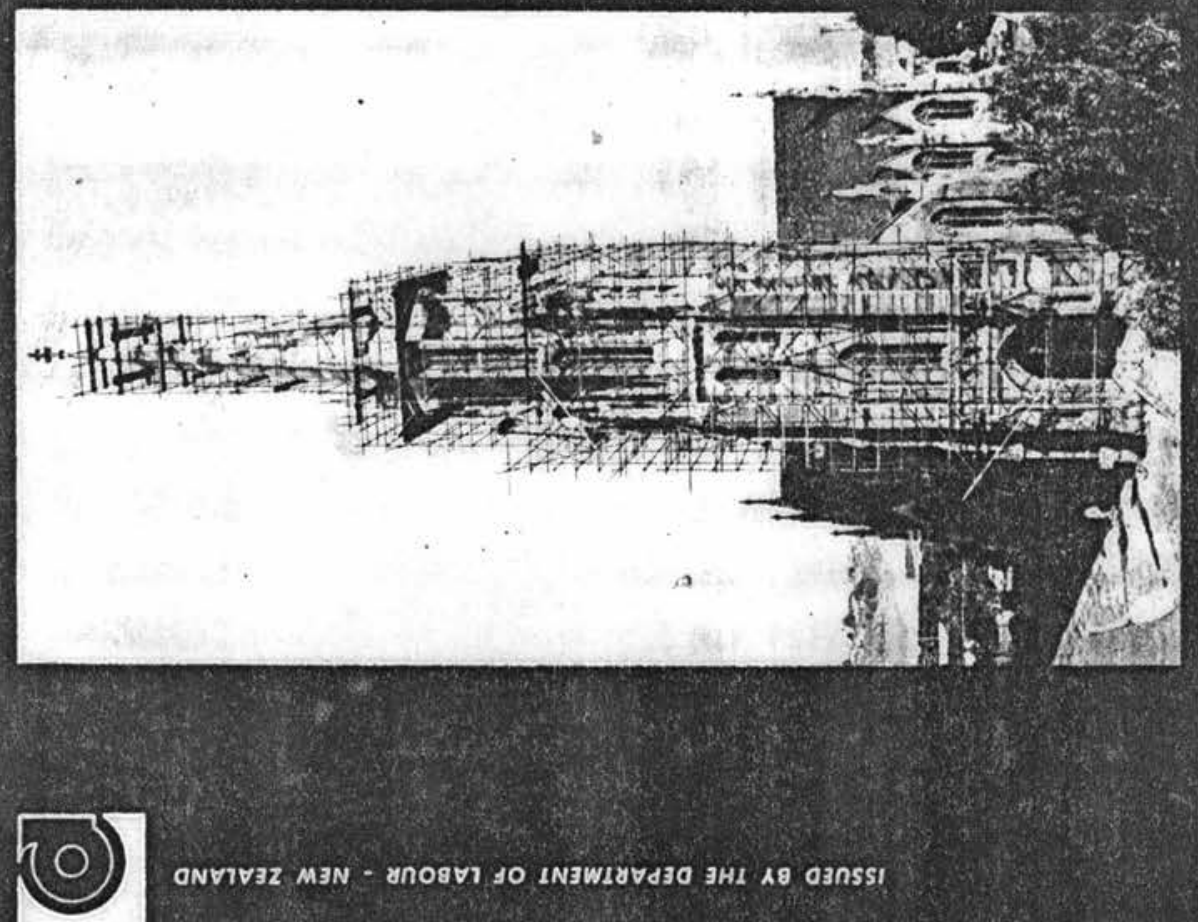

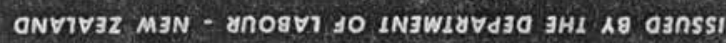
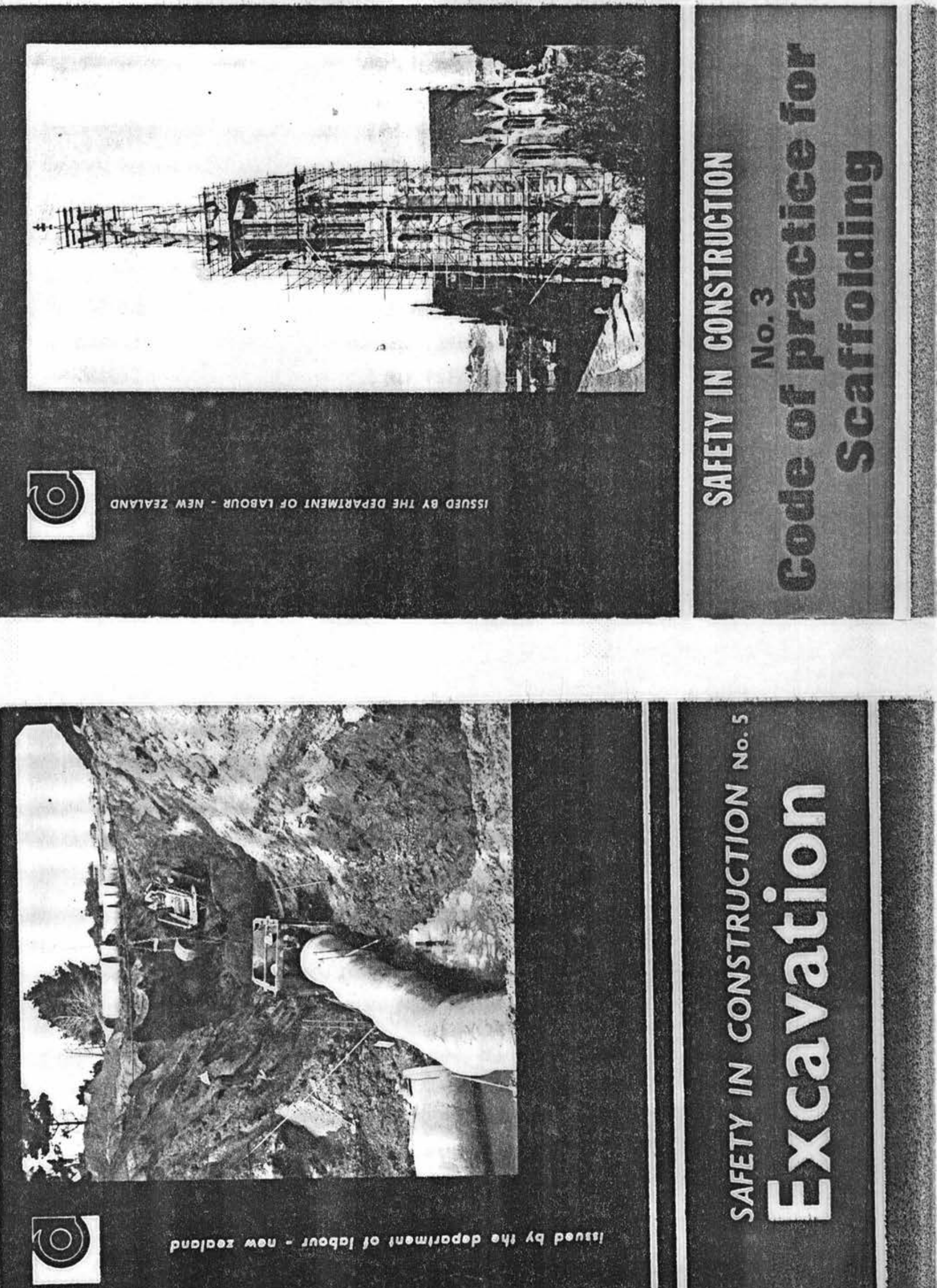

puppos MOU - inoqel 10 juowjedop oys Aq penssl

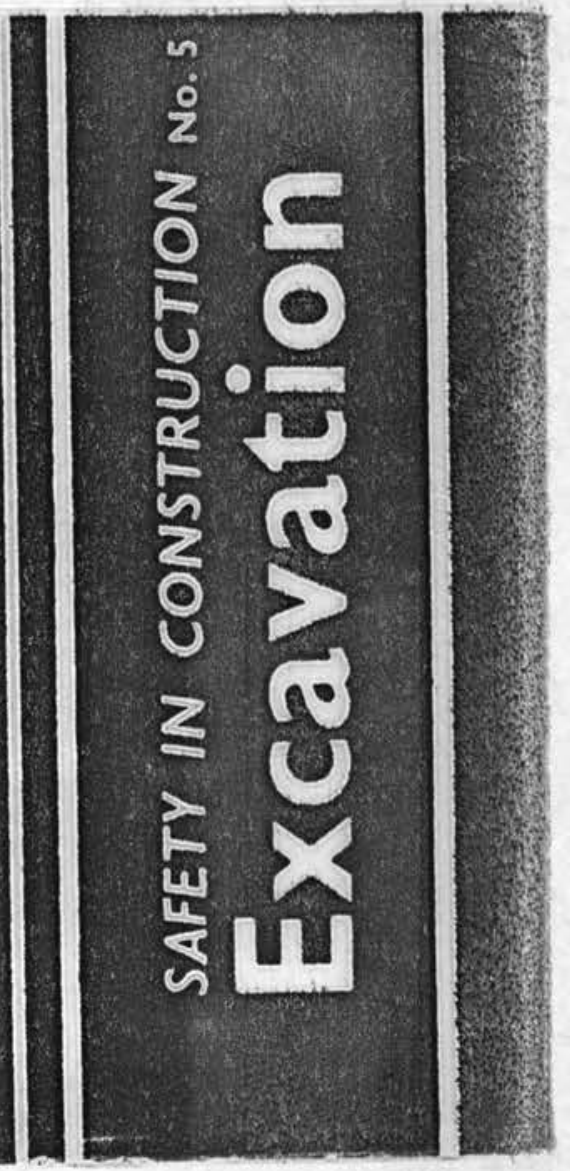


6. Technical Law

The relevant New Zealand, English, Australian and

Canadian cases have been analysed and are presented under the various technical subject headings. Unless stated otherwise the requirement in the Act or regulations in each particular overseas case is similar to that in the New Zealand Construction Act 1959 or the Construction Regulations 1961.

\subsection{Scaffolding}

6.1.1 Erecting and dismantling: The most important case on dismantling is Sexton v. Scaffolding (Great Britain) Ltd. [1952] 2 All E.R. 1085. The plaintiff was one of three employees of the defendant who were dismantling tubular scaffolding. One of the employees ordered the removal of a guardrail and the paintiff accidentally fell some 20 feet. The Court of Appeal held that guardrails were not required to protect scaffolders erecting or dismantling scaffolding. The same principle was applied in Moloney v. A. Cameron Ltd. [1961] 2 All E.R. 934. In that case the plaintiff, a painter, fell from a trestle scaffold while assisting to erect a platform. The Court of Appeal affirmed Sexton and held that the regulations requiring scaffolds to be properly maintained and secured do not apply to embryo scaffolds as distinct from completed scaffolds. The New South Wales Supreme Court held in Lambert v. Thiess Bros. Pty. Ltd. (1965) 84 W.N. Pt. 1 N.S.W. 97 that the New South Wales scaffolding regulations do not require 'suitable and safe' scaffolding for men who are erecting scaffolding. However, in Moore v. Concast Pty. Ltd. [1972] 2 N.S.W.L.R. 687 the New South Wales Court of Appeal, without reference to the English cases, overruled Lambert and held that guardrails are required for persons erecting scaffolding.

It is submitted that Moore is incorrect because in the practical situation of erecting or dismantling scaffolding it is impossible to meet all the requirements. The regulations in each of the jurisdictions, including New Zealand, are designed for the safety of workmen on completed scaffolds and not for erection or dismantling. 6.1.2 Working on planks: The Western Australian Supreme Court held in Merlino v. Australian Wheat Board (1943) 45 W.A.L.R. 12 that planks are a 'working platform' and therefore guardrails are required. A workman fell from planks while 
Wheeling a barrow of concrete and guardrails should have been provided on the sides of the planks. In Byers v. Head Wrightson \& Co. Ltd. [1961] 2 Al1 E.R. 538 an improvised plank bridge was held to be a 'scaffold'. The plaintiff was injured when he and two other workmen employed by the defendant attempted to man-handle a welding machine across an inadequate temporary bridge over a trench. The bridge was made with three planks placed in position by the workmen and it was held, by Elwes J. in the Queen's Bench Division, to be a 'scaffold' and was not constructed to the requirements of the regulations. 6.1.3 Width of working platforms: A painter's bucket of distemper and his brush was held to be 'materials' in Cork V. Kirby Maclean Ltd. [1952] 1 All E.R. 1064. A painter employed on distempering the roof inside a building was working on a platform 27 inches wide and 23 feet above the floor and from time to time he placed his bucket and brush on the platform. It was held, by Donovan J. inthe Queen's Bench Division, that the platform should have been 34 inches wide because 'material' was deposited. The New Zealand Construction regulation 43(7) requires that the width of the decking of any working platform shall be not less than $600 \mathrm{~mm}$, provided that where it is intended to deposit materials on the platform, the width shall be sufficient to ensure an unobstructed space not less than $450 \mathrm{~mm}$ wide along the whole length of the platform, provided also that where a light-duty working platform is used intermittently and workmen are not required to deposit material on the platform, the decking may consist of a single plank not less than $225 \mathrm{~mm}$ wide. The single plank scaffold has traditionally been used by painters in New Zealand but the decision in Cork means that a painter's paint tin and brush could be regarded as 'material' if it is deposited on the platform from time to time. Therefore the decking on painter's scaffolds should be not less than $600 \mathrm{~mm}$ wide, i.e. 3 planks.

6.1.4 Ladders: In Chatfield v. South Brisbane Gas \& Light Co. Ltd. [1969] Q.W.N. 45 it was held that a ladder was not suitable for carrying out work using an oxy-acetylene torch. The plaintiff, a boilermaker, was instructed by the foreman to use a ladder to do work with an oxy-acetylene torch. The ladder slipped and he fell. The Queensland Supreme Court concluded 
that the defendant was in breach in not supplying the plaintiff with a 'working platform'. Similarly a 7 foot step-ladder was held to be not suitable for pointing up joints in slabs 11 feet from the ground under a ceiling in Nielson $v$. P. J. Lowther \& Son Pty. Ltd. [1971] Qd. R. 92. The plaintiff, a 23 year old apprentice stonemason, fell backwards from the ladder. The Queensland Supreme Court stated that the defendant should have supplied a 'working platform'. These two cases indicate that working from a ladder is unacceptable when using equipment such as welding, grinding and drilling tools, and when working on ceilings. Both hands are required for this kind of work, and in the former case, the equipment adds to the instability, while in the latter, it is the continuous looking up which provides the additional insecurity.

The High Court of Australia concluded in Duyvelshaff $v$. Cathoart \& Rithie Ltd. [1973] 1 A.L.R. 125 that whether a 'working platform' or a ladder is required depends on the specific work. The appellant, a plumber, fell 20 feet from a plank while joining 2 pipes fixed to the wall of an air-conditioning shaft in a building. It was held that there was no breach of the scaffolding regulations which merely prescribed the form which 'working platforms' should take if and when an employer chooses to use them. A ladder had been made available to the appellant and he should have used it in this case rather than the insecure plank. However in Tanti v. L. L. Constructions Pty. Ltd. (1972) 20 F.L.R. 10 the plaintiff, a skilled labourer, fell while climbing boxing to tighten some bolts. It was held, by the Supreme Court of the Australian Capital Territory, that the defendant was in breach of the scaffolding regulations and that in elevated positions the employer must provide suitable means of securing the safety of workmen. It is not enough to have ladders and other equipment available.

The British regulations require that ladders, so far as is practicable, should be fixed at the top before they are used. The Court of Appeal in o'Brien V. U.D.E.C. Ltd. (1968) 4 K.I.R. 449 held that the employer was in breach of this regulation. when the ladder slipped while the plaintiff was climbing it in order to fix it at the top. However the House of Lords held in Boyle v. Kodak Ltd. [1969] 2 All E.R. 439, that an employer can avoid liability by instructing his workman that the ladder must be tied at the top before he ascends. The facts and the 
result in this case were the same as in o'Brien (see para.5.1.11 Exceptions to absolute liability). There is no equivalent regulation in New Zealand, nevertheless it is accepted that a long ladder should be tied at the top before ascending when this is possible.

In Garner v. John Thompson. (Wolverhampton) Ltd. (1968) 6 K.I.R. 1, the plaintiff, a welder, fell from a ladder while welding a tank inside a building. The Court of Appeal held that the plaintiff had established by the fact that the ladder had slipped that it was prima facie unsafe and so the onus of proof shifted to the defendants to show that it was as safe as it was reasonably practicable to make it, and since the defendants did not call any evidence they had failed to discharge the onus of proof which lay upon them. This decision would be relevant if an employer charged a workman under section 25 of the New Zealand Construction Act 1959.

\subsection{Guardrails at Perimeters and Openings: The New Zealand} Construction Regulation 31 (2) requires that:

\footnotetext{
"Perimeters of working places, openings in floors, walls, roofs and stairwells shall, while construction work is being carried out, be provided with a guardrail or a toeboard, or both, if any danger exists of a fall of persons or materials."
}

The regulations in Britain, Australia and Canada are in similar terms, and in Westcott v. Structural and Marine Engineers Ltd. [1960] 1 All E.R. 775, it was held that the regulations had been breached when the plaintiff fell of a concrete roof which did not have guardrails. Similarly, guardrails should be provided when a flat roof is being constructed: Kelly v. Pierhead Ltd. [1967] 1 All E.R. 657. Kelly was constructing a flat roof on a one-storey projection to a large main building. No guardrails were provided and Kelly fell from the roof and was killed. The Court of Appeal held that Pierheads were in breach of the regulations. The flat roof was a 'working place' and since it had the same relevant characteristics as a 'working platform' notwithstanding the absence of precise boundaries, these characteristics being that men would be working there for an appreciable time, that it was flat and that its total area was sufficiently defined and not too large, guardrails were required. In Ferguson v. John Dawson \& Partners (Contractors) Ltd. [1976] 3 All E.R. 817, the Court of Appeal concluded that guardrails were required on a flat roof for only ten minutes work. 
The plaintiff, while throwing scaffold planks from a flat roof to the ground, fell over the edge. It was held that the regulations were breached in that no guardrails were provided. The 10 or 15 minutes required for the plaintiff's intended work was an appreciable time and accordingly the flat roof was a 'working place'.

Guardrails were not required, however, when working on a sloping roof: Gill v. Donald Humberstone \& Co. Ltd. [1963] 3 All E.R. 180. The appellant who was employed by the respondents was working on the sloping roof of a hut applying creosote to the felt covering. Two ladders fastened together at the top lay across the apex of the roof one resting on each side. The appellant, standing on one ladder, worked on one side of the roof and another workman worked on the other. Preparatory to moving the ladders the appellant put a foot off his ladder and he slipped and fell. There were no guardrails around the roof. The House of Lords held that there was no breach of the regulations which required a guardrail on the side of a 'working place' and that the appellant had no 'working place' while he was working on the roof. 'Working place' was restricted to a place similar to and having like characteristics to those of a 'working platform'. Lord Reid at page 182 said:

"The typical working platform appears to be a
comparatively small temporary structure or
contrivance on which a man can stand, or I
suppose sit or kneel, when working on a
building, at some distance above the ground."

6.2.1 Openings: Floors should be free of traps: Rice $v$. Henley (1914) 19 C.L.R. 19. The plaintiff fell through an opening in the 3rd floor of a building under construction. Regulation 20 made under the Scaffolding and Lifts Act 1912 (N.S.W.) required:

"... all well-holes and similar openings in floors to be effectively guarded."

The High Court of Australia held that the word 'floors' means parts of buildings intended to be walked upon and in a stage of construction when ordinary persons would think that they might walk about on them safely without finding a trap. 
If instead of guardrails, covers are used, they should be fixed in place: Rigter v. J. C. Taylor Constructions Pty. Ltd. (1974) 9 S.A.S.R. 282. Regulation 16(1) made under the South Australian Construction Act, 1967 required that:

"... every opening which could contribute to the injury of any person, and which is left in any floor where work is proceeding, shall be securely protected so as to safeguard persons from falling."

Regulation $16(2)$ required that:

"... every cover shall be so constructed as to securely cover the opening."

Workmen engaged in construction work on a building were instructed to pick up and carry away all loose sheets of plywood. Two men picked up a loose sheet of plywood which, unknown to them, covered an opening in the floor of the building and when they moved forward to carry it away one of the workmen fell through the opening to the basement below and was injured. Neither of the workmen had been given any warning of the existence of the opening. The South Australian Supreme Court held that there was a breach of regulation 16(1).

In Phillips v. Robertson Thain Ltd. [1962] 1 All E.R. 527. It was concluded that all sides of a skylight had to be completed before it became an 'opening'. Builders who were constructing a roof left uncovered a 20 feet by 12 feet rectangular space which would ultimately form a skylight. The roof adjacent to 3 of the sides of this space had already been covered but the 4 th side was still open where a substantial area of roof had yet to be completed. On an information by the inspector alleging that the space was an 'accessible opening on a roof of a building' and charging the builders with failing to provide guardrails and toe-boards, or a covering for such an opening, Lord Parker, C.J. in the Queen.'s Bench Division held that the builders were not guilty of the offence charged because, although the fact that the whole roof had not been completed did not prevent the space being an 'opening in a roof', yet the space not being separated from the area unroofed had not yet become an 'opening in a roof'. But as soon as roofing is laid on all the sides a space for a well becomes an 'opening': Moorcroft $v$. Thomas Powles \& Sons Ltd. [1962] 3 All E.R. 741. A plasterer, while working on a flat roof, fell through a 5 feet by 3 feet well 
opening. It was held in the Queen's Bench Division that there was a breach of the regulations, and that either a covering or guardrails and toe-boards should have been provided. Similarly, in McArdle v. Andmac Roofing Co. and Others [1967] 1 All E.R. 583, the plaintiff who was working on a roof of a building stepped into an aperture and fell. The Court of Appeal held that the regulations were breached in that no covering, guardrails or toe-boards had been provided.

\subsection{Brittle Roofs: The New Zealand Construction Regulation} $34 \mathrm{~A}(1)$ requires that:

"No employer shall cause or permit any workman to walk over or work on, and no workman shall walk over or work on, any brittle roofing material unless there is affixed directly under the roofing adequate sarking, adequate metal mesh, or approved safety net."

The word 'permit' has been given a rather wide meaning by the courts and in Safety Inspector V. Fraei \& Edgar Ltd. (unreported 30.5.72), M. F. Hobbs, S.M. held that 'permitting' includes situations where the employer shuts his eyes to the obvious or allows something to go on not caring whether an offence is committed or not. Grays Haulage Co. Htd. V. Arnold [1966] 1 All E.R. 896 was applied. Similarly, the British 'brittle roofing' regulation was interpreted broadly in Donaghey v. Boulton \& Paul Ltd. [1967] 2 All E.R. 1014. The appellant, a steel erector, employed by sub-contractors to the respondents, was re-positioning asbestos sheets on the roof of a hanger when he lost his balance and fell through an open space in the roof. The House of Lords held that the respondents were in breach of the regulations as crawling boards were not used. The appellant was entitled to the benefit of the regulation since the mischief against which it was directed was the risk of an injury to a workman from a fall, and the fact that the accident had not happened in precisely the way contemplated by the regulation, as the fall had been through an open space and not through fragile roofing, was not material.

6.4 Fall of Objects: The New Zealand Construction Regulation 30 requires that: 
"Al1 reasonable precautions shall be taken to prevent tools, equipment, and materials used in construction work falling on to persons below and all such tools, equipment, and material shall, as far as practicable, be stored or placed as not to create a danger to workmen."

Britain has similar regulations, and in Bailey v. Ayr Engineering Co. Ltd. [1958] 2 All E.R. 222, the plaintiff was employed by electrical sub-contractors to fix wires inside an open brick shaft in a building which was under construction. Three employees of other sub-contractors accidentally lost control of some iron railing. The railing hit the top of the brick shaft and knocked loose a block of masonry which fell on the plaintiff. The Court of Appeal held that there was no breach of the regulations because the 'falling material or article' against which the regulation required a cover to be provided did not include material which had become part of the structure of the building. This case was lost on a legal technicality. But in the usual situation the regulations are held to be breached when objects fall and injure a workman. Both the main contractor and the sub-contractor were at fault in Upton v. Hipgrave Brothers [1965] 1 All E.R. 6. The plaintiff was injured when a wheel barrow full of bricks fell off an unguarded hoist on a building site. The hoist had been built by the main contractor and was also used by the sub-contractor. Marshall J. in the Queen's Bench Division held that both the main contractor and the sub-contractor were in breach of the regulations requiring that:

"... steps shall be taken to prevent any person who is working in that place from being struck by falling material or articles."

6.5 Access: The New Zealand Construction Regulation 32 (1) requires that:

"There shall be provided and maintained safe means of access to every place at which any workman has at any time to work, and provision shall be made for satisfactory egress."

If the means of access is a possible cause of injury to anybody acting in a way that a human being of the type who will use it may reasonably be expected to act in circumstances which may reasonably be expected to occur then it is not a 
'sufficient safe means of access': Trott V. W. E. Smith (Erectors) Ltd. [1957] 3 All E.R. 500. A steel erector while in the employment of the defendants had to traverse 10 feet along a girder 3 inches wide and 20 feet above the ground, without a handhold. He fell from the girder and was killed. It would have been reasonably practicable to have provided a safer means of access by laying planks across the girders but planks were not ordinarily used to provide access in operations of the character of this erection. The Court of Appeal held that the regulation was breached. But in Woods V. Power Gas Corporation (1969) 8 K.I.R. 834 it was held that there was no breach when a steel erector fell 20 feet. The plaintiff had been sitting astride a steel girder and the Court of Appeal concluded that the danger contemplated involved consideration of the likelihood and not the possibility of its occurring, and since on the evidence sitting astride a girder was a familiar working position for a skilled steel erector, it could not be said that the plaintiff's loss of balance in that position was likely to occur.

The 'access' regulations may be breached by such minor details as not providing handles for doors, or obstacles on pathways. In Jennings v. Norman Collison (Contractors) Ltd. [1970] 1 All E.R. 1121, the plaintiff fell from a passageway on a roof while he was shutting a door with a key, there being no handle. The test in Trott was applied and the Court of Appeal held that the means of access was unsafe. The obstruction in Smith V. Vange Scaffolding and Engineering Co. Ltd. and another [1970] 1 All E.R. 249 was a cable placed across a path by a welder employed by the main contractor. The plaintiff who was employed by the first defendant (a subcontractor to the second defendant, the main contractor) tripped over the cable while going to the changing hut at the end of the day. It was held that there was a breach of the access regulation. In Singh v. Vange Scaffolding and Engineering Co. Ltd. (1969) ? K.I.R. 101 , the plaintiff, a scaffolder, while carrying a scaffold pole caught his heel in a hole and injured his back, and it was held that there was a breach of the access regulation. However loose rubble 
on a path may not cause a breach: Smith V. George Wimpey \& Co. Ltd. and another [1972] 2 All E.R. 723. The plaintiff, an employee of the first defendant, who was a sub-contractor to the second defendant, was injured when he tripped over rubble on a path while engaged on bridge construction work. The Court of Appeal held that there was no breach of the access regulation. Lord Denning M.R. stated at page 727 that:

"... the mere presence of loose rubble on it (the path) does not make it unsafe. No contractor could be expected to have a man brushing away loose rubble all the time. This was a building site on which rubble must be expected anywhere."

Access that is satisfactory in dry weather may become unsafe in bad weather: Byrne v. E. H. Smith (Roofing) Ltd. [1973] 1 All E.R. 490. The plaintiff, while assisting in cleaning out gutters on the roof of a building after a heavy rain storm, fell through asbestos sheeting and was injured. The defendants were held, by the Court of Appeal, to be in breach of the access regulation as the weather conditions prevailing at the time of the accident were reasonably foreseeable by the defendants and a means of access which was safe in those conditions had not been provided.

In the case of Australian Paper Manufacturers Ltd.v. Conyers [1962] N.S.W.R. 449, the New South Wales Supreme Court held that for proving an unsafe access it was not necessary to prove that no other safe route existed.

\subsection{Excavations: The New Zealand Construction Regulation 71} requires that:

"Every face more than $1.5 \mathrm{~m}$ high of any excavation shall be timbered unless -

(a) The face is cut back to a safe slope; or

(b) The material in the face is of proven good standing quality under all anticipated conditions of work and weather; or

(c) The provision of timbering is impracticable or unreasonable by reason of the nature of the work and other adequate safety precautions are taken to the satisfaction. of the Inspector; or

(d) By reason of the nature of the work and the position of workmen carrying out work in. the vicinity, there is no danger to those workmen." 
This regulation was interpreted in Safety Inspector $\mathrm{v}$. Russe11_Pemberton Ltd. (1979) 14 MCD 344. A $2.4 \mathrm{~m}$ deep 'untimbered' trench collapsed injuring a workman employed by the defendant. The defendant claimed an exemption under proviso (b) that the material in the face was of 'proven. good standing quality' in that 500m of trench had been excavated without any indication of a collapse. T. B. Mooney, S.M. held that pursuant to section $27(1)$ (d) of the Construction Act 1959 the obligation to timber the trench was absolute unless the defendant could bring itself within one of the four provisos to regulation 71. The Magistrate referred to the "Code of Practice for Excavation" issued by the Chief Safety Engineer and said at p.345:

"All defence witnesses agree that this particular code forms the prescribed study for the issue of a Safety Supervisor's Certificate and all three have that qualification. On p.26 of the code it is said that ground encountered in trench excavations can be one of the following three main kinds:

(a) Hard compact soil;

(b) Soil liable to crack or crumble;

(c) Loose or running material.

I have been told that this ground fell closest to the first of these three grades. It was of sand with clay binding. The code goes on to say 'of these materials (a) is the type which can cause the most trouble because the face looks good and this often leads to risks being taken'."

Mr. Mooney went on to hold that it is the 'material' in the face that must be proven good standing quality rather than the face itself, and that in this case this particular material had been proven to be of other than good standing quality and the obligation of the defendant was to timber throughout.

If an excavation or trench varies in depth the court may look at the work 'as a whole' in interpreting the regulations: Zajackowski v. Snowy Mountains Hydro-Electric Authority (1968) 1. N.S.W.R. 710. Jacobs, J.A. for the New South Wales Court of Appeal held that the definition of 'excavation work' in section 3 of the Scaffolding and Lifts Act, 1912 (N.S.W.) must be read so that in any particular case the work as a whole is looked at and if as a whole the excavation is 5 feet deep or more any particular part of it which is less than 5 feet deep nevertheless falls within the definition. The 
New Zealand Construction Act 1959 and regulations contain similar provisions.

6.7 Mechanical Plant and Machinery: Under the Construction Act 1959 a road tractor was defined as 'plant' in Safety Inspector v. Allan Gordon Hall (unreported 23.11.77). The defendant was charged under section 15 with failing to maintain plant in good order. A defective tractor had been used for mowing road verges and an accident had resulted. W. M. Willis, S.M. held that under section 2 'mechanical plant' did not include a 'tractor'. A 'tractor' was defined a 'plant' in section 15. In Kirkpatrick $v$. Lewis Construction Pty. Ltd. [1964] V.R. 515, it was concluded that when a crane was being erected it was not being 'used'. The plaintiff's husband was killed when the jib of a tower crane which was being hoisted into position for installation fell on him. Section 11(3) of the Victorian Lifts and Cranes Act 1959 provided that no proprietor of a crane:

"... shall use the crane or permit or cause the crane to be used unless it is in an efficient state and is safe to operate."

The Supreme Court of Victoria held that at the time of the accident the crane was not being 'used' within the meaning of the section.

An electric hand tool may be defined as 'machinery':

Loverlidge v. Anselm olding and Sons Ltd. [1967] 1 Al1 E.R. 459. The plaintiff, a mason, was employed by the defendant and was injured while cutting slots in a granite block. He was using an electric cutting wheel hand-tool and his tie became entangled with the exposed part of the shaft and the tool struck him, fracturing his jaw. Widgery, J. in the Queen's Bench Division held that there was a breach of Regulation 42 of the Construction (General Provisions) Regulations 1961 , requiring dangerous parts of machinery to be securely fenced. The dictionary definition of 'machinery' was used, i.e. apparatus for applying mechanical power consisting of a number of parts each having separate functions.

6.8 Demolition: The New Zealand Construction Regulation 126(1) requires that:

"Before demolition is commenced, and also during the progress of the work, reasonable precautions shall be 
taken to prevent the accidental collapse of any part of the building or structure or retaining wall, or of any adjoining building or structure or retaining wall the collapse of which may endanger any property."

Regulation $126(2)$ requires that:

"Building materials shall not be cut or released if there is a likelihood of injury to persons or damage to property arising from any twisting, springing, or collapse thereof."

The British regulations also require that collapse must be prevented when carrying out demolition work. In Knight $v$. Demolition \& Construction Co._[1953] 2 All E.R. 508, two workmen, who were demolishing disused gas retort blocks, were killed while working under a wall of a brick arch which collapsed on them. The wall was not propped or shored in any way, and the defendants were held, by Parker. J., to be in breach of the regulations in that they should have appreciated the danger of sending workmen to work under the wall without any precautions having been taken. However, the breaking of a floor board may not be a 'collapse' under the regulations: Mortimer v. Samuel B. Allison Ltd. [1959] 1 Al1 E.R. 567. The appellant was employed by the defendant on demolition work. In the first floor of the building being demolished a large hole had been made through which debris was dropped from a higher floor into a truck standing beneath the hole. Over a period of time the edges of the hole had been repeatedly struck by pieces of rubble and debris which had been thrown down and had missed the hole. Debris thus collected on the floor and from time to time had to be cleared by a workman who lifted it and threw it through the hole. The appellant had just completed such a clearance when a floor board broke or moved beneath his feet and he fell through the hole sustaining serious injuries. The House of Lords held that the regulations had not been breached. The breaking off of part of a floor board was not a 'collapse' of a part of the building nor was it necessary to support the floor to prevent accidental collapse of any part of the building. Viscount Kilmuir, L.C. at page 570 said that 'collapse' in the regulations means the action of falling together, or a sudden shrinking together, or a giving-away through external pressure, or loss of rigidity, or loss of support. 
The Court of Appeal in Boyton v. Willment Brothers Ltd. [1971] 3 All E.R. 624, concluded that for demolition all the requirements for 'construction work' should be met, and in particular, passageways should be provided with guardrails. The plaintiff was employed by the defendants who were demolishing a warehouse. Passageways about 4 feet wide were left intact on the floors to enable the men to carry out their work. The plaintiff fell from a passageway, and it was held that the defendants were in breach of the regulations in not providing guardrails as it is not impracticable to provide such safeguards for demolition work.

6.9 Eye Protection: The New Zealand Construction Regulation 33(1) requires that:

"Where any operation involves a special risk of injury to the eyes of any workman, the employer shall provide suitable goggles which shall be used by workmen during the operation."

It was held that goggles were required for cutting earthenware pipes in Littler v. G. L. Moore Ltd. [1967] 3 All E.R. 801. The plaintiff, who was employed by the defendant, was cutting glazed earthenware pipe with a metal hammer and tiling chisel when a fragment of metal flew off and lodged in his eye. Brabin J. held that the defendant was in breach of the regulations in not supplying goggles or screens to protect the plaintiff's eyes. The Court of Appeal in Hobbs v. C. G. Roberertson Ltd. [1970] 2 All E.R. 347 did not have to decide exactly the same question and was not prepared to affirm or overrule Littler. In Hobbs the plaintiff was employed by the defendant to remove a chimney in a house. Some brick lodged in the plaintiff's eye and subsequently the eye had to be removed. It was held that Regulation 52 of the Construction (General Provisions) Regulations 1961 requiring goggles for '... breaking, cutting, dressing or carving stone, concrete, slag or similar materials by means of a hand tool', did not apply to 'brick' which was not 'similar materials', it being unthinkable that the commonest building materials should not have been specifically named if it was intended to include it. Similarly, in Baker v. F. Rendell \& Sons Ltd. [1970] 3 All E.R. 442 , it was concluded that goggles were not required for nailing work. A piece of metal fragmented from the plaintiff's hammer and lodged in his eye while he was nailing a wooden battern 
to some concrete. Lloyd-Jones, J. held that nailing was not a 'process' within Regulation 52 and that the batten itself provided a screen.

6.10 Asbestos Dust: The New Zealand Asbestos Regulations 1978, made under the Construction Act 1959, the Factories Act 1946, the Shops and Offices Act 1955 and the Health Act 1956, came into force on the 1st day of May 1979. In Atkinson $v$. Sir Alfred McAlpine \& Son Ltd. (1974) 16 K.I.R. 220, a case under the British Asbestos Regulations, 1969, it was held that the obligations imposed on the employers were 'absolute'. The defendants were demolishing a brewery and employed workmen to remove lagging from steel beams. The lagging contained $40 \%$ crocidolite (blue asbestos). The defendants and the workmen did not know or have reason to suspect that the process involved asbestos. They could not have ascertained it by inspection and could have known only by taking a sample and having it analysed. The defendants were charged with offences of breaching the requirements in the regulations of giving 28 day's advance notice in writing before beginning to undertake the process, and not having provided approved respiratory protective equipment and protective clothing for each workman. The magistrate was of the opinion that it was a defence for the defendants to prove, as they had, that they were not conscious of the facts which constituted the of fence and that they had no reasonable grounds for supposing that such facts existed, and he dismissed the informations. The appeal by the prosecutor was allowed and it was held that the obligations imposed by the regulations were absolute.

\subsection{Work in Compressed Air: In New Zealand, work in} compressed air is regulated by a code of practice (see para.4.5). The only case reported under similar British regulations is that of Ransom \& Daniels v. Sir Robert McAlpine \& Sons Ltd. (1971) 15 K.I.R. 141. The plaintiff's were employed as labourers by the defendants on the construction of a tunnel below sea-level. The work involved the use of compressed air and necessitated the plaintiffs working in conditions to which the Compressed Air Regulations, 1958 applied. When entering or leaving work in the tunnel the plaintiffs under-went the procedures of compression or decompression in a man-lock. 
The plaintiffs contracted caisson disease in the form of necrosis of the bones. It was held that the defendants were in breach of the regulations in that the decompression procedures were not carried out in accordance with the statutory tables, that the door of the man-lock leaked and was ill-fitting, that there was overcrowding inside the manlock, and that the man-lock attendants were inadequately trained.

6.12 Health and Welfare: Depending on the nature of the work inspectors must use their discretion in administering the health and welfare requirements in Part IV of the Construction Regulations 1961 (see para.3.3). However, reasonable facilities must be provided for workmen. In Safety Inspector v. V. A. Draper \& Co. Ltd. (unreported 25.2.66), charges were laid under Regulation 21 for failure to provide first aid facilities, Regulation 23 for failure to provide adequate toilet facilities, and Regulation 24 for failure to provide adequate meal accommodation. J. F. Keane, S.M. held that 'to provide' the facilities they must be placed:

"... where they come easily and obviously to the workman, or at the very least, that he should be given clear directions where he is to get them." (Inspector of Factories v. Maoriland Timber Co. [1965] N.Z.L.R. 613.) 

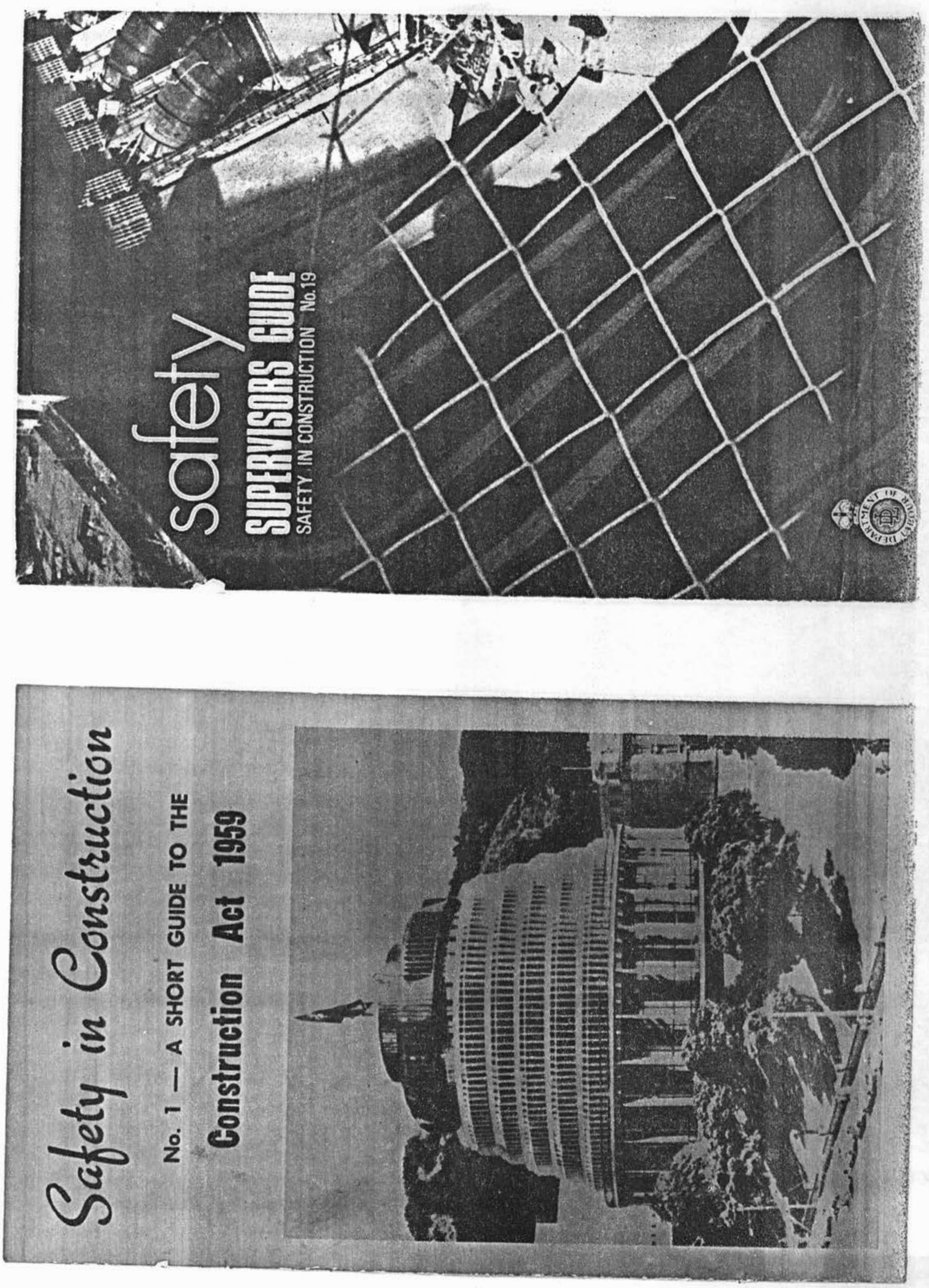


\section{PART III}

OVERSEAS LAW

This Part examines the legislation in Britain, Australia and Canada and highlights the more important provisions and developments. In Australia and Canada, safety, health and welfare law is the responsibility of each of the States and Provinces. Thus there are some 18 separate jurisdictions to be studied, and they are more noticeable by their differences than by their uniformity. However, there is a definite trend towards one statute covering all workplaces, with separate regulations and codes for each industry. As will be seen from the outline in the following chapters consolidation has now been achieved in Britain, South Australia, Tasmania and al1 the Canadian Provinces except for Nova Scotia. These enactments, and the regulatory framework of each, should be closely studied when reviewing the New Zealand law. The two Acts most appropriate for New Zealand industry and which come closest to meeting the conceptual criteria set out under para.4.8 (Reform) are the Tasmanian Industrial Safety, Health and Welfare Act 1977, and the Ontario Occupational Health and Safety Act 1978, and these have been included as Appendix $D$ and $E$.

\section{Britain}

\subsection{The Health and Safety at Work etc. Act 1974: This Act,} which was based on the Robens Report, (Safety and Health at Work, H.M.S.O. Cmnd. 5034, 1972) is primarily an enabling: measure, the main strength of which is that it provides powers to devise new controls for new industrial safety problems as they occur. The statute is designed to create a more unified and integrated system, with the aim of increasing the effectiveness of the State's contribution, and it applies to almost all places of work, and thus it implements the Robens recommendation of creating a single consolidating measure.

Section 1 of the Act is a policy statement and sets out the general purposes of the first part of the Act as securing the health, safety and welfare of persons at work, and the 
protection of persons, other than persons at work, against risks to health or safety arising out of or in connection with the activities of persons at work. The definition of 'work' makes it clear that the Act applies to all employees and selfemployed persons except domestic servants. The Act aims at progressively replacing the existing statutes and regulations by a new system of regulations and approved codes of practice designed to improve the standards established by that legislation, including the Factories Act 1961, the Mines and Quarries Act 1954, the Agriculture (Safety, Health and Welfare Provisions) Act 1956, and the Offices, Shops and Railway Premises Act 1963.

Another recommendation of the Robens Report, which is contained in the Act, is the creation of conditions for more effective self-regulation. Sections 2 and 3 sets out the duties of employers, employees, and the self-employed to others, and in broad terms is a restatement of the common law. Sections 4 and 5 set out the duty of persons in control of premises, section 6 states the general duty of those who design, manufacture, import or supply any article for use at work, and section ? states the general duties of employers. Employers, in prescribed circumstances, are required to make written statements of policy for safety and health available to their employees under section 2 , and section 3 contains similar provisions for those members of the public whose health and safety may be affected by industrial processes. Section 2 also allows trade unions to appoint safety representatives who must be consulted by the employer, and provides for the establishment of safety committees.

Section 10 establishes the Health and Safety Commission, and its executive arm, the Health and Safety Executive under the control of the secretary of state. It is the secretary of State who has the principal responsibility for the administration of the Act, and for the appointment of members of the Health and Safety Commission, and approves the appointment of the members of the Health and Safety Executive.

The Commission is enabled, under section 14 , to hold inquiries, to carry out investigations and to issue codes of practice, which although not binding as regulations, nevertheless provide relevant evidence in criminal proceedings 
(sections 16 and 17). The Health and Safety Executive has the responsibility of enforcing the Act but it may delegate to local authorities under specified conditions (section 18). However, section 45 provides for retransfer of enforcement powers from a local authority to the Executive where the authority is found wanting. The factory and other inspectors were brought together under the control of the Executive which has the authority to appoint new inspectors (section 19). Under sections 21 to 23 inspectors have new powers to issue improvement and prohibition notices, and under section 24 , appeals against such notices are to an industrial tribunal.

Sections 33 to 42 set out the provisions in respect of offences and provides that it is an offence for any person to contravene specified provisions. Certain offences are punishable on summary conviction with a maximum fine of $\$ 400$, and other offences are punishable on summary conviction with the same fine, or on conviction on indictment, either by imprisonment for a maximum term of 2 years, or a fine, or both, and for $£ 50$ a day for a continuing offence. Proceedings for an offence may not be instituted except by an inspector, or by or with consent of the Director of Public Prosecutions.

In any proceedings for failure to comply with a duty or requirement to do something, so far as is practicable, or so far as is reasonably practicable, or to use the best practicable means to do something, the defendant has the onus of proof. Where the offence is due to the act or default of some other person, that other person can be held liable for the offence, and a person may be charged with, and convicted of the offence, whether or not proceedings are taken against the person with statutory responsibility. If an offence is committed by a body corporate, and is proved to have been committed with the consent or connivance of, or to have been attributable to any neglect on the part of, any director, manager, secretary, or other similar officer, he as well as the body corporate is guilty of the offence.

7.2 The Existing Factory Legislation: The Factories Act 1961 , is itself, a consolidating measure and supercedes the earlier statutes (see Part 1). The Act covers 'building operations' 
and 'works of engineering construction' and the detailed provisions are contained in the Construction (General Provisions) Regulations, 1961, S.I. No. 1580; the Construction (Lifting Operations) Regulations, 1961, S.I. No. 1581; the Construction (Working Places) Regulations, 1966, S.I. No. 94; and the Construction (Health \& Welfare) Regulations, 1966, S.I. 95.

7.3 The Construction (General Provisions) Regulations 1961: These regulations apply to excavations (including shafts and tunnels), cofferdams, caissons, explosives, demolition, dangerous atmospheres, work on, or adjacent to water, transport and other miscellaneous subjects.

Every contractor and every workman has a duty to comply with the regulations, and it is the duty of every person employed to comply with the requirements that relate to the performance of, or the refraining from an act by him, and to co-operate in carrying out the regulations, and if he sees any breach or defect in the plant or equipment he must report it to his employer, foreman, or safety supervisor. Where twenty or more persons are normally employed a contractor or employer must appoint a safety supervisor to advise him as to the observance of the statutory safety requirements, to exercise general supervision over the employees and to promote the safe conduct of work.

\subsection{The Construction (Lifting Operations) Regulations 1961:}

Every contractor and employer of workmen is required to comply with these regulations which relate to lifting appliances, hoistways, raising and lowering persons, and the securing of loads. Each employee must also comply with the regulations which relate to him, and if he discovers any breach in the plant or equipment, he is required to report it to the employer or foreman.

7.5 The Construction (Working Places) Regulations 1966: These regulations relate to scaffolding and other places of work and the responsibilities of contractors, employers and employees are the same as for the above two sets of regulations. There must be suitable and sufficient safe access to, and egress from, every place at which any person, at any time, works and so 
far as is reasonably practicable every place at which a person works must be made and kept safe. Where work cannot safely be done on or from the ground, or from part of a building, or other permanent structure, scaffolds must be provided, or where appropriate, ladders, or other means of support. Scaffolds must be erected, altered, or dismantled under the immediate supervision of a competent person, and so far as possible by competent and experienced workmen, and scaffolding material must be inspected by a competent person on each occasion before use.

7.6 The Construction (Health \& Welfare) Regulations 1966:

Every contractor must provide first aid facilities, accommodation, protective clothing and equipment, washing and drinking water, and sanitary conveniences. The detailed requirements vary depending on the number of employees and the nature and location of the work. 


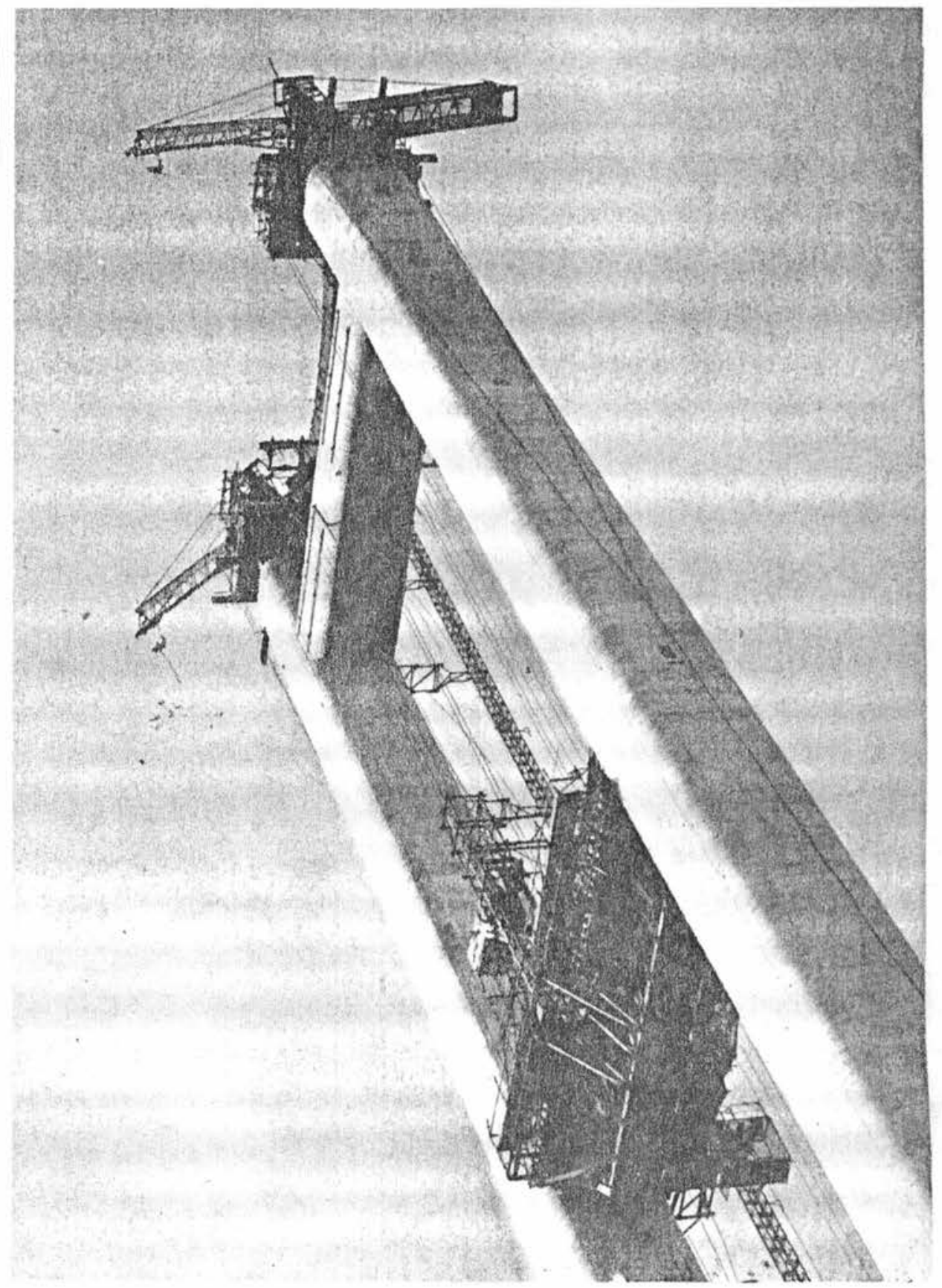

North Bank tower of the Humber Bridge 


\section{Australia}

\subsection{Western Australia}

The Department of Labour and Industry is responsible for administering 30 different statutes, including the Construction Safety Act, 1972, the Factories and Shops Act, 1963, and the Inspection of Machinery Act, 1921.

The Inspection and Technical Services Division of the Department is controlled by a professional engineer who reports to the Secretary for Labour. The Division has four Branches, each controlled by a Deputy Chief Inspector: Construction, Machinery, Factories and Shops and Weights and Measures. 8.1.1 The Construction Safety Act, 1972: The Act is administered by the Minister, and subject to any direction of the Minister, by the person holding the office of Secretary for Labour in the Department of Labour in the Public Service of the State (s.8).

Inspectors of construction safety are appointed as the Minister considers necessary, including a Chief Inspector, and a Deputy (s.9). The principal functions of inspectors are to promote the safety and welfare of workmen, to advise employers and workmen as to safe practices, to ensure that the Act is complied with, to investigate accidents, and to prevent accidents (s.10). (This section is identical to s.6 of the New Zealand Construction. Act 1959). Dangerous works, as prescribed by the Governor, must be notified to the Chief Inspector (s.16).

The Minister may, for the purposes of hearing appeals under the Act, constitute Boards of Reference, or an arbitrator. A Board of Reference consists of three members appointed by the Minister, of whom, one is appointed on the written nomination of the employers carrying out the work, and one on the written nomination of the workers engaged on the particular work. Two members form a quorum and the decision. of any two members is the decision of the Board. An appeal lies on a question of law to the Magistrate of the Local Court at Perth (s.17).

The Act provides for a Construction. Safety Advisory Board consisting of a Chairman and two other members appointed 
by the Governor. The Chairman is the Secretary for Labour, and one is appointed upon the joint written nomination of the Western Australian Employers' Federation, The West Australian Chamber of Manufacturers, Master Builders Association of W.A., and the W.A. Branch of the Australian Federation of Construction Contractors, to represent employers. The other member is appointed upon the written nomination of The Trades and Labor Council of Western Australia to represent the employees. The Board is required to investigate and make recommendations to the Minister with regard to all measures necessary for securing the safety and welfare of employees, including the prevention and diminution of noise, the lighting and ventilation of sites, the prevention of accidents, the supply and use of protective clothing and protective equipment, the welfare of employees, the provision of facilities for taking meals, for medical and first aid attention, the making, amending or revoking of any regulation, and for any matter that may be prescribed (s.20).

Every main contractor must ensure that the requirements of the Act are complied with, and every subcontractor must ensure that the Act is complied with on the part of the site where work is being carried out by him (s.23). Every employer is required to provide protective equipment and every workman must wear or use such equipment (s.24). An owner, main contractor, or subcontractor may request an inspector, in writing, to issue to him an inspection report after a site has been inspected (s.33).

8.1.2 Offences and Penalties: Where a person is charged with an offence he is entitled to have any other person whom he alleges to be the actual offender charged (s.42). (This is similar to s.25 of the New Zealand Construction Act 1959.) Proceedings are determined by a Court of Petty Sessions constituted by a Stipendary Magistrate sitting alone (s.43). Section 44 is the offence creating provision and states that a person. who contravenes any provision, or does not do that which, by or under the Act, he is required or directed to do, 
commits an offence and is liable to a fine of $\$ 400$ and $\$ 20$ per day for a continuing offence. Where a body corporate is convicted of an offence every director or member of the governing authority of the body corporate who authorised, directed, or consented to the contravention or failure is deemed, without affecting the conviction against the body corporate, to be guilty of an offence. Section 45 states that no prosecution for an offence shall be instituted without the consent in writing of the Chief Inspector.

Approximately 40 prosecutions are instituted each year, and the general range of penalty on conviction varies between $\$ 5$ and $\$ 200$ for each offence.

8.1.3 The Construction Safety Regulations, 1973: The

Regulations are divided into 13 Parts and provide detailed requirements for: Notifiable work and Fees for service, Construction of Scaffolding, Hoisting Appliances, General Safety, Roofs sheathed with Brittle Roof Materials, Explosive Powered Tools, Use, Storage and Conveyance of Explosives on a Site, Compressed Air and Diving Work, Examination for Certificates, Licences and Permits.

(In particular the regulations for Protective Equipment, Formwork and Falsework, and Brittle Roofing should be studied when updating the New Zealand regulations.)

\subsection{South Australia}

The Department of Labour and Industry is responsible for the administration of 18 statutes including the one 'omnibus' Industrial Safety, Health and Welfare Act 1972 which came into force on the 1st of April, 1974.

\subsubsection{The Industrial Safety, Health and Welfare Act, 1972:} The Act applies to all industries except any mine under the Mines and Works Inspection Act 1920 and any work under the Petroleum (Submerged Lands) Act 1967.

An "Industrial Safety, Health and Welfare Board" is established to make recommendations to the Minister. The Board comprises four representatives of the United Trades and Labor Council of S.A., one representative each from the Chamber of Commerce and Industry S.A., the Master Builders' 
Association of S.A., and the S.A. Employers' Federation, a representative of the Metal Industries Association of S.A., the Chief Inspector of Industrial Safety, and the Permanent Head of the Department (Chairman) (s.8 to s.16). The Governor appoints the inspectors including the Chief Inspector (ss.17 \& 18).

The 'constructor' is required to give notice of any 'construction work' to the Permanent Head and to pay a prescribed fee (s.26). The fees are in proportion to the cost of the project.

Every employer in any industry, every occupier of industrial premises and every constructor in relation to any construction work must ensure that the provisions of the Act are complied with and must take all reasonable precautions to ensure the health and safety of workers (s.29). A worker must not by any act or omission render less effective any action taken by a person for the purposes of giving effect to section 29 (s.30).

Where the Chief Inspector is satisfied that compliance with the provisions of any regulation may not in all the circumstances be reasonably practicable, and a modification or variation of the provisions would not adversely affect the safety, health or welfare of the workers concerned, he may by notice in writing to the constructor modify or vary the provisions of the regulations (s.38).

In 1978. 71 prosecutions were taken under the Act, and 51 convictions were entered. Penalties imposed under Part IV of the Act and regulation 221 ranged between $\$ 5$ and $\$ 350$, and averaged $\$ 300$.

8.2.2 Construction Safety Regulations 1974: These Regulations are divided into 11 Parts and include detailed requirements for: Scaffolding and Gear, Demolition of Buildings and Structures, Excavation. Work, Compressed Air Work, Electrical Equipment, Explosives, Explosive Powered Tools, Power Driven Plant and Equipment, Hoisting Appliances, Protective Equipment, Amenities, Safety Supervisors and Workers' Safety Representatives and Riggers. The First Schedule sets out the fees to be paid in respect to all construction work. (In 
particular, the Scaffolding and Demolition provisions should be studied when revising the New Zealand Regulations.)

\subsection{Victoria}

The Department of Labour and Industry is responsible for the administration of 9 statutes, including the Boilers and Pressure Vessels Act 1970, the Industrial Safety Advisory Council Act 1960, the Labour and Industry Act 1958, the Lifts and Cranes Act 1967 and the Scaffolding Act 1971. The Division of Inspection Services under the direction of the Chief Inspector of Factories and Shops controls the Labour and Industry Act 1958, and the other Safety Acts are controlled by the Division of Technical Services with a Chief Engineer as Divisional Head.

8.3.1 The Scaffolding Act 1971: A supervisor of Scaffolding Inspection is appointed under the Public Service Act 1958 and he is required to report to the Secretary of Labour and Industry as to the manner in which the functions of inspectors are carried out in the municipal districts (s.5). Each municipal council is directed and authorized to exercise and perform (within its municipal district) all powers and duties under the Act and is required to appoint inspectors and officers as are necessary (s.6).

The contractor for the erection, demolition, alteration, repair, or any other kind of work in connection with any building, structure, ship, or boat, must ensure that scaffolding and hoists are erected for the use of any person engaged on any such work which cannot be done safely from the ground, or from solid construction, and the employer of such person must ensure that the scaffolding is maintained in an efficient state, and that his employee uses the scaffolding (s.9).

The Governor in Council is required to appoint three persons to be a Board of Examiners to examine persons who desire to qualify as inspectors and as scaffolders (s.15), and only certificated scaffolders can erect, alter or dismantle scaffolding (s.16).

The Governor in Council is also required to appoint a Scaffolding Regulations Committee of 8 members comprising a qualified engineer or architect, the Supervisor of Scaffolding Inspection, an inspector appointed under the Lifts and Cranes Act 1967 , a member of the Building Regulations Committee, one 
from a panel of three names submitted by the Master Builders Association of Victoria, the Victorian Trades Hall Council, and the Australian Institute of Building Surveyors. The functions of the committee are to prepare and submit to the Minister draft regulations and to enquire into and report to the Minister upon any matter relating to methods and materials used in the erection of scaffolding ( $s .18$ ).

Since the introduction of the Scaffolding Act 1971 , only 5 prosecutions have been taken, and a $\$ 20$ fine was imposed for each offence.

A Construction Safety Bill is currently being considered by the Victorian Parliament. This Bill is aimed at consolidating the law relating to safety in the building and construction industries now contained in the Scaffolding Act 1971, and the Labour and Industry Act 1958, and at adding broad regulation-making powers over the safety aspects of Building and construction work.

8.3.2 The Scaffolding Regulations 1974: These Regulations will be repealed and replaced with construction safety regulations covering the construction industry once the Construction Safety Bill is passed. The present scaffolding regulations provide an excellent code for scaffolding and ladders.

\subsection{Tasmania}

The Department of Labour and Industry administers? statutes, including the Industrial Relations Act 1975, The Workers Compensation Act 1927, and The Industrial Safety, Health and Welfare Act 1977, Machinery Act 1960, and the Factories, Shops, and Offices Act 1965.

8.4.1 The Industrial Safety, Health, and Welfare Act 1927:

This Act became operative on January 1, 1979, and it provides for persons employed, engaged in, or affected by industry, and for the safety of persons using amusement devices and public stands.

The Governor may appoint persons to be the Secretary for Labour, the Assistant Secretary for Labour, and such other officers as he thinks necessary for the administration of the Act (s.9). 
An Industrial Safety, Health and Welfare Board is established, consisting of five members appointed by the Governor: the Secretary for Labour (Chairman), the Director of Public Health, the Director of Mines, a representative of the occupiers of work places, and a representative of the employees in work places. The Board investigates and makes recommendations to the Minister with respect to measures necessary for securing the safety, health and welfare of employees, it collaborates with organisations of employers and employees, and with authorities engaged in technical research (s.18).

A person. who intends to undertake construction work must notify the Secretary for Labour and pay the prescribed fee (s.29).

Every occupier of a work place and every person carrying on an industry must take reasonable precautions to ensure the health and safety of persons employed or engaged at that work place or in that industry (s.32). No employee shall by any act or omission render less effective any action taken by a person for the purposes of giving effect to section 32 .

It is considered that this Act achieves most of the conceptual requirements formulated in para.4.8, and it is the most relevant of the Australian statutes for consideration. when the New Zealand legislation is being consolidated. The Tasmanian Act is reproduced as Appendix D.

New regulations under the new Act will be effected in 5 separate groupings: (1) Administrative and General, (2) Construction Safety, (3) Pressure Vessels, (4) Lifting Machinery, and (5) Rural and Forest Industries.

The Industrial Safety, Health and Welfare (Administrative and General) Regulations, 1979 became operative on the 2 nd of May, 1979 and relate to physical working conditions. The administrative component simply deals with registration, accident reporting and appeal provisions.

The Construction Safety Regulations will be based on uniform standards currently being developed by a working party of officers from the state Departments of Labour. In the meantime the Scaffolding Regulations 1963 provide a comprehensive code for all types of scaffolding and for ladders. 


\subsection{Queensland}

The Construction Safety Act 1971 is administered by the Construction Safety Branch of the Department of Labour Relations. The Branch consists of a Chief Inspector, a deputy, a senior inspector, 2 assistant senior inspectors, 12 inspectors, and 5 cadets in Brisbane, and 14 inspectors stationed in country areas. Within the head office there is a special section which looks after the checking of designs which are submitted for approval and arranges for investigations and tests. The cadets enter the Division at Matriculation level and before qualifying as inspectors are required to complete the Degree in Building. During the course, which takes 5 to 6 years, the cadets are given extensive internal training within the Branch. It is proposed that all staff will be recruited in this manner in future years.

8.5.1 The Construction Safety Act 1971: The Act is designed to provide for the safety and welfare of persons engaged in construction, and other associated work, and for members of the public, in respect of danger from such work.

The statute is administered by the Minister and, subject to him, by the Chief Inspector, the inspectors and other officers appointed for the purposes of the Act (s.7). The Governor in Council is required to nominate the places throughout Queensland as centres for the location of inspectors (s.10).

The functions of inspectors are to promote safety, to advise and recommend to employers and workmen safe practices, to prevent accidents, to promote the safety of the public on any site, and to investigate accidents.

A 'constructor' is required to ensure that the Act is complied with on the whole project, and the 'subcontractor' has this responsibility for the particular part of the work on which he is engaged. The 'employer' is also required to ensure the safety of his workmen on the site, and 'workmen' have a duty not to endanger themselves or any other person (ss.20 to 23).

The Governor in Council is required to prescribe dangerous work as 'notifiable work' and the constructor and each subcontractor must notify the Chief Inspector 24 hours before commencing the work (ss.38 \& 39). Certificates of competency are required for all scaffolders, riggers, hoist drivers, dogmen, and explosive powered tool operators (ss.51 to 57). 
The 'constructor' is required to appoint a 'Project Safety Officer' on specified projects where 30 or more persons are engaged, and that officer is responsible to the

'constructor' for overall safety on the site (s.58). On these projects the workmen engaged on the site may together elect a 'safety representative' who is entitled to make a weekly inspection of the site and report to the Project Safety Officer (ss.59 to 61).

8.5.2 Offences and Penalty: A person who contravenes the Act commits an offence and is liable to a maximum penalty of $\$ 5,000$ where, as a consequence of the contravention, or failure to comply, loss of life of any person, or serious bodily injury to any person, has occurred (s.69). A prosecution for an offence is conducted by way of summary proceedings before an industrial magistrate and there is a right of appeal to the Industrial Court. Proceedings are commenced by complaint of the Chief Inspector (s.70). When convicting any person. of an offence that is committed in respect of construction. equipment the industrial magistrate may make an order that the equipment be forfeited to the Crown (s.72).

The constructor, subcontractor or employer, who is in control of the work is deemed to have committed the offence, and is liable, except where it appears from the Act that another person was intended to be solely liable for the offence, or where he did not know, and could not by the exercise of reasonable diligence have known, of the commission of the offence $(s .74)$.

8.5.3 Construction Safety Regulations 1972: These regulations came into force on the 2nd of April, 1979, and they provide a comprehensive code of requirements. They are divided into 18 Parts including: Notifiable work, Construction Work, Construction Equipment, Prevention of Fires, Electrical Hazards and Lighting, Protective Clothing and Equipment, ExplosivePowered Tools, Qualifications for Inspectors, Certificates of Competency and Permits, Project Safety Officers, Safety Representatives, Safety Committees, Appeal Procedure, Fees, and Signs.

\subsection{New_South Wales}

The Department of Labour and Industry administers 21 statutes, including the Dangerous Goods Act, 1975, the Explosives Act, 1905, the Factories, Shops and Industries Act, 
1962, the Industrial Arbitration Act, 1940, the Inflammable Liquid Act, 1915, and the Construction Safety Act, 1912. These Acts are controlled by a professional engineer with the designation of 'Director and Chief Inspector' of the Division. of Inspection Services.

8.6.1 Construction Safety Act, 1912: This Act, prior to 1978 , was named the Scaffolding and Lifts Act, 1912, and it is being subjected to an extensive review this year. A completely revised Act and new Construction Safety Regulations which will replace the Scaffolding and Lifts Regulations should be available early in 1980. It is, therefore, inappropriate to comment on the existing provisions, which although presenting excellent technical detail, are outdated in their administration and procedural framework. 


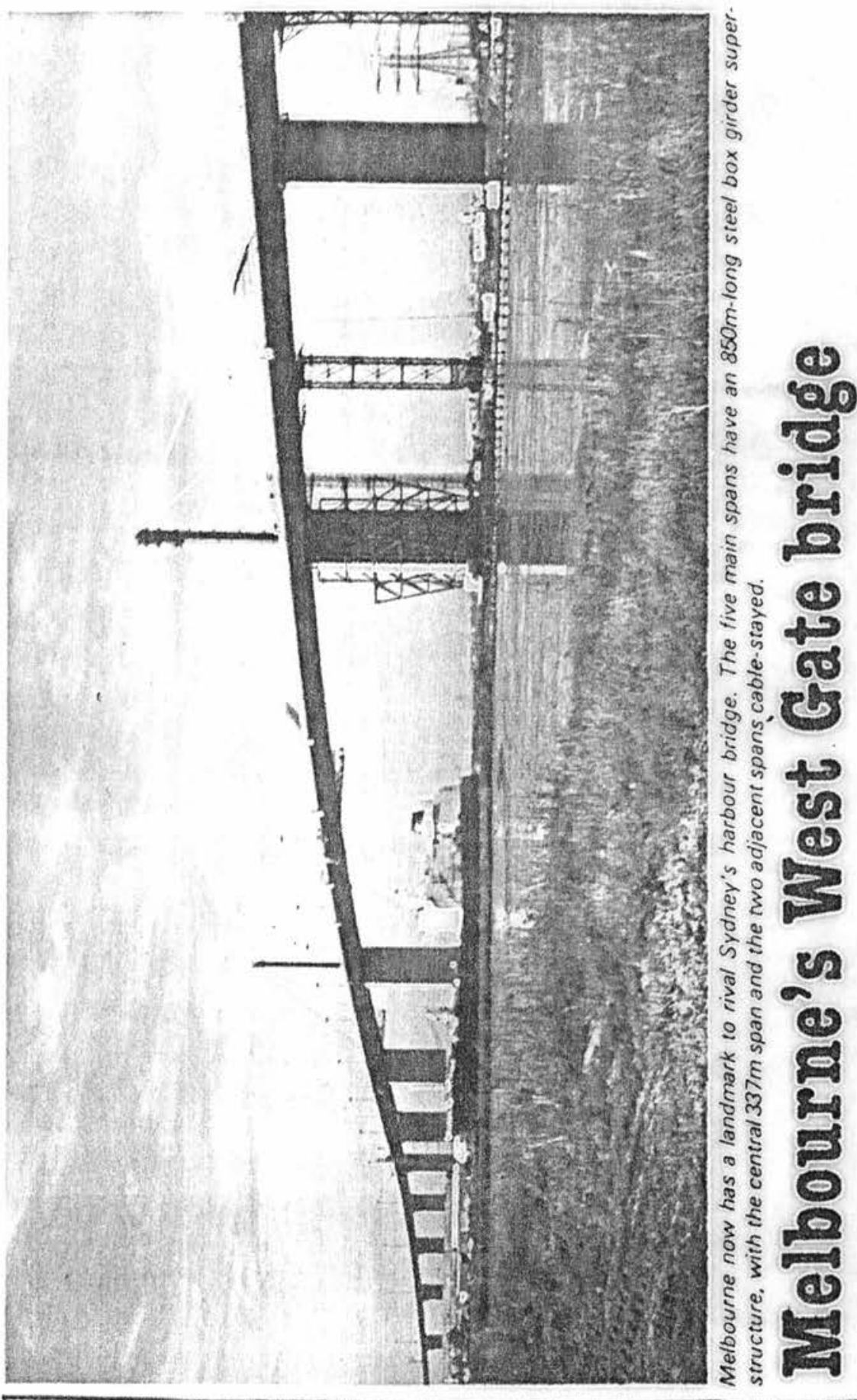




\section{Canada}

\subsection{British Columbia}

The Workers' Compensation Board is responsible for the administration of the Workers' Compensation Act 1968. The Board consists of 5 members appointed by the Lieutenant-Governor in Council.

9.1.1 The Workers' Compensation Act 1968: The main purpose of the Act is to compensate workers and dependents by means of levies on employers.

Under the Act, the Board, through its officers is charged with the responsibility of inspecting places of employment and with issuing orders and directions specifying the means for the prevention of injuries and industrial diseases, for assisting and advising employers and employees in the development of industrial health and safety programmes, and for the education in industrial health and safety matters of persons employed in British Columbian industry. An employer and a union representative is entitled to be present when any inspection is carried out (s.60A). If a Corporation is prosecuted for an offence, the directors, managers and supervisors can also be proceeded against (s.65). Penalties on convictions are paid to the Board and become part of the Accident Fund (s.66). The Board is empowered to make regulations for safety and accident prevention.

9.1.2 The Industrial Health and Safety Regulations 1978: These regulations provide an up to date and comprehensive code covering most industrial undertakings. For construction work, there are special sections covering: Underwater Diving, Protective Equipment, Welding, Powder Actuated Tools, Electrical Systems, Mobile Equipment, Scaffolds, Asbestos, Excavations, Demolition, Work in Compressed Air, Explosives, Construction. Towers and Hoists, Material Hoists, Traffic Control, Cranes and Derricks, Pile Driving, and Window Cleaning.

The regulations include the following novel requirements:

Inspection reports are required to be posted at the place of employment (reg.2.14);

Employers must keep a copy of the regulations readily available at each place of employment for reference by all employees (reg.2.20). 
An industrial health and safety programme must be initiated and maintained by each employer having a workforce of 20 or more (reg.4.02);

Employers must initiate, immediately, an investigation into the cause of every accident (reg.6.04);

Employers must ensure that adequate direction and instruction, in the safe performance of their duties is given to workers (reg. 8.18).

\subsection{Alberta}

The Department of Labour administers the Occupational Health and Safety Act 1976. The philosophy of the Department is :

\footnotetext{
"All persons at work have a fundamental right to an. environment that neither damages their health nor imperils their safety. It is the joint and co-operative responsibility of government, employers and workers, to develop an awareness and sensitivity to occupational health and safety."
}

9.2.1 The Occupational Health and Safety Act (1976): This Act sets out in detail the responsibilities of employers, workers and the government. The 'employer' must ensure as far as it is reasonably practicable, the health and safety of his workers. Every 'supplier' must ensure, as far as it is reasonably practicable, that any tool, appliance or equipment that he supplies is in safe operating condition, and complies with the requisite standards. A 'principle contractor' must ensure, as far as it is reasonably practicable, that every employer and every worker performing work on a project complies with the Act (s.2). The Act requires the appointment of a Director of Occupational Health and Safety Inspection, a Director of Medical Services, a Director of Occupational Hygiene, Occupational Health and Safety Officers, and such other employees as may be necessary for the administration of the Act (s.3).

The Lieutenant Governor in Council is required to appoint an "Occupational Health and Safety Council" consisting of not more than 12 persons to advise the Minister on matters concerning the Act and regulations, and on matters concerning the health and safety of workers, and to hear appeals (s.4). 
The Minister may order that there be established at any work site a joint work site health and safety committee, consisting of representatives of the principal contractor, the employers and the workers to identify unsafe situations, and to establish and maintain educational programmes regarding the health and safety of workers on work sites (s.25).

The Director of Inspection may order a principal contractor or employer responsible for a work site to establish a code of practice specifying safe working procedures for that site, and this code must be posted in a location where it is conspicuous to the workers and other persons at the site $(s .26)$.

Workers must not carry out any work where there exists an imminent danger to the health or safety of himself or any other worker. "Imminent danger" is interpreted as a danger which is not normal for that occupation (s.27).

9.2.2 Offences and Penalties: Any person who contravenes the Act is guilty of an offence and is liable for a maximum fine of $\$ 10,000$ and 12 months imprisonment.

9.2.3 The Occupational Health and Safety Regulations 1976:

These Regulations are divided into 8 separate sets of regulations: First Aid, General Accident Prevention, Construction Safety, Petroleum and Natural Gas Supply, Lumbering Safety, Explosives Safety, Grain Elevators, and Joint Work Site Health and Safety Committees. These regulations provide full and comprehensive codes for most industries. However, the Department advises that the regulations are under review and new ones are being developed which should be finalised early in 1980.

\subsection{Saskatchewan.}

The Department of Labour administers the Occupational Health and Safety Act, 1977 , through the Occupational Health and Safety Division, which has a Chief Occupational Health Officer, 2 senior officers, and 11 officers. The staff are evenly distributed between the 2 major cities of Regina and Saskatoon. 
9.3.1 The Occupational Health and Safety Act, 1927: The 'employer' has the duty, to ensure, insofar as is reasonably practicable, the health, safety and welfare of all his workers and to comply with the Act (s.3). Every worker must also comply with the Act, and take reasonable care to protect the health and safety of himself and other workers (s.4). Self-employed persons are also required to comply with the Act and to ensure insofar as is reasonably practicable, that he, and workers employed on or about the same place of employment who may be affected by the undertaking, are not exposed to risks (s.5).

The Lieutenant Governor in Council is required to appoint an Occupational Health and Safety Council of between 9 and 12 members whose particular knowledge and experience assists in advising the Minister on matters relating to the protection. and promotion of the health and safety of persons at work (s.10).

For the purpose of providing practical guidance, the director, after consultation with interested persons, may approve and issue codes of practice, which are published in the 'Gazette'. The failure by a person to observe the codes is not of itself an offence but where a person is charged with a breach, the code is admissable as evidence as a violation of a regulation (s.14).

Where 10 or more workers are employed, the employer must establish an Occupational Health Committee of between 2 and 12 persons, half of whom must be worker representatives. The principal duties of the committees are to identify and control health and safety hazards and to establish and promote programmes for education and information of the workers (s.24). 9.3.2 Offences and Penalties: Every person who contravenes the Act is guilty of an offence and is liable to a maximum fine of $\$ 10,000$ and $\$ 1,000$ per day for a continuing offence, and 2 years imprisonment (ss.32 \& 33). Where a corporation commits an offence, an officer, director, manager or agent of the corporation who directed, authorised or participated in the commission of the offence is liable on summary conviction to a penalty whether or not the corporation has been. prosecuted $(\mathrm{s} \cdot 34)$. 
In any proceedings for an offence consisting of a failure to comply with a duty or requirement to do something, so far as is practicable, or so far as is reasonably practicable, or to use the best practicable means to do something, it shall be for the accused to prove, that it was not practicable, or not reasonably practicable to do more than was actually done to satisfy the duty or requirement (s.35).

on average 15 prosecutions are taken each year, and the penalties range from $\$ 1,000$ to $\$ 50$.

There is no direct charge for any of the health and safety inspections carried out, but the Workers' Compensation Board pays the costs of the industrial safety and research programmes.

Regulations made under the Act provide a comprehensive code for most industries, including construction. 9.4 Manitoba

9.4.1 The Workplace Safety and Health Act 1976: This Act is administered by the Workplace Safety and Health Division of the Department of Labour and Manpower, and its object is to secure workers, self-employed and other persons from risks to their safety, health and welfare arising out of, or in. connection with, activities in their workplaces, and the promotion and maintenance of the highest degree of physical, mental and social well-being of workers (s.2).

Every employer must ensure, so far as is reasonably practicable, the safety, health and welfare at work of all his workers and must comply with the Act (s.4). Every worker, and self-employed person, must take reasonable care to protect his and other persons' safety and health, and comply with the Act (ss.5 \& 6). Every principal contractor engaged in a project must ensure, so far as it is reasonably practicable, that every employer, worker, and self-employed person performing work in respect of that project complies with the Act (s.7).

Al1 expenses incurred in the administration of the Act including the salaries of inspectors and other staff are chargeable to the accident fund under the Workers' Compensation Act (s.11). 
The provisions for the Advisory Council, Codes of Practice, Offences and Penalties are similar to those in Saskatchewan.

9.4.2 The Regulation 204/27: made under the Act are not as detailed as some of the other Provinces but nevertheless provide sufficient safety requirements for all industries, including construction.

\subsection{Ontario}

The Ministry of Labour administers the Occupational Health and Safety Act, 1978. The Construction Safety Act, 1973 has been repealed.

9.5.1 The Occupational Health and Safety Act, 1978: Where the number of workers at a project regularly exceeds 20 the 'constructor' must see that the workers select a health and safety representative who may inspect the physical condition. of the work place and identify situations that may be a source of danger or hazard to workers (s.7). Also when the workers exceed 20 the 'employer' must see that a joint health and safety committee is established consisting of at least 2 persons, of whom at least half shall be workers, to identify hazardous situations and to make recommendations to the 'constructor' or the 'employer' (s.8).

The Lieutenant Governor in Council on the recommendation of the Minister is required to appoint an Advisory Council on Occupational Health and Safety composed of between 12 and 20 members, and representative of management, labour, technical or professional persons, and the public who are concerned with and have knowledge of occupational health and safety. The function of the Council is to make recommendations and to advise the Minister (s.10).

The Lieutenant Governor in Council may also fix an amount that shall be assessed and levied by the Workmen's Compensation Board upon employers to defray the expenses of the administration of the Act.

The amount must not exceed $\$ 4,000,000$ each year, and increases by 10 per cent each year (s.12).

A 'constructor' must ensure, on a project, that the Act is complied with and that employers and workers on the project also comply (s.13). Every employer is also required to see 
that the Act is complied with (ss.14 \& 15), each supervisor must ensure that workers under his control comply (s.16), and each worker must himself comply (s.17). An owner of a work place that is not a project must also comply (s.18).

Every person who supplies any machine, device, tool or equipment under any rental, leasing or similar arrangement for use in or about a work place must ensure that the machine etc. is in good condition and complies with the Act (s.19). 9.5.2 Offences and Penalties: Every person who contravenes the Act is guilty of an offence and on summary conviction is liable to a fine of up to $\$ 25,000$ or to 12 months imprisonment, or both. In a prosecution of an offence, any act or neglect on the part of any manager, agent, representative, officer, director or supervisor of the accused, whether a corporation or not, shall be the act or neglect of the accused (s.37).

An information may at the election of the informant, be heard, tried and determined by the Provincial Court having jurisdiction in the county or district in which the accused is resident or carries on business although the subject-matter of the information did not arise in that county or district (s.39).

New regulations under this new Act are currently under review but in the meantime, Regulation 127 made under the Construction Safety Act 1973 provide the detailed safety requirements for the construction industry.

The Act is the most relevant of the Canadian Provinces for providing a statutory framework for consideration when the New Zealand legislation is being consolidated. The Ontario Act is reproduced as Appendix E.

\subsection{Quebec}

9.6.1 The Industrial and Commercial Establishments Act 1964: This Act is administered in the Department of Labour and governs all industries and commercial establishments, except for mines. As well as covering the safety of employees, this Act deals with sanitary conditions, hours of work, duties of employers, and inspection procedures.

9.6.2 Offences and Penalties: A person who keeps an industrial or commercial establishment contrary to the provisions of the Act is guilty of an offence and liable to a penalty of up to $\$ 6,000(\mathrm{~s} .30)$. If any offence is committed for which an 
employer is legally responsible and it appears to the satisfaction of the court that the offence has been committed without his personal consent, concurrence or knowledge but by some other person the court may summon that person and he will be liable to the penalty provided for the offence instead of the employer (s.37). When an offence for which an employer is responsible has been committed by some agent, servant, workman, or other person, that person will be liable to the same fine, penalty and punishment as if he were the employer (s.39).

9.6.3 The Construction Safety Code 1924: The Code is made under the Act and is divided into 10 Divisions: Definitions, General Provisions, Construction Sites, Handling and Use of Explosives, Work in Proximity of Electrical Lines, Shoring of Concrete Formwork, Use of Explosive Actuated Tools, Underground Work Sites, Works in Compressed Air, and Works on Streets, Roads and Highways. The Code is a clear, concise, modern and well presented document.

9.7 New Brunswick

9.7.1 The Occupational_Safety Act 1976: The Minister of Labour and Manpower has the responsibility for the general administration of the Act (s.2), and the Lieutenant-Governor in Council appoints the occupational safety officers including the Chief Safety officer (s.4).

Every contractor must comply with the Act and take every reasonable precaution to ensure the health and safety of any person having access to a project site (s.5). Subcontractors and employers are required to comply with the Act with respect to a project site, or part over which he has charge and control, and must take every reasonable precaution to ensure the health and safety of any person having access to the site over which he has control (ss.6 \& 7). Every employee must comply with the Act, and every employer and every person. with authority over an employee must ensure that the employee complies (s.8).

Where an employee is injured in a manner that causes or may cause, a fatality, or loss of limb, or that requires or may require hospitalisation, the employer must ensure that 
notice of the accident is sent to the Chief Safety Officer by telephone, telegraph or other suitable means, immediately, after the occurrence and a report must be made to the Chief Safety officer, once each month, with respect to all other injuries (s.16).

9.7.2 Offences and Penalties: A person who contravenes or fails to comply with the Act commits an offence and is liable on summary conviction to a fine of not less than $\$ 100$ and not more than $\$ 5,000$ for each day the offence continues, and in default of payment to imprisonment in accordance with the Summary Convictions Act.

9.7.3 The Occupational Safety Code 1278: Every place of employment is required to have readily available a copy of the Act and the regulations reg.3(1). The regulations may be deviated from in cases of practical difficulty or unnecessary hardship when it is evident that reasonable safety is assured and written permission has been obtained from the Chief Safety officer reg.3(2).

Included in the Code are the following interesting and novel provisions:

A representative of the employees may accompany an officer during an inspection of a place of employment, reg.3(3). When an inspection is made at the request of an employee he receives a copy of the special inspection report, reg.3(4).

Employers with less than 20 employees are required to establish and enforce an approved safety policy which must include general safety practices, reg.3(5).

Employers with 20 or more employees must establish and enforce an approved safety policy requiring the establishment of a safety committee consisting of equal representation from employers and employees. The Committee must meet at least once a month and carry out safety inspections on a regular basis, reg. $3(6)$.

Employers must ensure that each employee, before commencing any work, is properly trained in the duties of his work and in safe procedures, reg.3(7).

Separate Parts of the Code govern: Ladders, Scaffolds, Handling of Explosives, Excavations and Trenches, Hoisting Machinery and Apparatus, Construction Equipment, Electrical, Work in Compressed Air, Underwater Diving, and General 
Safety Practices.

\subsection{Nova Scotia}

9.8.1 The Construction Safety Act 1972: This Act is administered in the Department of Labour, and it requires the constructor to assume the overall responsibility for project safety. A subcontractor has a responsibility for the safety of all persons on the part or parts of a project under his direct control. The Minister is charged with the general administration and he appoints the inspectors including the Chief Inspector (ss.5 \& 6). 9.8.2 Offences and Penalties: Every person on a project who by his conduct wilfully endangers his safety, or that of other persons, or fails to use or wear protective devices, or clothing, when required by the constructor is guilty of an offence, and on summary conviction is liable to a maximum fine of $\$ 1,000$ and to 12 months imprisonment. Where a corporation. is convicted of an offence the maximum penalty is $\$ 5,000$ (s.19). The consent of the Minister is required before commencing a prosecution (s.20).

9.8.3 The Construction Safety Regulations 1972: Employers must provide and maintain a copy of the Act and the Regulations in a location readily accessible to the workmen, reg.3.

A regulation may be modified by the Chief Inspector where it is evident that a particular type of structure does not lend itself to a strict interpretation of a regulation. In all cases a minimum acceptable safety standard shall be the basis of any modification.

The technical regulations are divided in 40 Parts and provide a comprehensive code of safety requirements for construction work.

\subsection{Newfoundland and Labrador}

9.9.1 The Workmen's Compensation Act 1970: This Act is administered by the Workmen's Compensation Board and it provides a comprehensive compensation scheme and includes regulation-making powers for accident prevention.

\subsubsection{The Accident Prevention Regulations 1977: These}

Regulations cover all industries except mining and they are set out under 31 Parts including; Scaffolds, Ladders, Electrical, 
Explosive Actuated Tools, Construction Towers and Joists, Mechanical Plant, Mobile Equipment, Cranes, Derricks, Hoists, Pile Drivers, Rigging, Construction Procedures, Demolition, Excavations, and Explosives.

The Board may alter any regulation when the conditions, or the place of employment requires a variation (reg.2.02). Any contravention of the regulations by a supervisor or workman is deemed to be a contravention by the employer (reg.2.07), and likewise a contravention by a workman is deemed to be a contravention by the supervisor (reg.2.08).

The employer must ensure that his premises, methods and practices are safe, and that every workman uses the necessary safeguards (reg. 3.01). A supervisor is responsible for the proper instruction of workmen under his direction, and control, and for ensuring that work can be performed without undue risk (reg. 3.02). Every workman must comply with all safety provisions and instructions and report any hazards to his employer or supervisor (reg.3.03).

Persons are not permitted to engage in "horseplay", scuffling, unnecessary running or jumping, practical jokes, or any other similar activity or behaviour that might create or constitute a hazard to any workmen (reg.4.04).

An accident prevention programme must be initiated and maintained by each employer having a work force of 20 or more workmen. Where there is an overlapping of the work areas of 2 or more employers the principal contractor must set up and ensure the continuing function of a central management group to co-ordinate the accident prevention activities of the several employers. Each employer is to be represented and is to co-operate with the group (reg.5.01).

9.9.3 Offences and Penalty: Every person who contravenes the regulations is guilty of an offence and is liable to a penalty of between $\$ 100$ and $\$ 2,000$ (reg.2.10).

\subsection{Prince Edward Island}

Industrial safety is the responsibility of the Workers' Compensation Board under the Workers Compensation Act 1974. 
9.10.1 The Industrial Safety Regulations 1979: These

Regulations are applicable to all industries within the scope of the Act and they are set out under 26 sections including: Sanitation and Accommodation, Ventilation, Illumination, First Aid, Personal Protectịve Equipment, Chains and Slings, Wire Rope, Explosive-Actuated Tools, Ladders, Scaffolds, Electrical Construction Equipment, Excavations, Handling of Explosives and Mechanical Safety. 


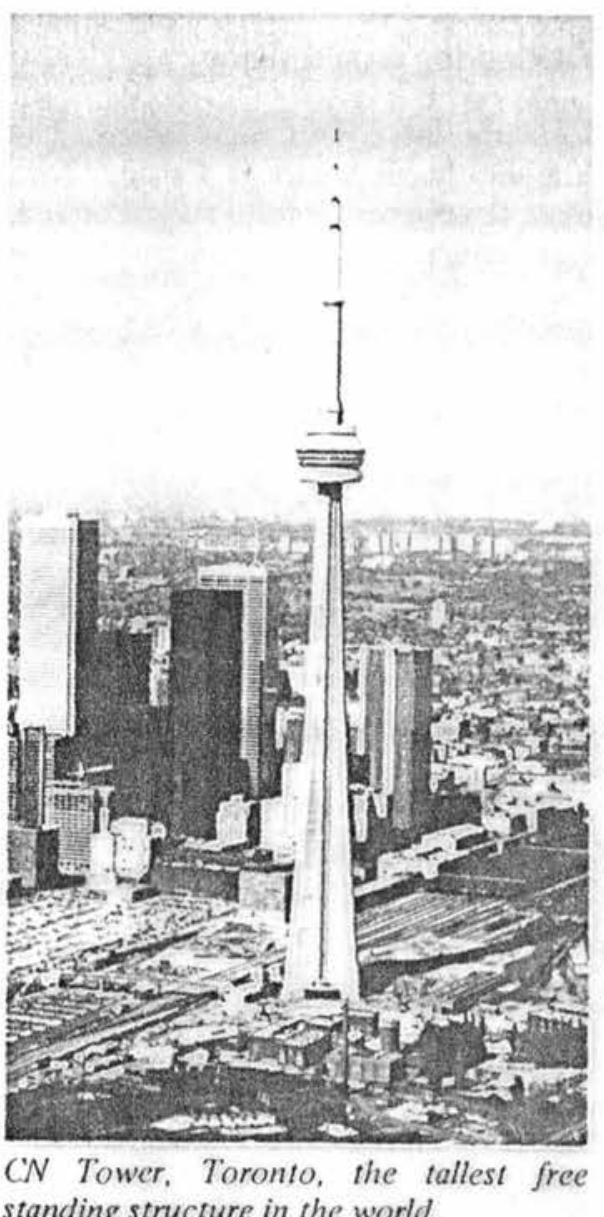




\begin{tabular}{|c|c|c|c|c|c|c|}
\hline $\begin{array}{l}\text { STATE OR } \\
\text { PROVINCE }\end{array}$ & $\begin{array}{l}\text { PERSON PRIMARILY } \\
\text { RESPONS IBLE }\end{array}$ & $\begin{array}{l}\text { OTHER PERSONS } \\
\text { RESPONSIBLE }\end{array}$ & $\begin{array}{l}\text { PERSON CREATING } \\
\text { OFFENCE }\end{array}$ & $\begin{array}{l}\text { PERSON WHO } \\
\text { LAYS CHARGE }\end{array}$ & $\begin{array}{l}\text { MAXIMUM } \\
\text { PENALTY }\end{array}$ & NAME OF ACT \\
\hline BRITAIN & Employer & $\begin{array}{l}\text { Employees } \\
\text { Contractors }\end{array}$ & $\begin{array}{l}\text { A person who } \\
\text { contravenes }\end{array}$ & $\begin{array}{l}\text { An inspector } \\
\text { or any person } \\
\text { with consent } \\
\text { of the D.P.P. }\end{array}$ & $\begin{array}{l}£ 1,000 \\
\& \\
12 \text { mths }\end{array}$ & $\begin{array}{l}\text { Health \& Safety } \\
\text { at Work etc. } \\
\text { Act } 1974\end{array}$ \\
\hline WEST AUSTRALIA & Main Contractor & $\begin{array}{l}\text { Sub-contractor } \\
\text { employer, } \\
\text { workman }\end{array}$ & $\begin{array}{l}\text { A person who } \\
\text { contravenes }\end{array}$ & $\begin{array}{l}\text { Any person } \\
\text { with the } \\
\text { consent of } \\
\text { Chief Insp. }\end{array}$ & $\$ 400$ & $\begin{array}{l}\text { Construction } \\
\text { Safety Act } 1972\end{array}$ \\
\hline SOUTH AUSTRALIA & $\begin{array}{l}\text { Employer, } \\
\text { Constructor }\end{array}$ & Worker & $\begin{array}{l}\text { Any person } \\
\text { (implied) }\end{array}$ & $\begin{array}{l}\text { Any } \\
\text { person. }\end{array}$ & $\$ 1,000$ & $\begin{array}{l}\text { Ind. Saf, Health } \\
\text { \& Welfare Act } \\
1972\end{array}$ \\
\hline VICTORIA & Contractor & & $\begin{array}{l}\text { Every person } \\
\text { who contravenes }\end{array}$ & Any person & $\$ 1,000$ & $\begin{array}{l}\text { Scaffolding } \\
\text { Act } 1971\end{array}$ \\
\hline QUEENSLAND & Constructor & $\begin{array}{l}\text { Sub-contractor } \\
\text { employer, } \\
\text { workman. }\end{array}$ & $\begin{array}{l}\text { A person who } \\
\text { contravenes }\end{array}$ & $\begin{array}{l}\text { Chief Insp. } \\
\text { or person } \\
\text { auth. by him, } \\
\text { or by the } \\
\text { Minister }\end{array}$ & $\$ 5,000$ & $\begin{array}{l}\text { Construction } \\
\text { Safety Act } 1971\end{array}$ \\
\hline TASMANIA & $\begin{array}{l}\text { Person carrying } \\
\text { on industry }\end{array}$ & Employees & $\begin{array}{l}\text { A person who } \\
\text { contravenes }\end{array}$ & Any person & $\$ 5,000$ & $\begin{array}{l}\text { Ind. Saf. Health } \\
\text { \& Welfare Act } \\
1974\end{array}$ \\
\hline NEW SOUTH WALES & Every person & & $\begin{array}{l}\text { Any person who } \\
\text { contravenes }\end{array}$ & Any person & $\$ 400$ & $\begin{array}{l}\text { Construction } \\
\text { Safety Act } 1912\end{array}$ \\
\hline BRITISH COLUMBIA & Employer & $\begin{array}{l}\text { Supervisors, } \\
\text { workers \& } \\
\text { any person. }\end{array}$ & $\begin{array}{l}\text { Any person who } \\
\text { contravenes }\end{array}$ & $\begin{array}{l}\text { Workers Comp. } \\
\text { Board }\end{array}$ & $\$ 1,000$ & $\begin{array}{l}\text { Workers Comp. } \\
\text { Act } 1968\end{array}$ \\
\hline ALBERTA & Employer & $\begin{array}{l}\text { Principal } \\
\text { contractor, } \\
\text { worker, } \\
\text { supplier }\end{array}$ & $\begin{array}{l}\text { Any person who } \\
\text { contravenes }\end{array}$ & Any person & $\begin{array}{l}\$ 10,000 \\
\& 4 \\
24 \text { mths }\end{array}$ & $\begin{array}{l}\text { Occupational } \\
\text { Health \& Saf. } \\
\text { Act } 1976\end{array}$ \\
\hline
\end{tabular}




\begin{tabular}{|c|c|c|c|c|c|c|}
\hline $\begin{array}{l}\text { STATE OR } \\
\text { PROVINCE }\end{array}$ & $\begin{array}{l}\text { PERSON PRIMARILY } \\
\text { RESPONSIBLE }\end{array}$ & $\begin{array}{l}\text { OTHER PERSONS } \\
\text { RESPONSIBLE }\end{array}$ & $\begin{array}{l}\text { PERSON CREATING } \\
\text { OFFENCE }\end{array}$ & $\begin{array}{l}\text { PERSON WHO } \\
\text { LAYS CHARGE }\end{array}$ & $\begin{array}{l}\text { MAXIMUM } \\
\text { PENALTY }\end{array}$ & NAME OF ACT \\
\hline SASKATCHEWAN & Employer & $\begin{array}{l}\text { Workers, } \\
\text { self-employed }\end{array}$ & $\begin{array}{l}\text { Every person who } \\
\text { contravenes }\end{array}$ & Any person & $\begin{array}{l}\$ 10,000 \& \\
24 \text { mths }\end{array}$ & $\begin{array}{l}\text { Occupational } \\
\text { Health \& Safety } \\
\text { Act } 197 ?\end{array}$ \\
\hline MANITOBA & Employer & $\begin{array}{l}\text { Workers, self- } \\
\text { employed, } \\
\text { principal } \\
\text { contractor }\end{array}$ & $\begin{array}{l}\text { Every person who } \\
\text { contravenes }\end{array}$ & Any person & $\begin{array}{l}\$ 10,000 \& \\
6 \text { mths }\end{array}$ & $\begin{array}{l}\text { Workplace Safety } \\
\text { \& Health Act } \\
1976\end{array}$ \\
\hline ONTARIO & Constructor & $\begin{array}{l}\text { Employer, } \\
\text { supervisor, } \\
\text { worker }\end{array}$ & $\begin{array}{l}\text { Any person who } \\
\text { contravenes }\end{array}$ & Any person & $\begin{array}{l}\$ 25,000 \& \\
12 \text { mths }\end{array}$ & $\begin{array}{l}\text { Occupational } \\
\text { Health \& Safety } \\
\text { Act } 1978\end{array}$ \\
\hline QUEBEC & Employer & & Every person & $\begin{array}{l}\text { Inspector or } \\
\text { person } \\
\text { designated by } \\
\text { Minister }\end{array}$ & $\$ 6,000$ & $\begin{array}{l}\text { Industrial \& } \\
\text { Commercial } \\
\text { Establishments } \\
\text { Act } 1964\end{array}$ \\
\hline NEW BRUNSWICK & Contractor & $\begin{array}{l}\text { Sub-contractor, } \\
\text { employer, } \\
\text { employee }\end{array}$ & $\begin{array}{l}\text { A person who } \\
\text { contravenes }\end{array}$ & Any person & $\begin{array}{l}\$ 5,000 \& \\
12 \text { mths }\end{array}$ & $\begin{array}{l}\text { Occupational } \\
\text { Safety Act } 1976\end{array}$ \\
\hline NOVA SCOTIA & Constructor & Sub-contractor & $\begin{array}{l}\text { Every person } \\
\text { who contravenes }\end{array}$ & $\begin{array}{l}\text { Any person } \\
\text { with consent } \\
\text { of Minister }\end{array}$ & $\begin{array}{l}\$ 5,000 \& \\
12 \text { mths }\end{array}$ & $\begin{array}{l}\text { Construction } \\
\text { Safety Act } 1972\end{array}$ \\
\hline $\begin{array}{l}\text { NEWF OUNDLAND/ } \\
\text { LABRADOR }\end{array}$ & Employer & $\begin{array}{l}\text { Supervisor } \\
\text { Workman }\end{array}$ & $\begin{array}{l}\text { Every person } \\
\text { who contravenes }\end{array}$ & Any person & & $\begin{array}{l}\text { Workmans } \\
\text { Compensation Act }\end{array}$ \\
\hline
\end{tabular}

